\title{
Oligocene-Miocene scleractinians from the Central Indo-Pacific: Malaysian Borneo and the Philippines
}

\author{
Morana Mihaljević
}

\begin{abstract}
A new fossil coral collection enhances our understanding of scleractinian coral diversity during the origination of the Indo-Pacific biodiversity hotspot (Oligocene - earliest Miocene). The fossil corals were collected from Sarawak (Malaysia), Negros and Cebu (the Philippines). The oldest fossil specimens are from Cebu, found in the Calagasan Formation (late Oligocene - middle Chattian) and Butong Limestone (late Oligocene - late Chattian). The specimens from the Trankalan/Binaguiohan (Negros), Melinau and Subis Limestone (Sarawak) are all of early Miocene (Aquitanian) age. Forty-four morphospecies belonging to 30 genera were identified, and detailed taxonomic descriptions are provided. These data extend the temporal ranges of six coral genera (Acanthastrea, Astrea, Blastomussa, Coelastrea, Lobophyllia, Paramontastraea). By expanding our knowledge of scleractinian coral diversity and morphological variation in the Central Indo-Pacific, this new fossil collection provides important background for future studies of coral taxonomy, diversity and biogeography in the region.
\end{abstract}

Morana Mihaljević. School of Earth and Environmental Sciences, The University of Queensland, Brisbane, Queensland 4072, Australia and Science Lab UZH, Univesity of Zurich, 8057 Zurich, Switzerland. m.mihaljevic@uq.edu.au

Keywords: new collection; fossil corals; biodiversity hotspot; origin

Submission: 4 March 2019. Acceptance: 14 August 2019.

\section{INTRODUCTION}

The Central Indo-Pacific region (here defined as $20^{\circ} \mathrm{S}-20^{\circ} \mathrm{N}, 90^{\circ}-180^{\circ} \mathrm{E}$ ) is a hotspot of modern marine biodiversity (Rosen, 1981; Barber, 2009; Bellwood and Renema, 2012), and it has been one for $\sim 28$ My (Mihaljević et al., 2017). Throughout its history, the Central Indo-Pacific biodiversity hotspot has contained an exceptionally high diversity of scleractinian corals. At present it comprises over one-half of the world's coral reef systems with more than 500 known scleractinian coral species (Veron, 2000; Veron et al., 2009). This hotspot,

Mihaljević, Morana. 2019. Oligocene-Miocene scleractinians from the Central Indo-Pacific: Malaysian Borneo and the Philippines. Palaeontologia Electronica 22.3.61 1-55. https://doi.org/10.26879/978 palaeo-electronica.org/content/2019/2715-oligocene-miocene-corals 
however, is not the only one known during the Cenozoic. The high diversity of corals (Wallace and Rosen, 2006) as well as foraminifera (Renema et al., 2008), mollusks (Kay, 1996) and mangroves (Ellison et al., 1999; Morley, 2000) shifted from the West Tethyan marine biodiversity hotspot (middle Eocene and older) across to the Arabian hotspot (late Eocene - early Miocene) to the Central IndoPacific region where it was well established by the early Miocene.

The mechanisms underlying the origin of the Central Indo-Pacific marine biodiversity hotspot are still highly debated (Hoeksema, 2007). There are three main competing models: (1) the Centre of Origin, (2) the Centre of Accumulation and (3) the Centre of Survival models. The Centre of Origin, or cradle model, implies high origination rates within the hotspot compared with the surrounding regions (Ekman, 1953; Stehli and Wells, 1971; Rosen, 1984, 1985; Briggs, 1992). The Centre of Accumulation, or museum model, assumes high immigration rates within the hotspot resulting in the increase of diversity in the hotspot over time (Ladd, 1960; Rosen, 1984, 1988; Jokiel and Martinelli, 1992; Pandolfi, 1992; Kay, 1996; Wallace, 1997). The Centre of Survival, or refuge model, is characterized by high extinction rates in areas surrounding the hotspot (McCoy and Heck, 1976; Paulay, 1997). Survival (low extinction rate) within the hotspot is explained by its high level of habitat diversity, enabling the sustainability of high diversity (Barber and Bellwood, 2005; Bellwood and Meyer, 2009). However, a recent study based on empirical data shows that origination and persistence of the Indo-Pacific marine biodiversity hotspot is more complex (Cowman and Bellwood, 2011) and supports what many authors have previously suggested - that a single model is not sufficient to explain such a challenging issue (Rosen, 1984; Palumbi, 1997; Bellwood and Wainwright, 2002; Barber and Bellwood, 2005; Bellwood and Renema, 2012). The interplay between origination/ extinction events and habitat seems to be fundamental for understanding the exceptionally high diversity in the Indo-Pacific region, given that high habitat diversity is essential for the accommodation of high faunal diversity in any biodiversity hotspot model (Simpson, 1949; MacArthur and MacArthur, 1961; Tews et al., 2004). Structural complexity of habitats is increased by the presence of reef-building corals whose skeletons provide a three-dimensional framework that promotes marine organism diversity and coexistence (Roberts and Ormond, 1987; Tokeshi and Arakaki, 2011; Dustan et al.,
2013). Coral reefs seem to drive diversification (Cowman et al., 2009; Bellwood et al., 2010; Price et al., 2010) and potentially facilitate vicariance events (Alfaro et al., 2007; Bellwood et al., 2010). Additionally, coral reefs appear to serve as refuge by reducing vulnerability to extinction (Cowman and Bellwood, 2011). Therefore, the Central IndoPacific with its extensive coral reefs seems to serve simultaneously as a center of origination, accumulation and survival.

New fossil collections, such as those studied herein, are crucial for uncovering evolutionary patterns of the Central Indo-Pacific corals because they provide empirical data for documenting past diversity and underlying ancestor-descendant relationships (Adrain, 2001; Jackson and Erwin, 2006). The value of fossil data for evolutionary studies depends on the quality and precision of taxonomic identifications (and descriptions) of new collections (Patterson, 1981; Hedges et al., 1996; Blair and Hedges, 2005). New fossil data can help calibrate molecular clocks by providing firm minimum age of diversification events and therefore assist in estimating diversification rates (Alfaro et al., 2007; Benton and Emerson, 2007; Donoghue and Benton, 2007; Simpson et al., 2011). Understanding paleontological longevity and distribution of taxa supplements our knowledge of present-day distributions in our attempt to predict future diversities and distributions (Keith et al., 2013). Accuracy of probabilistic models of taxonomic distribution and population connectivity can be enhanced by the inclusion of robust fossil data (Belasky, 1996; Palumbi, 1997). Hence, the synergy of interdisciplinary approaches (Jackson and Erwin, 2006; Donoghue and Benton, 2007), founded on new fossil collections, gathered in a rigorous temporal and environmental framework (Jackson and Johnson, 2000), is a reliable way forward in studying the evolution and longevity of the tropical marine fauna in the Central Indo-Pacific. Such interdisciplinary approaches may help reveal the drivers and underlying mechanisms that explain the origin of the hotspot (Potts, 1983).

Initial geological surveys in the Central IndoPacific started in the nineteenth century by European explorers and petroleum companies and were conducted mostly in Indonesia. In addition to the production of geological maps, stratigraphic sections and detailed facies description, these early surveys generated unique fossil collections, which are now housed in museums across Europe (e.g., Leloux and Renema, 2007). As early as the second half of 19th century the first fossil coral 
descriptions and monographs were published (Duncan, 1863, 1864; Martin, 1879, 1883). Intensive discovery, collection and description of fossil corals continued until mid 20th century. The most notably fossil coral monographs by Felix (1913, 1915, 1921), Gerth (1921a, 1923, 1925) and Umbgrove $(1926,1929,1938,1939,1945,1946 a$, $1946 b, 1950)$ included detailed taxonomic descriptions and drawings and were accompanied by geologic locality information. By reporting and describing over 180 scleractinian species $(\sim 70$ genera), these early documents provide the foundation for our understanding of scleractinian evolution in the Central Indo-Pacific.

However, until as recently as 2010 only a few studies have systematically analyzed scleractinian diversity in the Central Indo-Pacific region (Umbgrove, 1946c; Wilson and Rosen, 1998). This changed with the creation of the Indo-Pacific Ancient Ecosystem Group (IPAEG, ipaeg.org), an international group of scientists that aims to document the relationship between environmental and biotic change on coral reefs and shallow tropical marine ecosystems in the Indo-West Pacific. Recent robust analyses of Central Indo-Pacific scleractinian diversity, accompanied by detailed taxonomic descriptions in line with modern scleractinian systematics and nomenclature (Bromfield, 2013; Santodomingo et al., 2015a), show that high regional diversity of corals was already established by the late early Miocene (Burdigalian) and was driven by local environmental factors (Bromfield and Pandolfi, 2011; Johnson et al., 2015; Santodomingo et al., 2016). Increases in the availability and diversity of habitats triggered by tectonic movements were identified as the main drivers that led to this diversification and proliferation of corals (Wilson and Rosen, 1998; Renema et al., 2008; Mihaljević et al., 2014). However, our knowledge of scleractinian evolution prior to the Burdigalian, during the origination of the Central Indo-Pacific biodiversity hotspot, is still sparse; so much so that Wilson and Rosen (1998) referred to the paucity of Paleogene fossil corals as the "Paleogene gap". This scarcity of corals, however, appears to relate more to low abundance of scleractinians in the fossil record rather than to low diversity (Wilson, 2008). The Eocene fossil record of Central IndoPacific scleractinians comprises 30 genera of which 23 are known from Indonesia (Martin, 1879; Gerth, 1921a, 1933; Umbgrove, 1943; Wilson and Rosen, 1998) and 11 from Papua New Guinea (Gregory and Trench, 1916). Until recently, only eight genera were known from the Oligocene: seven from Indonesia (Osberger, 1955; Cornée et al., 2002) and a single genus from Myanmar (Vredenburg, 1921). Recent studies of Oligocene deposits in Sabah, Malaysia led to the description of 51 additional genera (McMonagle et al., 2011; McMonagle, 2012).

These recent detailed taxonomic descriptions of Indo-Pacific scleractinians throughout their evolutionary history are crucial for understanding the origin and persistence of the Central Indo-Pacific marine biodiversity hotspot, but important gaps remain. Hence, I describe new fossil coral collections from Sarawak (Malaysia), Negros and Cebu (the Philippines) representative of the development of the hotspot from the late Oligocene (Chattian) and earliest Miocene (Aquitanian). By expanding our collection of corals of these ages, this collection contributes greatly to our understanding of the initial development of the Central Indo-Pacific marine biodiversity hotspot (Mihaljević et al., 2017).

\section{MATERIALS AND METHODS}

\section{Study Sites and Collection}

Fossil corals were collected from five geological formations from three areas within the Central Indo-Pacific: Sarawak in Malaysia and the islands of Negros and Cebu in the Philippines (Figure 1). Study localities were selected based on reported ages (Oligocene and earliest Miocene), previous locality descriptions, fossil coral abundance and preservation quality (Table 1) (Barnes et al., 1958; Adams and Haak, 1962; Adams, 1965; Porth and Daniels, 1989; Jurgan and Domingo, 1989; Wannier, 2009; Aurelio and Peña, 2010). To capture the range of sedimentary environments and coral reef habitats, both limestone and shale formations/lithologies were sampled strategically. Stratigraphic ranges of geologic sections from the study sites were determined using occurrences of large benthic foraminifera (Lunt and Allan, 2004; Lunt and Renema, 2014; Mihaljević et al., 2017). In Sarawak, the Melinau (early Miocene: Aquitanian) and the Subis (early Miocene: Aquitanian) Limestones were studied, on Negros the Trankalan/Binaguiohan Limestone (early Miocene: Aquitanian), and on Cebu the Calagasan Formation (late Oligocene: middle Chattian) and the Butong Limestone Formation (late Oligocene: late Chattian). Fossil corals were collected stratigraphically from 14 outcrops (Table 2), which included both long stratigraphical sections in quarries and coral-rich beds exposed along road cuts. Sampling effort among sites was 

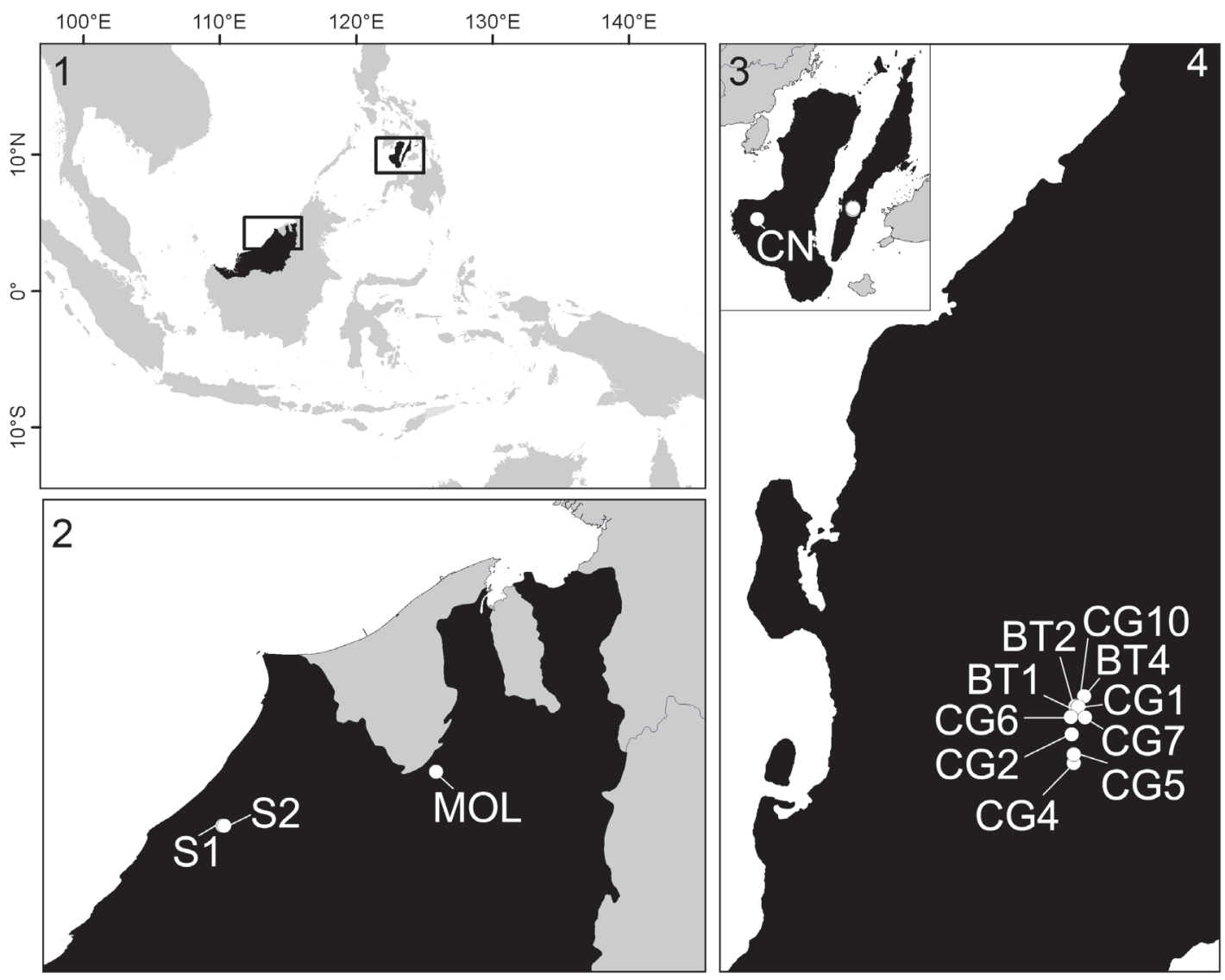

FIGURE 1. Map of sites where new fossil coral collections were made. 1) Map of the Central Indo-Pacific region with Sarawak, Negros and Cebu marked in black. The two rectangles border Sarawak (left), and Negros and Cebu (right). 2) Sarawak with two localities from the Subis Limestone (SL1 and SL2) and one locality from the Melinau Limestone (ML). 3) Close up of islands of Negros and Cebu in the Philippines. TBL locality from Negros in indicated. Black rectangle and white dot on in the southern part of Cebu mark general position of the localities shown in 4. 4) Map of the studied localities on Cebu: seven localities from the Calagasan Formation (CF1, CF2, CF4, CF5, CF6, CF7 and CF10) and three localities from the Butong Limestone Formation (BLF1, BLF2 and BLF4). From Mihaljević et al. 2017.

TABLE 1. Age, tectonic and depositional settings of studied geological formations. Modified from Mihaljević et al., 2017.

\begin{tabular}{|c|c|c|c|c|}
\hline Geological Formation & Age & Tectonic setting & Depositional setting & References \\
\hline $\begin{array}{l}\text { Butong Limestone } \\
\text { Formation (Cebu) }\end{array}$ & $\begin{array}{l}\text { late Oligocene-early } \\
\text { Miocene }\end{array}$ & $\begin{array}{l}\text { Backarc setting? Oblique } \\
\text { convergence }\end{array}$ & $\begin{array}{l}\text { Isolated low relief } \\
\text { buildups }\end{array}$ & $\begin{array}{l}\text { Porth et al., 1989; Wilson, } \\
\text { 2002; Aurelio and Peña, } \\
\text { 2010. }\end{array}$ \\
\hline $\begin{array}{l}\text { Calagasan Formation } \\
\text { (Cebu) }\end{array}$ & late Oligocene & $\begin{array}{l}\text { Overlying the Butong } \\
\text { Limestone }\end{array}$ & $\begin{array}{l}\text { Coral rich limestone } \\
\text { lenses within a shale }\end{array}$ & $\begin{array}{l}\text { Aurelio and Peña, 2010; } \\
\text { Mihaljević et al., } 2017\end{array}$ \\
\hline $\begin{array}{l}\text { Melinau Limestone } \\
\text { (Sarawak) }\end{array}$ & $\begin{array}{l}\text { Eocene - early } \\
\text { Miocene }\end{array}$ & $\begin{array}{l}\text { Isolated carbonate } \\
\text { platform, basin margin }\end{array}$ & $\begin{array}{l}\text { Carbonate platform, } \\
\text { some marginal deposits, } \\
\text { coral patch reefs only } \\
\text { noted in Miocene }\end{array}$ & $\begin{array}{l}\text { Adams and Haak, 1962; } \\
\text { Adams, 1965; Wannier, } \\
\text { 2009; Mihaljević et al., } \\
2014\end{array}$ \\
\hline $\begin{array}{l}\text { Subis Limestone } \\
\text { (Sarawak) }\end{array}$ & early Miocene & $\begin{array}{l}\text { Baram Balabac Basin } \\
\text { margin }\end{array}$ & $\begin{array}{l}\text { Isolated carbonate } \\
\text { platform formed on } \\
\text { palaeohigh }\end{array}$ & $\begin{array}{l}\text { Adams, 1965; Mihaljević } \\
\text { et al., } 2014\end{array}$ \\
\hline $\begin{array}{l}\text { Trankalan/Binaguiohan } \\
\text { Limestone (Negros) }\end{array}$ & $\begin{array}{l}\text { late Oligocene-early } \\
\text { Miocene }\end{array}$ & Unclear & $\begin{array}{l}\text { Carbonate platform with } \\
\text { localized patch reefs }\end{array}$ & $\begin{array}{l}\text { Jurgan and Domingo, } \\
\text { 1989; Porth et al., 1989; } \\
\text { Aurelio and Peña, } 2010\end{array}$ \\
\hline
\end{tabular}


TABLE 2. An overview of the fossil collection localities with geological formation, their age and latitude and longitude coordinates. From Mihaljević et al., 2017.

\begin{tabular}{|c|c|c|c|}
\hline Locality & Geological Formation & Age & Lat/long \\
\hline CF1 & Calagasan Formation & $\begin{array}{l}\text { late Oligocene } \\
\text { (middle Chattian) }\end{array}$ & $\begin{array}{l}\mathrm{N} 9^{\circ} 54^{\prime} 22.9^{\prime \prime} \\
\mathrm{E} 123^{\circ} 29^{\prime} 56^{\prime \prime}\end{array}$ \\
\hline CF2 & Calagasan Formation & $\begin{array}{l}\text { late Oligocene } \\
\text { (middle Chattian) }\end{array}$ & $\begin{array}{l}\text { N 9०53'42.3" } \\
\text { E } 123^{\circ} 29^{\prime} 46.2^{\prime \prime}\end{array}$ \\
\hline CF4 & Calagasan Formation & $\begin{array}{l}\text { late Oligocene } \\
\text { (middle Chattian) }\end{array}$ & $\begin{array}{c}\mathrm{N} 9^{\circ} 53^{\prime} 0.49^{\prime \prime} \\
\text { E } 123^{\circ} 29^{\prime} 49.33^{\prime \prime}\end{array}$ \\
\hline CF5 & Calagasan Formation & $\begin{array}{l}\text { late Oligocene } \\
\text { (middle Chattian) }\end{array}$ & $\begin{array}{l}\text { N 953'13.3" } \\
\text { E } 123^{\circ} 29^{\prime} 49.5^{\prime \prime}\end{array}$ \\
\hline CF6 & Calagasan Formation & $\begin{array}{l}\text { late Oligocene } \\
\text { (middle Chattian) }\end{array}$ & $\begin{array}{c}\mathrm{N} \mathrm{9} 54^{\circ} 7.4^{\prime \prime} \\
\text { E } 123^{\circ} 29^{\prime} 44.8^{\prime \prime}\end{array}$ \\
\hline CF7 & Calagasan Formation & $\begin{array}{l}\text { late Oligocene } \\
\text { (middle Chattian) }\end{array}$ & $\begin{array}{l}\text { N 9 } 9^{\circ} 54^{\prime} 7.1^{\prime \prime} \\
\text { E } 123^{\circ} 30^{\prime} 5.5^{\prime \prime}\end{array}$ \\
\hline CF10 & Calagasan Formation & $\begin{array}{l}\text { late Oligocene } \\
\text { (middle Chattian) }\end{array}$ & $\begin{array}{c}N 9^{\circ} 53^{\prime} 13^{\prime \prime} \\
\text { E } 123^{\circ} 29^{\prime} 49.75^{\prime \prime}\end{array}$ \\
\hline BLF1 & Butong Limestone Formation & $\begin{array}{l}\text { late Oligocene } \\
\text { (late Chattian) }\end{array}$ & $\begin{array}{c}\mathrm{N} \mathrm{9} 54^{\circ} 23.2^{\prime \prime} \\
\text { E } 123^{\circ} 29^{\prime} 51.5^{\prime \prime}\end{array}$ \\
\hline BLF2 & Butong Limestone Formation & $\begin{array}{l}\text { late Oligocene } \\
\text { (late Chattian) }\end{array}$ & $\begin{array}{l}\text { N 954'20.6" } \\
\text { E } 123^{\circ} 29^{\prime} 53.8^{\prime \prime}\end{array}$ \\
\hline BLF4 & Butong Limestone Formation & $\begin{array}{l}\text { late Oligocene } \\
\text { (late Chattian) }\end{array}$ & $\begin{array}{l}\text { N 9॰54'37.7" } \\
\text { E } 123^{\circ} 30^{\prime} 4 "\end{array}$ \\
\hline TBL & $\begin{array}{l}\text { Trankalan/Binaguiohan } \\
\text { Limestone }\end{array}$ & $\begin{array}{l}\text { early Miocene } \\
\text { (Aquitanian) }\end{array}$ & $\begin{array}{c}\mathrm{N} 9^{\circ} 48^{\prime} 7.89^{\prime \prime} \\
\text { E } 122^{\circ} 37^{\prime} 17.56^{\prime \prime}\end{array}$ \\
\hline ML & Melinau Limestone & $\begin{array}{l}\text { early Miocene } \\
\text { (Aquitanian) }\end{array}$ & $\begin{array}{l}\mathrm{N} 4^{\circ} 1^{\prime} 57.9^{\prime \prime} \\
\mathrm{E} 114^{\circ} 47^{\prime} 19^{\circ}\end{array}$ \\
\hline SL1 & Subis Limestone & $\begin{array}{l}\text { early Miocene } \\
\text { (Aquitanian) }\end{array}$ & $\begin{array}{l}\mathrm{N} 3^{\circ} 46^{\prime} 45.66^{\prime \prime} \\
\text { E } 113^{\circ} 46^{\prime} 50.95^{\prime \prime}\end{array}$ \\
\hline SL2 & Subis Limestone & $\begin{array}{l}\text { early Miocene } \\
\text { (Aquitanian) }\end{array}$ & $\begin{array}{c}\mathrm{N} 3^{\circ} 46^{\prime} 42.82^{\prime \prime} \\
\mathrm{E} 113^{\circ} 47^{\prime} 15.68^{\prime \prime}\end{array}$ \\
\hline
\end{tabular}

time-standardized based on lithology $(1 \mathrm{hr} /$ section for shale; 3hr/section for massive limestone) in order to account for the more difficult, time-consuming extraction of samples from more indurated massive limestones. For more details on sampling methods, stratigraphy and geologic setting, please refer to (Mihaljević et al., 2014, 2017).

\section{Fossil Material}

The new fossil coral collection comprises 1605 specimens, generating a total of 464 museum lots (Appendix 1). Multiple fragments found together forming a colony or in close proximity $(<20 \mathrm{~cm})$ were considered a single specimen lot, to which one catalogue number was assigned. All the examined specimens are reposited in the paleontological collections of the Queensland Museum in Brisbane, Australia.

The coral fragments extracted from the massive limestone were cut with a rock saw prior to analysis to expose diagnostic characters. Fragments from the shale lithologies were soaked in water, washed and air dried prior to taxonomic description. Samples were photographed using a Canon EOS 600D camera. Macro-photographs were taken using a Q-Imaging MicroPublisher 5.0RTV microscope camera. Photograph quality was enhanced by stacking multiple images of a specimen using Adobe Photoshop CS5.1.

\section{Taxonomic Identification}

Species identification of extant scleractinian corals was based on description of macro-morphological (e.g., colony shape, growth form, corallite arrangement and size, septal arrangement and columella type), micro-morphological (e.g., septal teeth structure and texture of the corallite surfaces) and micro-structural characters (e.g., calcification centers and crystal fiber arrangement) (Cuif and Perrin, 1999). Due to taphonomic alteration, especially recrystallization and in-filling, the micro-structural and some micro-morphological features are heavily altered in many specimens (Sorauf, 1980; Perrin, 2004). The high variability of coral morphol- 
ogy within a 'species' and even within a single colony (Veron and Pichon, 1976; Veron et al., 1977; Veron and Pichon, 1980, 1982; Veron and Wallace, 1984; Veron, 1995; Carpenter et al., 2008), as well as fragmentation of the specimens, further complicates taxonomic identification. Therefore, the fossil scleractinians described herein were divided into morphospecies based on macro-morphological characters and where possible species names were assigned. Species names assigned to the studied material correspond to species known from the Central Indo-Pacific fossil record. For morphospecies unknown from the fossil record and with less than five specimens, no formal name was given but distinction of the species was made with letters (e.g., sp. A, sp. B). To avoid further pollution of already challenging coral taxonomic literature, five specimens were set as a minimum needed to erect a new species among the highly taphonomically altered specimens described herein. To indicate that the species determination is uncertain due to preservation or other reasons discussed, where appropriate open nomenclature (cf.) based on Bengston (1988) was used. If morphological characters needed to distinguish between known fossil species were not preserved or if the studied material showed substantial variation in preservation, spp. was assigned to the studied material as it potentially represents multiple morphospecies. All spp. taxa are clearly different from other herein described species of that genus.

The macro-morphological characters used are described in the glossary of Budd and Stolarski (2009), supplemented by Veron and Stafford-Smith (2000), Budd et al. (2012), Wallace (1999), Kithara et al. (2012), Hoeksema (1989), where appropriate. In addition, paleontological literature on the Central Indo-Pacific coral fossil record (Gerth, 1921a, 1921b, 1923; Umbgrove, 1924; Gerth, 1925; Umbgrove, 1926, 1929, Gerth, 1931,1933; Umbgrove, 1938, 1939, 1942, 1943, 1945, 1946a, 1946b, 1946c, 1950; McMonagle, 2012), recently published monographs (Leloux and Renema, 2007; Bromfield, 2013) and a reference collection at the Queensland Museum were used to identify extinct fossil genera. Further coral identifications were made with the aid of the Neogene Marine Biota of Tropical America (NMITA) database (Budd et al., 2001) for fossil taxa and the Scleractinia of Eastern Australia, Parts 1-5 (Veron and Pichon, 1976; Veron et al., 1977; Veron and Pichon, 1980, 1982; Veron and Wallace, 1984), the Coral ID interactive key (Veron and Stafford-Smith, 2002) and three volumes of the Corals of the World (Veron,
2000) for extant taxa. The World Register of Marine Species (Hoeksema and Cairns, 2014) coupled with recent changes in taxonomic delineations (e.g., Huang et al., 2014) was used to check the current recognition of taxonomical nomenclature and classification and to provide an additional literature source for diagnostic features of extant families and genera. The Paleobiology Database (PBDB, paleobiodb.org) was used as an analogous resource of diagnostic features for fossil genera as well as for compiling occurrences and distributions of genera. Occurrence and distribution of Central Indo-Pacific genera were further cross-checked with recent literature (McMonagle, 2012; Bromfield, 2013; Santodomingo et al., 2016). Synonym lists provided reflect my opinions of taxonomic equivalency based on my direct inspection of type specimens and/or figured specimens from previously published works. Discussion of these synonymous genera/species and their morphological similarities to the newly described specimens are provided within the Remarks section for each taxon. Where appropriate, discussion of similar species and their morphological features are included.

\section{Statistical Analyses for Testing Coral Assemblage Distinctions}

To test if the dissimilarities between Chattian and Aquitanian sites were statistically significant, I used the nonparametric test ANOSIM (analysis of similarities) (Clarke, 1993; Pandolfi and Minchin, 1996). Additionally, a hierarchical cluster analysis was performed on the Bray-Curtis dissimilarity matrix showing the distinctions in taxonomic composition of coral communities. ANOSIM was also used to determine if there is a statistically significant difference in preservation of different coral colony shapes within the different lithologies (shale and limestone). The spp. taxa have also been included in these analysis as they contribute to capturing the diversity present in this new fossil collection and therewith in the Central Indo-Pacific. As these spp. taxa potentially represent multiple morphospecies the estimates of diversity and community composition are conservative. All statistical analyses were carried out using $\mathrm{R} 2.15 .2$ software (R Development Core Team, 2012).

\section{SYSTEMATIC PALEONTOLOGY}

Phylum CNIDARIA Hatscheck, 1888 Class ANTHOZOA Ehrenberg, 1834

Subclass HEXACORALLIA Haeckel, 1896

Order SCLERACTINIA Bourne, 1900

Family ACROPORIDAE Verrill, 1902 
Diagnosis. Massive or ramose colonies formed by extracalicular budding; hermatypic; corallites small, synapticulothecate, pseudocostate, slightly differentiated from coenosteum. Septa nonexsert, in two cycles, formed by simple spiniform trabeculae projecting inward and upward from vertical mural trabeculae, commonly fusing to form laminae. Columella absent or trabecular and weak. Dissepiments thin and tabular when developed. Coenosteum extensive, light, reticulate, flaky, generally spinose or striate on surface (Wallace, 1999).

Genus ACROPORA Oken, 1815

Type species. Millepora muricata Linnaeus, 1758 (type by subsequent designation).

Diagnosis. Acroporidae, which are ramose, rarely massive or encrusting, branching with a single axial or leading corallites larger than the numerous radial corallites budded from them; radial corallites variously differentiated in outline; united by light reticulate, spinose, costate or pseudocostate coenosteum; columella and dissepiments absent (Wallace, 1999).

Occurrence and distribution. Paleocene recent, worldwide in tropical and sub-tropical regions. Oldest record in the Central Indo-Pacific, Oligocene, Sabah, Malaysia (McMonagle, 2012) and Sulawesi, Indonesia (Wilson and Rosen, 1998).

\section{Acropora sp. A}

Figure 2.1-2

Material and occurrence. Butong Limestone Formation: QMF58030, QMF58031, QMF58032, QMF58033, QMF58034, QMF58035, QMF58036; Calagasan Formation: QMF58037. Chattian. Argao, Cebu, Malaysia (BLF1, BLF2, and CF1).

Description. Colonies branching, with branches $7.95-20.51 \mathrm{~mm}$ in diameter. Branches mostly circular in cross-section, thicker branches elliptical. Axial and radial corallites present. Corallites discrete (monocentric). Coenosteum reticulate, uneven amount (spacing between corallites 1.22 $3.10 \mathrm{~mm}$ ). Radial corallites round in outline and small, $0.93-1.28 \mathrm{~mm}$, with two septal cycles.

Remarks. Studied material is comprised of fragments of coral branches, but the tips of the branches are not preserved. However, axial corallites occur on cross-sections of branches as they dominate the diameter of branches. Axial corallites that dominate the diameter of the branches as well as reticulate coenosteum with laterally flattened irregular spinules are characteristic of species within the Acropora humilis group (Wallace, 1999). Although recent review of Acroporiids from the
Central Indo-Pacific described three Acropora species (A. monticulosa, A. samoensis, A. laurae) within the Acropora humilis group (Santodomingo et al., 2015a), poor preservation of the present material precludes such degree of identification.

\section{Acropora sp. B \\ Figure 2.3}

Material and occurrence. Butong Limestone Formation: QMF58038, QMF58039, QMF58040, QMF58041, QMF58200; Calagasan Formation: QMF58042, QMF58043, QMF58044, QMF58201, QMF58202. Chattian. Argao, Cebu, Philippines (BLF2, BLF4, CF1, CF4, and CF6).

Description. Colonies branching, with branches $3.20-10.42 \mathrm{~mm}$ in diameter. Branches mostly circular in cross-section. Corallites discrete (monocentric). Coenosteum costate, uneven amount (spacing between corallites $1.51-2.68 \mathrm{~mm}$ ). Axial corallites $0.86-1.37 \mathrm{~mm}$ in diameter. Radial corallites tubular, round in outline and small, $1.02-1.88$ $\mathrm{mm}$, with two septal cycles.

Remarks. Studied material is comprised of fragments of coral branches but the tips of the branches are not preserved. However, axial corallites occur on cross-sections of branches. Axial and radial corallites contribute equally to the branch structure. Radial corallites are tubular and irregularly distributed. Coenosteum composed of aligned simple spinules becomes costate in most studied branch fragments. All these characters are characteristic of species within the Acropora horrida group (Wallace, 1999). Recent review of Acroporiids from the Central Indo-Pacific described eight Acropora species within the Acropora horrida group (Santodomingo et al., 2015a): A. horrida, $A$. vaughani, A. tortuosa, A. halmaherae, A. kirstyae, $A$. emanuelae, $A$. derawanensis and $A$. filiformis. However, due to the poor preservation, studied material could not be further identified.

Genus ALVEOPORA de Blainville, 1830

Type species. Madrepora daedalea Forskål, 1775 (type by subsequent designation).

Diagnosis. Acroporidae, which are ramose or massive, often with irregular shapes. Skeletal structure very light, consisting of interconnecting rods and spines. Corallites polygonal with latticelike walls. Septa spiniform. Columella absent (Veron and Pichon, 1976).

Occurrence and distribution. Paleocene recent, worldwide in tropical and sub-tropical regions. Oldest record in the Central Indo-Pacific, Eocene, Marshall Islands (Wells, 1964). 


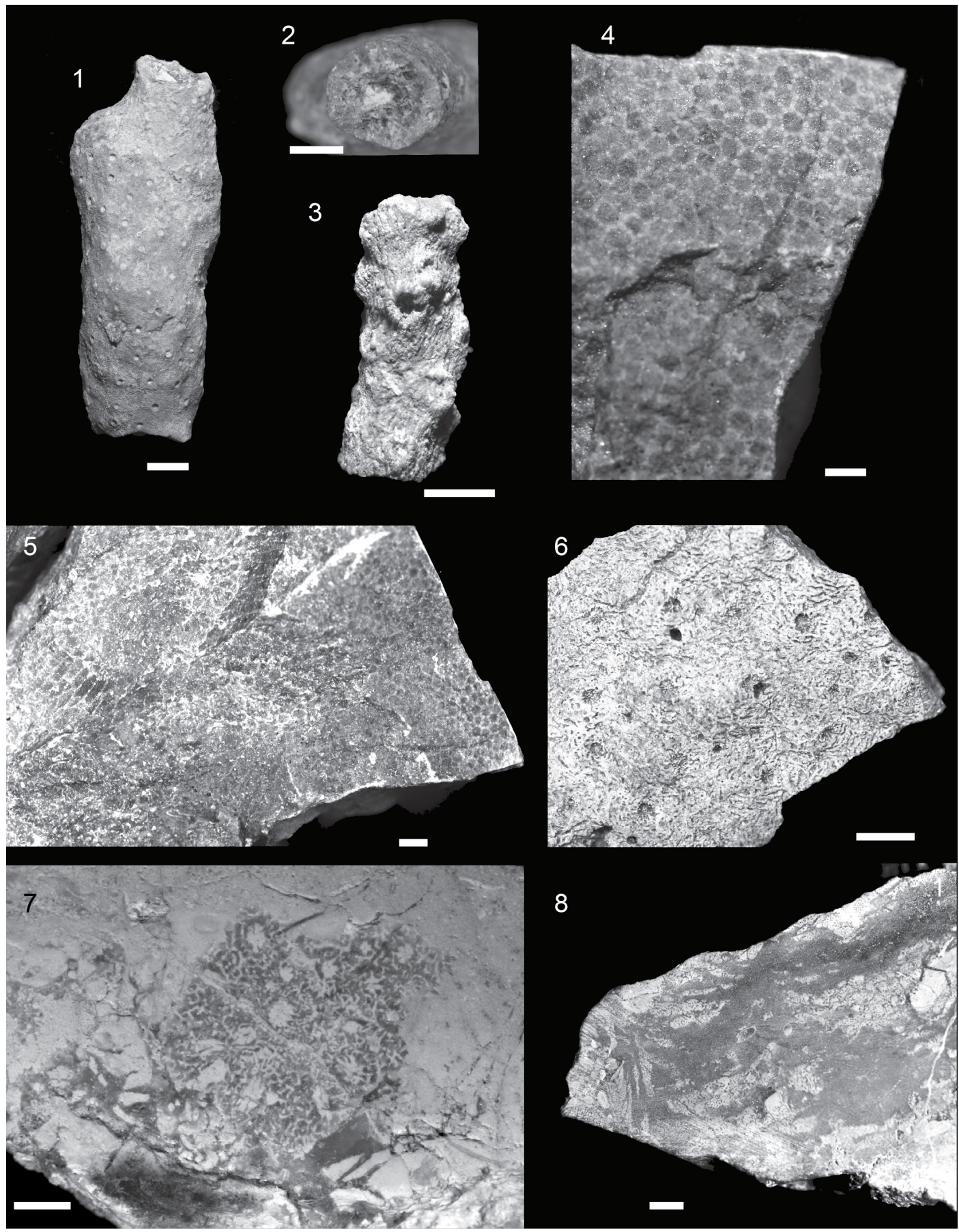

FIGURE 2. 1) Acropora sp. A, QMF58030, Butong Formation (late Oligocene - late Chattian), Cebu. Branch fragment with reticulate coenosteum and uneven spacing between corallites. 2) Acropora sp. A, QMF58030, Butong Formation (late Oligocene - late Chattian), Cebu. Cross-section through the branch outlining the axial corallite. 3) Acropora sp. B, QMF58038, Butong Formation (late Oligocene - late Chattian), Cebu. Branch fragment with costate coenosteum. 4) Alveopora cf. fenestrata, QMF58045, Melinau Limestone (early Miocene - Aquitanian), Sarawak. Irregularly shaped corallites with lattice-like walls. 5) Alveopora cf. fenestrata, QMF58045, Melinau Limestone (early Miocene Aquitanian), Sarawak. Massive colony preserved in dense limestone matrix. 6) Astreopora cf. expansa, QMF58047, Butong Formation (late Oligocene - late Chattian), Cebu. Bifacial plate with uneven spacing between immersed corallites. 7) Astreopora cf. digitata, QMF58053, Subis Limestone (early Miocene - Aquitanian), Sarawak. Cross-section through the specimen. Discrete (monocentric) corallites surrounded by reticulate coenosteum. 8) Astreopora cf. digitata, QMF58048, Subis Limestone (early Miocene - Aquitanian), Sarawak. Cross-section through the specimen. Massive colony preserved in dense limestone matrix. Scale bars equal $2 \mathrm{~mm}(7) ; 3 \mathrm{~mm}(4) ; 5 \mathrm{~mm}(1,2,3,5,6,8)$. 
Alveopora cf. fenestrata (Lamarck, 1816)

Figure 2.4-5

1816 Pocillopora fenestrata Lamarck, p. 275.

1864 Alveopora retusa Verrill, p. 43.

1982 Alveopora fenestrata (Lamarck); Veron and Pichon, p.121, figs. 224-249.

2000 Alveopora fenestrata (Lamarck); Veron, p. 386 (vol. 3).

Type locality. Southern Ocean (Lamarck, 1816).

Material and occurrence. Melinau Limestone: QMF58045, QMF58046. Aquitanian. Gunung Mulu, Sarawak, Malaysia (ML).

Description. Colonies massive. Corallites discrete (monocentric). Coenosteum absent to limited. Corallites irregular in outline, $1.21-1.44 \mathrm{~mm}$ in diameter with lattice-like walls.

Remarks. Studied material is preserved in massive limestone. Despite cutting and polishing the cut surface, the poor preservation of material does not allow any identification of septal structure. However, the light skeletal structure consisting of interconnecting rods and spines, characteristic of Alveopora, is visible in the corallite walls and can be recognized where the white skeletal elements (rods and spines) are interrupted by gaps of dark limestone matrix. These lattice-like walls, combined with the size and arrangement of corallites, correspond with genus Alveopora. Several Alveopora species with (sub)massive colony shape have been reported in the Cenozoic fossil record of the Central Indo-Pacific (A. fenestrate, $A$. jessicae and $A$. oliveri). The studied material matches $A$. fenestrata in corallite size and arrangement. Lattice walls and hexagonal arrangement of corallites resemble modern material described by Veron and Pichon, 1982, especially the colonies from Marion Reef with short needle-like septa. Alveopora fenestrata is known in the fossil record only in the early Miocene of Indonesia (Jordan and Abdullah, 1992). This species is uncommon yet widely distributed throughout the modern Central Indo-Pacific (Veron, 2000).

Genus ASTREOPORA de Blainville, 1830

Type species. Astraea myriophthalma Lamarck, 1816 (type by subsequent designation).

Diagnosis. Acroporidae, which are massive, subramose, plate-like or encrusting. Axial corallite rarely present. Columella absent, but pseudo-columella, formed by trabecular extensions of the septa, may be present. Coenosteum reticular, formed by outwardly inclined trabeculae, with spinose surface. Dissepiments tabular (Wallace et al., 2011).
Occurrence and distribution. Cretaceous recent, worldwide in tropical and sub-tropical regions. Oldest record in the Central Indo-Pacific, Eocene, Marshall Islands (Wells, 1964).

Astreopora cf. expansa Brüggemann, 1877

Figure 2.6

1877 Astraeopora expansa Brüggemann, p. 416.

2000 Astreopora expansa (Brüggemann); Veron, p. 434 (vol. 1).

Type locality. Unrecorded (Brüggemann, 1877).

Material and occurrence. Butong Limestone Formation: QMF58047. Chattian. Argao, Cebu, Philippines (BLF2).

Description. Colony plate-like, bifacial, $7.15-7.73$ $\mathrm{mm}$ in thickness. Corallites discrete (monocentric). Coenosteum reticulate, uneven amount (spacing between corallites $2.72-5.93 \mathrm{~mm}$ ). Corallites round in outline and immersed, $1.31-1.95 \mathrm{~mm}$ in diameter.

Remarks. Studied material is characterized by bifacial, plate-like colonies, a feature known only from Astreopora expansa. Astreopora cf. expansal cf. rutteni complex has been reported from the Oligocene of Sabah, Malaysia (McMonagle, 2012). Astreopora rutteni although similar in colony shape, corallite size and appearance does not have bifacial plates (Gerth, 1923), thus, studied material is assigned to $A$. expansa. Species description by Brüggemann, 1877, does not mention the colony bifaciality, and because it is not accompanied by a figure this feature cannot be confirmed. However, Veron, 2000, acknowledges Brüggemann's $A$. expansa (from an unknown locality) and identifies bifacial colonies from a variety of Indo-Pacific localities as $A$. expansa. This species is uncommon yet widely distributed through the modern Central Indo-Pacific (Veron, 2000).

Astreopora cf. digitata (Gerth, 1925)

Figure 2.7-8

1925 Polysolenia digitata Gerth, p. 23, 36, 70, pl. 5, figs. 2-2a.

1931 Polysolenia digitata Gerth, p. 145.

2007 Astreopora digitata (Gerth); Leloux and Renema, p. 23, pl. 27, figs. 1-4.

Type locality and horizon. Nias Formation, Idanogawo-Sagaeaju, Nias, Indonesia (Gerth, 1925).

Material and occurrence. Subis Limestone: QMF58048, QMF58049, QMF58050, QMF58051, QMF58052, QMF58053, QMF58054, QMF58055, QMF58056. Aquitanian. Niah, Sarawak, Malaysia (SL1 and SL2).

Description. Corallites discrete (monocentric). Coenosteum reticulate, uneven amount (spacing 
between corallites $0.43-1.02 \mathrm{~mm}$ ). Corallites round in outline, $1.11-1.71 \mathrm{~mm}$ in diameter.

Remarks. Colony shape is difficult to define as the corals are embedded in dense limestone matrix. The material is generally poorly preserved, and corallites are visible only on cut surfaces. In its corallite size and coenosteum texture, the examined material resembles fossil species Astreopora hochstetteri and $A$. digitata known from the Central Indo-Pacific fossil record (Gerth, 1925, 1931; Leloux and Renema, 2007). However, the spacing between corallites in $A$. hochstetteri is wider than in the studied material (Gerth, 1925, 1931; Leloux and Renema, 2007), thus, the material is assigned to $A$. digitata. Astreopora digitata has branching to columnar colony shape and is known from Late Miocene of Indonesia (Gerth, 1925).

\section{Family AGARICIIDAE Gray, 1847}

Diagnosis. Solitary (ahermatypic and azooxanthellate) or colonial (hermatypic and zooxanthellate), attached. Colony shape branching, massive, columnar, encrusting or foliose, all formed mainly by intracalicular circumoral budding. Wall septothecate or synapticulothecate, the latter usually becoming solid or absent. Septa rarely porous, formed by a continuous middle rapid accretion zone flanked by perpendicular to slightly oblique bundles of fibers (thickening deposits). Septal margins usually beaded. Septa from colonial representatives directly confluent between centers, united by compound synapticulae. Septal faces with scale-like microtexture and bear rows of granules or menianes, both composed of RAD (zone of Rapid Accretion Deposits). Endothecal dissepiments mostly absent. Columella trabecular or absent (Kitahara et al., 2012).

Genus GARDINEROSERIS Scheer and Pillai, 1974

Type species. Agaracia ponderosa Gardiner, 1905 (type by subsequent designation).

Diagnosis. Agariciidae, which are massive to encrusting, sometimes with laminar margins. Corallites with poorly defined walls but separated by acute ridges, placing each corallite or group of corallites at the bottom of a neatly rounded excavation. Columellae present. Costosepta fine and evenly spaced (Veron, 1986).

Occurrence and distribution. Oligocene - recent, (sub)tropical Caribbean and Indo-Pacific. Oldest record in the Central Indo-Pacific, Oligocene, Sabah, Malaysia (McMonagle, 2012).
Gardineroseris cf. planulata (Dana, 1846)

Figure 3.1

1846 Agaricia planulata Dana, p. 338.

1901 Asteroseris planulata (Dana); Verrill, p. 156, pl. 27, fig. 8.

1905 Agaricia ponderosa Gardiner, p. 937, pl. 39, figs. 5-6.

1936 Pavona (Polyastra) planulata (Dana); Wells, p. 551.

1974 Gardineroseris ponderosa (Gardiner); Scheer and Pillai, p.32, pl. 15, figs. 1-2.

1980 Gardineroseris planulata (Dana); Veron and Pichon, p. 68-72, figs. 121-125. 2000 Gardineroseris planulata (Dana); Veron, p. 222 (vol. 2).

Type locality. Unrecorded (Dana, 1846).

Material and occurrence. Butong Limestone Formation: QMF58057. Chattian. Argao, Cebu, Philippines (BLF2).

Description. Colony encrusting. Corallites discrete. Coenosteum absent. Corallites/short valleys irregular in outline and relief, relief $0.92-4.68 \mathrm{~mm}$. Width of corallites/valleys $4.41-10.53 \mathrm{~mm}$. Costosepta fine and evenly spaced, $12-15$ septa per 5 $\mathrm{mm}$, and covered with small granules. Some septa reach the corallite center, some only reach halfway. Remarks. Gardineroseris planulata is the only described species of this genus. In the fossil record, this species is known from Oligocene of Sabah, Malaysia (McMonagle, 2012). The studied material together with the Gardineroseris records from Sabah are the oldest known fossil record from the Indo-Pacific prior to the mid-Miocene of Indonesia (Santodomingo et al., 2016). The species is first described by Dana, 1846, and was characterized by polygonal corallites and very fine costosepta. Coral materials described by Verrill, 1901, Gardiner, 190, and Wells, 1936 all have smaller average corallite size $(4-5 \mathrm{~mm})$ than studied Philippine material. However, overall corallite appearance resembles the Philippine material. Scheer and Pillai, 1974, erected a new genus and conclude that previously differentiated species ponderosa and planulata are the same species. The same conclusion was reached also by Veron and Pichon, 1980. The studied material resembles in corallite size and appearance the figures of Gardineroseris planulata provided both by Veron and Pichon, 1980, and Veron, 2000. This species is uncommon yet widely distributed through the modern Central Indo-Pacific (Veron, 2000). 


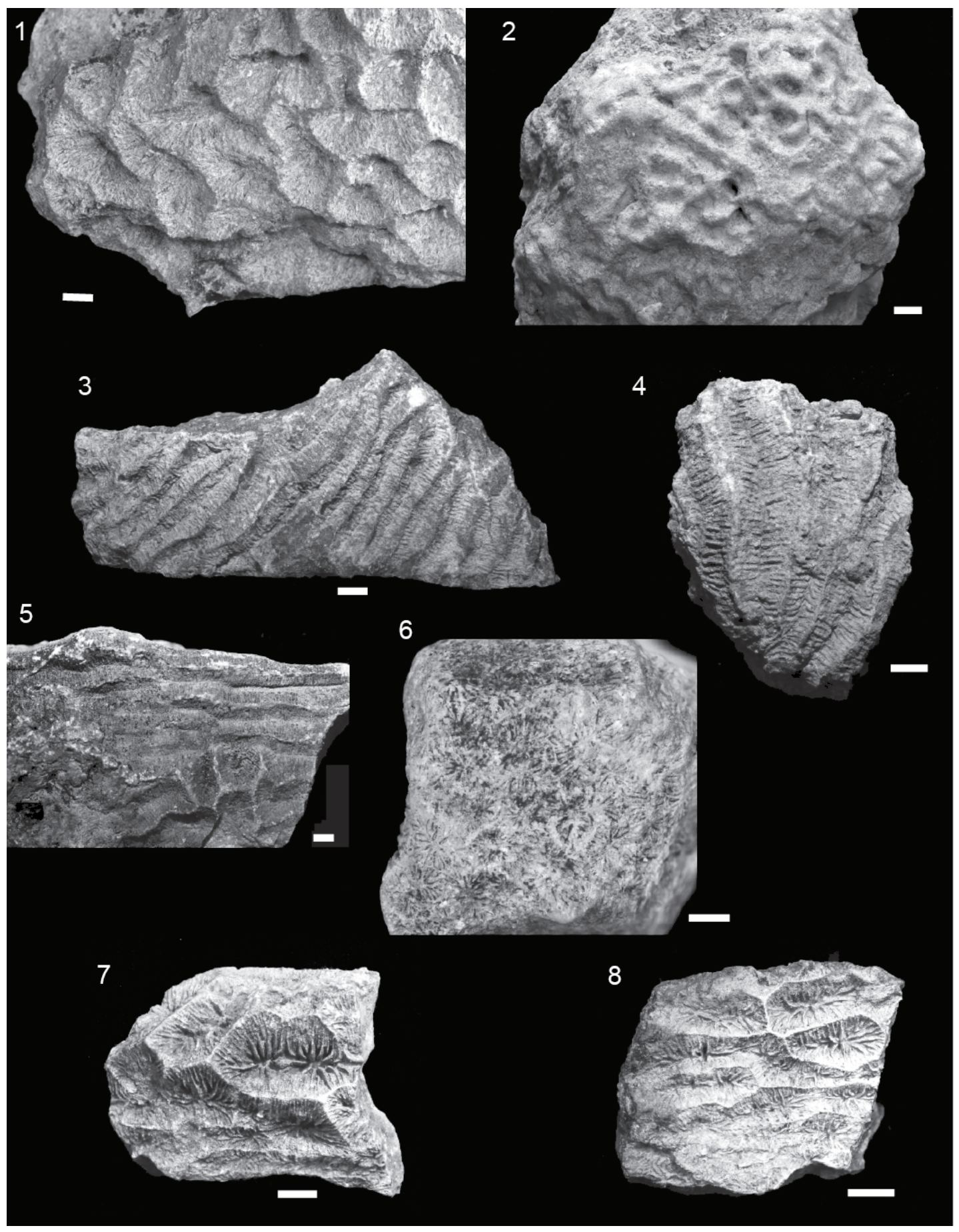

FIGURE 3. 1) Gardineroseris cf. planulata, QMF58057, Butong Formation (late Oligocene - late Chattian), Cebu. Encrusting colony with corallites/short valleys irregular in shape and relief. 2) Leptoseris sp. A, QMF58075, Butong Formation (late Oligocene - late Chattian), Cebu. Encrusting colony with dense and irregular folds on the surface. 35) Pachyseris spp., laminar and unifacial colonies with mostly parallel valleys. Examples here show variation in width and length of valleys: QMF58098, Butong Formation (late Oligocene - late Chattian), Cebu (3); QMF58111, Butong Formation (late Oligocene - late Chattian), Cebu (4); QMF58113, Butong Formation (late Oligocene - late Chattian), Cebu. 6) Pavona cf. clavus, QMF58116, Calagasan Formation (late Oligocene - middle Chattian), Cebu. Columnar colony with sub-circular corallites interconnected by prominent costosepta. 7-8) Pavona cf. venosa, encrusting colonies with discrete corallites (one to three centers). Examples here show variation in width and outline of corallites: QMF58118, Butong Formation (late Oligocene - late Chattian), Cebu (7); QMF58121, Butong Formation (late Oligocene - late Chattian), Cebu (8). Scale bars equal $5 \mathrm{~mm}$. 


\section{Genus LEPTOSERIS Milne Edwards and Haime, 1849}

Type species. Leptoseris fragilis Milne Edwards and Haime, 1849 (type by monotypy).

Diagnosis. Agariciidae, which are laminar (usually unifacial) or encrusting with often a distinctive central corallite. Corallites small shallow depressions with poorly defined walls and a central columella, usually separated by ridges and interconnected by fine costosepta (Veron, 1986).

Occurrence and distribution. Oligocene - recent, worldwide in tropical and sub-tropical regions. Oldest record in the Central Indo-Pacific, Oligocene, Sabah, Malaysia (McMonagle, 2012).

\section{Leptoseris sp. A}

Figure 3.2

Material and occurrence. Butong Limestone Formation: QMF58075. Chattian. Argao, Cebu, Philippines (BLF4).

Description. Colony encrusting with dense and irregular folds on the surface. Corallites situated in between folds forming short valleys (two to five centers), $2.51-5.40 \mathrm{~mm}$ in width. Coenosteum limited. Costosepta are fine and even.

Remarks. Leptoseris sp. A is characterized by short rounded valley walls that are characteristically folded, features currently known only from $L$. mycetoseroides, an extant species. Leptoseris mycetoseroides is widely distributed through the modern Central Indo-Pacific (Veron, 2000) and known from the late Pleistocene fossil record of Japan (Nakamori, 1986; Sasaki et al., 2004). Due to poor preservation of the studied material, characters needed for identifying it as $L$. mycetoseroides, such as number and thickness of septa, the position and number of corallites and appearance of columella (Wells, 1954), are not available. The only other Leptoseris species known from the Oligocene of the Central Indo-Pacific is $L$. aff. glabra/ scabra. This species lacks folded rounded walls and has much wider valleys (up to $11 \mathrm{~mm}$ ) (McMonagle, 2012). Thus, the studied material is also not assigned to this species.

\section{Genus PACHYSERIS Milne Edwards and Haime} 1849

Type species. Agaricia rugosa Lamarck, 1801 (type by original designation).

Diagnosis. Agariciidae, which are laminar and unifacial or branching to bifacial, with a series of concentric ridges parallel to the corallum edge. Corallite centers mostly indistinguishable, except when secondary calices present on sides of carinae. Costosepta fine, even and tightly compacted.
Columellae are wall-like with lobed upper margins or absent (Veron, 1986; Terraneo et al., 2014).

Occurrence and distribution. Eocene - recent, Indo-Pacific and Tethys. Oldest record in the Central Indo-Pacific, Oligocene, Sabah, Malaysia (McMonagle, 2012).

\section{Pachyseris spp. \\ Figure 3.3-5}

Material and occurrence. Butong Limestone Formation: QMF58100, QMF58099, QMF58058, QMF58059, QMF58101, QMF58102, QMF58060, QMF58061, QMF58062, QMF58063, QMF58064, QMF58065, QMF58076, QMF58077, QMF58103, QMF58104, QMF58078, QMF58079, QMF58105, QMF58080, QMF58081, QMF58082, QMF58066, QMF58106, QMF58083, QMF58067, QMF58107, QMF58084, QMF58108, QMF58085, QMF58086, QMF58087, QMF58088, QMF58068, QMF58069, QMF58070, QMF58089, QMF58109, QMF58090, QMF58091, QMF58110, QMF58111, QMF58092, QMF58093, QMF58112, QMF58071, QMF58072, QMF58094, QMF58095, QMF58096, QMF58097, QMF58098, QMF58113, QMF58114, QMF58073, QMF58115, QMF58136, QMF58137; Calagasan Formation: QMF58074. Chattian. Argao, Cebu, Philippines (BLF2, BLF4, and CF2).

Remarks. Studied material is characterized by laminar and unifacial colonies that have series of parallel ridges, and fine, evenly spaced costosepta (eight to 10 per $5 \mathrm{~mm}$ ) perpendicular to columella. The colonies show variation in width $(3.56-9.92$ $\mathrm{mm}$ ) and length $(4->40 \mathrm{~mm})$ of valleys, which indicates several species. Most of the studied material probably belongs to Pachyseris curvata, a common species throughout the Neogene of the Central Indo-Pacific (Umbgrove, 1945, 1946b; Bromfield, 2013). However, valley widths of studied material exceed those described for $P$. curvata (3$5 \mathrm{~mm}$; Umbgrove, 1946b). Only two fossil species have valley widths exceeding $5 \mathrm{~mm}$ : $P$. aff. foliosa/ involuta and $P$. speciosa, both reported from Oligocene of Sabah (McMonagle, 2012). Pachyseris aff. foliosa/involute has very specific valley folds that are not observed in the studied material. Samples with larger corallites might belong to $P$. speciosa. However, due to the overlap in size of valley widths in $P$. cuvata and $P$. speciosa and poor preservation of studied material, it is not possible to distinguish between these two species. Moreover, characters needed for separation of species require detailed description of columella structure and septal ornamentation, which are not preserved (well) in studied material. 


\section{Genus PAVONA Lamarck 1801}

Type species. Madrepora cristata Ellis and Solander, 1786 (type by subsequent designation).

Diagnosis. Agariciidae, which are massive to plate-like (usually bifacial), some are columnar. Corallites small shallow depressions, with poorly defined walls, usually with a central columella, sometimes separated by ridges. Corallites interconnected by prominent costosepta (Veron, 1986).

Occurrence and distribution. Paleocene recent, worldwide in tropical and sub-tropical regions. Oldest record in the Central Indo-Pacific, Eocene, Marshall Islands (Wells, 1964).

Pavona cf. clavus (Dana, 1846)

Figure 3.6

1846 Pavonia clavus Dana, p. 332, pl. 24, figs. 4a-4b.

1924 Siderastraea clava (Dana). Umbgrove, p. 12, pl. 2, fig. 8.

1879 Siderastrea liliacea Klunzinger, p. 7, pl. 9, fig. 6, pl. 10, figs. 16a-16b.

1904 Siderastrea liliacea Klunzinger; Gardiner, p. 935.

1922 Pavona clavus Dana; Van der Horst, p. 420, pl. 41, fig. 7.

1946a Pavona clavus Dana; Umbgrove, p. 538.

1954 Pavona clavus Dana; Wells, p. 441, pl. 152, figs. 1-2.

1979 Pavona clavus Dana; Veron and Pichon, p. 21, figs. 35-40.

2000 Pavona clavus Dana; Veron, p. 198 (vol. 2).

Type locality. Fiji (Dana, 1846).

Material and occurrence. Calagasan Formation: QMF58116; Subis Limestone: QMF58117, QMF58232. Chattian to Aquitanian. Argao, Cebu, Philippines; Niah, Sarawak, Malaysia (SL1 and CF6).

Description. Colonies columnar. Corallites discrete (one to three centers), with poorly defined walls. Corallites $4.25-6.08 \mathrm{~mm}$ in width, sub-circular in outline and interconnected by prominent costosepta.

Remarks. Colony shape and corallite arrangement, size and appearance of studied material resembles Pavona clavus (Dana, 1846; Van der Horst, 1922; Umbgrove, 1924, 1946a; Wells, 1954; Veron and Pichon, 1980). Prior to description of this material $P$. clavus has been known from the Central Indo-Pacific fossil record since the late Miocene (Umbgrove, 1945), making the studied material the oldest fossil record of this species. This species is widely distributed throughout the modern Indo-Pacific (Veron and Pichon, 1980; Veron, 2000). Colony shape of sample QMF58117 is not clear due to its preservation in a dense limestone matrix. However, corallite arrangement, appearance and size match those of sample QMF58116.

\section{Pavona cf. venosa (Ehrenberg, 1834)}

\section{Figure 3.7-8}

1898 Pavonia calcifera Gardiner, p. 532, pl. 44, fig. 4.

1936 Pavona (Polyastra) obtusata (Quelch); Wells, p. 551, pl. 9, figs. 1-3.

1936 Pavona (Polyastra) venosa (Ehrenberg); Wells, p. 551, pl. 9, figs. 4-5.

1979 Pavona (Polyastra) venosa (Ehrenberg); Veron and Pichon, p. 30, figs. 55-57.

2000 Pavona (Polyastra) venosa (Ehrenberg); Veron, p. 190 (vol. 2).

2013 Pavona (Polyastra) venosa (Ehrenberg); Bromfield, p. 11, pl.4, figs. 4-5.

Type locality. Red Sea (Ehrenberg, 1834).

Material and Occurrence. Butong Limestone Formation: QMF58118, QMF58120, QMF58121, QMF58122, QMF58123, QMF58124, QMF58125. Chattian. Argao, Cebu, Philippines (BLF2 and BLF4).

Description. Colonies encrusting. Corallites discrete (one to three centers), with poorly defined walls and central columella. Corallites shallow depressions, separated by ridges, $1.99-10.41$ $\mathrm{mm}$ in width. Corallites interconnected by prominent costosepta.

Remarks. Studied material resembles extant Pavona venosa in colony shape, corallite arrangement and appearance (Bromfield, 2013), but some of the studied material has corallites up to two (Gardiner, 1898; Wells, 1936) to five (Veron and Pichon, 1979; Veron, 2000) times larger than reported by other authors. Wells, 1936 describes two similar species, $P$. venosa and $P$. obtusata. These two species were recognised as variants and synonomised by Veron and Pichon, 1979 due to the variation in the width and length of colony ridges. This variation is observed in the studied material and is common in extant $P$. venosa (Veron and Pichon, 1980). Pavona venosa is known from the Central Indo-Pacific fossil record since the early Miocene (Bromfield, 2013), making the studied material the oldest fossil record of this species. This species is uncommon yet widely distributed throughout the modern Indo-Pacific (Veron, 2000).

\section{Family CARYOPHYLLIIDAE Dana, 1846}

Diagnosis. Solitary or colonial. Colony formation by extracalicular budding forming phaceloid or dendroid colonies. Septa laminar with smooth or nearly smooth margins, composed of one fan system of 
small, simple trabeculae. Costae commonly covered by stereome or ephitheca. Septa exsert. Columella formed by curled trabeculae, solid, spongy or absent. Pali or paliform lobes common. Endothecal dissepiments present in some groups (Wallace et al., 2009).

Genus TROCHOCYATHUS Milne Edwards and Haime, 1848

Type species. Turbinolia mitrata Goldfuss, 1827 (type by subsequent designation).

Diagnosis. Caryophylliidae, which are solitary, attached or free-living. Corallum conical in shape. Theca granular, the granules usually occurring on longitudinally oriented costae. Columella papillose. Pali or paliform lobes present, base monocyclic. Pali before septa of all but last cycle, palar crowns discrete (Cairns and Kitahara, 2012).

Occurrence and distribution. Jurassic - recent, worldwide in tropical and sub-tropical regions. Oldest record in the Central Indo-Pacific, Eocene, Indonesia (Wilson and Rosen, 1998).

Trochocyathus cf. schmidti Gerth, 1923

Figure 4.1-2

1923 Trochocyathus schmidti Gerth,p. 54-55, pl. 1, fig. 11-13.

1925 Trochocyathus schmidti (Gerth); Gerth, p. 52.

1931 Trochocyathus schmidti (Gerth); Gerth, p. 130.

Type locality and horizon. Tanah Belang, Borneo, Indonesia (Gerth, 1923).

Material and occurrence. Butong Limestone Formation: QMF58126; Calagasan Formation: QMF58127. Chattian. Argao, Cebu, Philippines (CF7).

Description. Solitary, attached or free-living. Corallum conical in shape, oval in outline, $11.29-11.5$ $\mathrm{mm}$ in diameter, $10.8-13.74 \mathrm{~mm}$ in height. Theca granular, the granules usually occurring on longitudinally oriented costae. Columella papillose.

Remarks. Studied material comprises two individuals of different preservation: sample QMF58126 is complete but the interior of the corallite is filled with lithified sediment, and corallum of QMF58127 is only partly preserved. Despite palar structure not being preserved in both samples preventing confident species identification, the corallum shape, size, granular theca, longitudinal costae and papillose columella allow identification of the studied material as genus Trochocyathus. Only two Trochocyathus species are known from the Central Indo-Pacific: discoid $T$. nummiformis from late Eocene of Indonesia (Wilson and Rosen, 1998) and conical T. schmidti from late Miocene of Indonesia (Gerth, 1923). Conical shape of $T$. schmidti corallum corresponds to the corallum shape of the studied material, thus, it is assigned to T. schmidti. Trochocyathus schmidti has been reported several times from Malaysian Borneo (Gerth, 1923, 1925, 1931).

\section{Family EUPHYLLIIDAE Alloiteau, 1952}

Diagnosis. Colonies are phaceloid, meandroid or flabello-meandroid, with large, solid and widely spaced costosepta which have little or no ornamentation. Corallite walls have a similar structure. All species are zooxanthellate (Turak et al., 2012).

Genus GALAXEA Milne Edwards, 1857

Type species. Madrepora fascicularis Linnaeus, 1767 (type by subsequent designation).

Diagnosis. Euphylliidae, which are massive, columnar, encrusting or irregular. Corallites cylindrical, thin-walled and separated by a blistery coenosteum. Columellae weak or absent. Septa very exsert (Veron, 1986).

Occurrence and distribution. Oligocene - recent, worldwide (mostly Indo-Pacific). Oldest record in the Central Indo-Pacific, Eocene, Marshall Islands (Wells, 1964).

Galaxea sp. A

Figure 4.3-4

Material and occurrence. Calagasan Formation: QMF58138, QMF58141, QMF58142; Subis Limestone: QMF58139, QMF58140. Chattian to Aquitanian. Argao, Cebu, Philippines (CF5, CF6 and SL1).

Description. Colonies encrusting to massive. Corallites monomorphic and discrete (monocentric). Coenosteum moderate/uneven amount $(<$ corallite diameter), Corallites cylindrical and $4.28-6.80$ $\mathrm{mm}$ in diameter. Septa in three cycles (24- 36 septa). Columellae are weak.

Remarks. Studied material varies in preservation quality; colony shape is difficult to discern in some samples (mostly those preserved in dense limestone matrix, e.g., QMF58139) while others even have the colony relief preserved (e.g., QMF58141). Despite the differences in preservation, all samples assigned to Galaxea sp. A due to resemblance with this genus in colony growth form, corallite size and appearance, as well as septal arrangement. Although none of the samples have preserved strongly exsert septa, characteristic of genus Galaxea, all the other characters mentioned above correspond with the genus diagnosis. However, due to the preservation quality identification beyond genus level is not possible. Samples QMF58141 and QMF58142 are preserved on the 


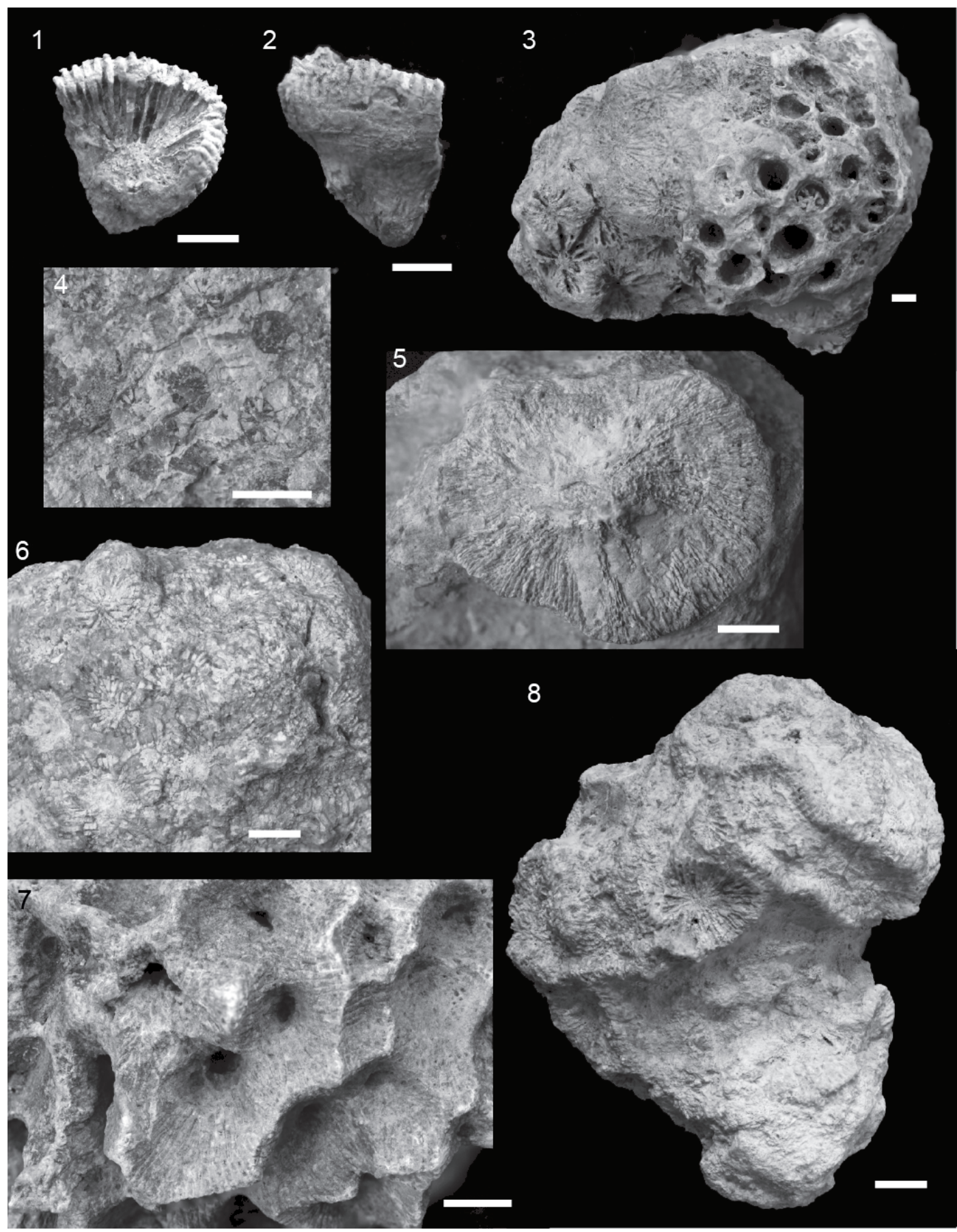

FIGURE 4. 1) Trochocyathus cf. schmidti, QMF58127, Calagasan Formation (late Oligocene - middle Chattian), Cebu. Solitary coral, oval in outline with papillose columella. 2) Trochocyathus cf. schmidti, QMF58127, Calagasan Formation (late Oligocene - middle Chattian), Cebu. Lateral view of coral showing its conical shape. 3) Galaxea sp. A, QMF58141, Calagasan Formation (late Oligocene - middle Chattian), Cebu. Encrusting colony with cylindrical corallites. 4) Galaxea sp. A, QMF58139, Subis Limestone (early Miocene - Aquitanian), Sarawak. Colony preserved in dense limestone. 5) Fungia spp., QMF58144, Calagasan Formation (late Oligocene - middle Chattian), Cebu. Solitary coral with only aboral surface preserved. 6) Acanthastrea cf. echinata, QMF58151, Calagasan Formation (late Oligocene - middle Chattian), Cebu. Massive colony with corallites rounded to elliptical in outline. 7) Acanthastrea sp. A, QMF58148, Calagasan Formation (late Oligocene - middle Chattian), Cebu. Massive colony with irregularly shaped corallites. 8) Lobophyllia cf. hemprichii, QMF58153, Calagasan Formation (late Oligocene - middle Chattian), Cebu. Phaceloid to flabello-meandroid colony with both monocentric corallite and short valley preserved. Scale bars equal 5 $\mathrm{mm}(1,2,3,4) ; 10 \mathrm{~mm}(5,6,7,8)$. 
same limestone block as Favites sp. cf. chinensis colony (QMF58210 and QMF58211).

Family FUNGIIDAE Dana, 1846

Diagnosis. Solitary or colonial, attached or free, mono - or polystomatous. Corallum flat or convex, circular to oval in outline, with solid or perforated wall. Septa numerous, perforate (higher orders) or solid, with simple or compound marginal dentations. Adjacent septa connected by compound synapticulae. Costae continuous or broken, ornamented (Hoeksema, 1989).

\section{Genus FUNGIA Lamarck, 1801}

Type species. Madrepora fungites Linnaeus, 1758 (type by subsequent designation).

Diagnosis. Fungiidae, which are solitary and freeliving, monostomatous. Corallum flat or convex, circular to oval in outline, with solid or perforated wall. Septa and costae numerous, varying from equal to unequal, with fine to coarse ornamentations (Hoeksema, 1989).

Occurrence and distribution. Eocene - recent, Indo-Pacific and Tethyan. Oldest record in the Central Indo-Pacific, Oligocene, Sabah, Malaysia (McMonagle, 2012).

\section{Fungia spp.}

Figure 4.5

Material and occurrence. Calagasan Formation: QMF58143, QMF58144, QMF58145; Melinau Limestone: QMF58146. Chattian to Aquitanian. Argao, Cebu, Philippines (CF2 and CF7); Gunung Mulu, Sarawak, Malaysia (ML).

Remarks. Studied material is characterised by flat, oval corallum (30.17 - $46.33 \mathrm{~mm}$ in diameter), welldeveloped and numerous septa and costae with rounded teeth. The preservation quality of studied material varies greatly: in samples QMF58144 and QMF58145 only the aboral surface is preserved and the numerous, ornamented costae are visible; in sample QMF58146 septal arrangement and synapticulae connections between the septa are preserved. Species of the genus Fungia are separated based on septal characters such as thickness and dentition, as these are not preserved in studied material identification beyond genus level is not possible. Two Fungia spp. individuals (QMF58144 and QMF58145) are preserved on the same limestone block as sample QMF58173. Sample QMF48146 is preserved on the same limestone block as Stylophora spp. (QMF58347).

Family LOBOPHYLLIIDAE Dai and Horng, 2009

Diagnosis. This family was established using molecular phylogenetic analysis (Fukami et al.,
2008). The analysis showed polyphyly of traditional Mussidae. Six genera of traditional Mussidae (Scolymia, Lobophyllia, Cynarina, Symphyllia, Australomussa, Acanthastrea) formed monophyly with Oxypora and Echinophyllia (both traditional Pectiniidae). These eight genera now belong to the newly established family Lobophyllidae. Arrigoni et al. (2014) confirm the monophyly of the Lobophyllidae, but show pervasive non-monophyly at genus level (Echinophyllia, Micromussa, Oxypora, Symphyllia, Acanthastrea and Micromussa).

\section{Genus ACANTHASTREA Milne Edwards and} Haime, 1848

Type species. Acanthastrea spinosa Milne Edwards and Haime, 1848 (type by original designation).

Diagnosis. Lobophylliidae, which are massive, usually flat. Coenosteum absent (fused walls) or limited (double wall). Corallites discrete (one to three centers), either round or polygonal in outline. Costosepta thick near the corallite wall, becoming thin near the columella. Septal margins are dentate (Veron, 1986).

Occurrence and distribution. Oligocene - recent, Indo-Pacific and Tethyan. Oldest record in the Central Indo-Pacific, early Miocene, Indonesia, Fiji and Papua New Guinea (Bromfield, 2013).

\section{Acanthastrea cf. echinata (Dana, 1846)}

Figure 4.6

1846 Astrea echinata Dana, p. 229, pl. 12 figs. 1a$1 \mathrm{~b}$.

1846 Astrea patula Dana, p. 209, pl. 10, fig. 14.

1979 Acanthastrea echinata Dana; Veron and Pichon, p. 253, figs. 423-439.

2000 Acanthastrea echinata Dana; Veron, p. 18 (vol. 3).

2013 Acanthastrea echinata Dana; Bromfield, p. 44.

Type locality. Fiji (Dana, 1846).

Material and occurrence. Calagasan Formation: QMF58147, QMF58150, QMF58151, QMF58503, QMF58504. Chattian - Aquitanian. Argao, Cebu, Philippines (CF6 and CF7); Gunung Mulu, Sarawak, Malaysia (ML).

Description. Colonies massive. Coenosteum limited to moderate. Corallites discrete (one to three centers), rounded to elliptical in outline. Calice width $10.54-15.11 \mathrm{~mm}$. Septa generally in $\geq$ four cycles ( $\geq 48$ septa). Septa spaced nine to 17 septa per $5 \mathrm{~mm}$. Septal margins are dentate. Costosepta are thick near the corallite wall, becoming thin near the columella. Columellae trabecular and spongy, $<1 / 4$ of calice width. 
Remarks. Studied material resembles Lobophylliidae Clade E (Arrigoni et al., 2014) in colony shape, growth form and corallite appearance. Dentition on septal margins (key for species identification), although visible in some samples (e.g., QMF58148), is not sufficiently preserved to confidently allow identification beyond Clade $\mathrm{E}$ level. However, Acanthastrea echinata (Clade E) is known in the Central Indo-Pacific fossil record (middle and late Miocene, Indonesia) (Gerth, 1923; Bromfield, 2013), and the corallite size of the studied material corresponds with this species (Dana, 1846; Veron and Pichon, 1979). Samples QMF58503 and QMF58504 have moderate amount of coenosteum, a feature variable in this species (Veron and Pichon, 1979). Thus, the studied material is the oldest known fossil record of this species. Acanthastrea echinata is usually uncommon yet widely distributed throughout the modern Central Indo-Pacific (Veron, 2000).

\section{Acanthastrea sp. A}

Figure 4.7

Material and occurrence. Calagasan Formation: QMF58148, QMF58149. Chattian. Argao, Cebu, Philippines (CF6 and CF7).

Description. Colonies massive. Coenosteum absent to limited (double wall). Corallites discrete (one to three centers), irregular in outline. Calice width $8.36-22.92 \mathrm{~mm}$. Septa generally in $\geq$ four cycles ( $\geq 48$ septa). Septa spaced eight to 13 septa per $5 \mathrm{~mm}$. Costosepta are equal in relative thickness.

Remarks. In studied material the relief of the corallum appears exaggerated due to diagenetic alterations and corallites appear to be deep, and details such as septal dentition are not preserved. Thus, confident identification beyond genus level is not possible. In comparison to Acanthastrea cf. echinata, Acanthastrea sp. A has limited amount of coenosteum, corallites irregular in outline, and costosepta equal in relative thickness and regular.

Genus LOBOPHYLLIA de Blainville, 1830

Type species. Madrepora corymbosa Forskål, 1775 (type by subsequent designation).

Diagnosis. Lobophylliidae, which are phaceloid to flabello-meandroid. Corallites discrete (one to three centers) to serial, large $(>15 \mathrm{~mm})$. Septa large with regular teeth. Centers with lamellar linkage (Veron, 2000; Wallace et al., 2009).

Occurrence and distribution. Jurassic - recent, Indo-Pacific and Tethyan. Oldest record in the Central Indo-Pacific, early Miocene, Indonesia (Santodomingo et al., 2016).
Lobophyllia cf. hemprichii (Ehrenberg, 1834)

Figure 4.8

1834 Manicina hemprichii Ehrenberg, p. 101.

1886 Mussa brueggemanni Quelch, p. 79, pl.2, fig. 6a-6b.

1979 Lobophyllia hemprichii (Ehrenberg); Veron and Pichon,: 266, figs. 457-471.

2000 Lobophyllia hemprichii (Ehrenberg); Veron, p. 44 (vol. 3).

2013 Lobophyllia hemprichii (Ehrenberg); Bromfield, p. 44 , pl. 29 , figs. 1-2.

Type locality. Red Sea (Ehrenberg, 1834).

Material and occurrence. Calagasan Formation: QMF58152, QMF58153, QMF58154, QMF58155.

Chattian. Argao, Cebu, Philippines (CF6 and CF7).

Description. Colonies phaceloid to fabello-meandroid. Corallites discrete (one to three centers) to serial. Calice width $7.91-19.63 \mathrm{~mm}$. Septa large with exsert teeth. Costae well-developed and beaded. Columellae trabecular, spongy and continuous.

Remarks. Studied material shows variation in preservation of colony shape: sample QMF58153 has monocentric corallites and short valley preserved, sample QMF58152 has a phaceloid 'branch' with two monocentric corallites and sample QMF58155 has two short valleys, the space between which is filled in by limestone matrix. This kind of variation in colony shape is not unusual for Lobophyllia hemprichii (Veron and Pichon, 1979). Moreover, colony shape, growth form and corallite appearance of studied material also matches this species (Ehrenberg, 1834; Quelch, 1886; Veron and Pichon, 1979). Arrigoni et al. (2014) assigned L. hemprichii to Lobophylliidae Clade I (Arrigoni et al., 2014) that includes phaceloid Lobophyllia and the meandroid Symphyllia species. Prior to description of this material $L$. hemprichii has been known in the Central Indo-Pacific fossil record since the late Miocene of Indonesia (Bromfield, 2013). Lobophyllia hemprichii is widely distributed throughout the modern Central Indo-Pacific and is frequently a dominant species (Veron, 2000).

\section{Family MERULINIDAE Verrill, 1865}

Diagnosis. Colonial, with intra- and/or extracalicular budding; attached or free-living. Corallites monomorphic or polymorphic; sometimes with monticules. Corallites discrete (one to three centers), uniserial or organically united. Walls fused, or with varying amount of costate or spinose coenosteum. Calice of varying width $(<4$ to $>15 \mathrm{~mm}$ ) and relief $(<3$ to $>6 \mathrm{~mm}$ ). Costosepta may be confluent. Septa in varying number of cycles. Free septa 
may be present. Septal spacing varies. Costosepta may be equal or unequal in relative thickness. Columellae of varying sizes relative to calice width, and may be trabecular or lamellar; continuous or discontinuous amongst adjacent corallites. Paliform (uniaxial) lobes may be weak/moderate or well-developed. Septal (multiaxial) lobes may be present. Epitheca and endotheca developments vary amongst species (Huang et al., 2014).

\section{Genus ASTREA Lamarck, 1801}

Type species. Madrepora rotulosa Ellis and Solander, 1786 (type by original designation).

Diagnosis. Merulinidae, which are colonial, with extracalicular budding. Corallites monomorphic and discrete (one to three centers). Coenosteum costate, moderate amount ( $<$ corallite diameter). Calice width medium (4-15 mm), with medium relief (3-6 mm). Costosepta not confluent. Septa in three cycles (24- 36 septa). Free septa present, regular or irregular. Septa spaced six to 11 septa per $5 \mathrm{~mm}$. Costosepta unequal in relative thickness. Columellae trabecular and spongy ( $>$ three threads), $<1 / 4$ of calice width. Paliform (uniaxial) lobes well-developed. Epitheca well-developed and endotheca low-moderate (tabular) (Huang et al., 2014).

Occurrence and distribution. Triassic - recent, worldwide but mostly Indo-Pacific. Oldest record in the Central Indo-Pacific, early Miocene, Fiji (Bromfield, 2013).

\section{Astrea sp. A}

Figure 5.1

Material and occurrence. Calagasan Formation: QMF58491, QMF58492. Chattian. Argao, Cebu, Philippines (CF7).

Description. Colonies encrusting to massive. Corallites monomorphic and discrete (monocentric). Coenosteum costate, moderate amount (< corallite diameter). Calice width $7.72-11.37 \mathrm{~mm}$. Costosepta not confluent. Septa in three cycles $(24-36$ septa). Free septa irregular. Septa spaced eight to 11 septa per $5 \mathrm{~mm}$. Costosepta unequal in thickness. Columellae trabecular and spongy, $<1 / 4$ of calice width.

Remarks. Studied material shows no preservation of corallum or corallite relief. Studied material is potentially the oldest known fossil record of this genus in the Central Indo-Pacific, however, because of the recent changes in the genera nomenclature within the family Merulinidae (Huang et al., 2014), this cannot be confirmed without detailed revision of nomenclature of known merulinids from the region, nor can a species name be assigned.

\section{Astrea sp. B}

Figure 5.2

Material and occurrence. Butong Limestone Formation: QMF58494. Chattian. Argao, Cebu, Philippines (BLF4).

Description. Colony encrusting. Corallites monomorphic and discrete (monocentric). Coenosteum costate, moderate amount (< corallite diameter). Calice width $4.47-9.28 \mathrm{~mm}$. Costosepta not confluent. Septa in three cycles ( $24-36$ septa). Septa spaced eight to 12 septa per $5 \mathrm{~mm}$. Costosepta unequal in thickness. Columellae trabecular and spongy, $<1 / 4$ of calice width.

Remarks. Because of the recent changes in the genera nomenclature within the family Merulinidae (Huang et al., 2014), a species name cannot be assigned without detailed revision of nomenclature of known merulinids from the region. In comparison to Astrea sp. A, Astrea sp. B has smaller corallites with slightly $(<1 \mathrm{~mm})$ elevated wall. Astrea sp. B corallites are more widely spaced (costate coenosteum still < corallite diameter) and costosepta are well-preserved and prominent (Table 3).

\section{Astrea sp. C \\ Figure 5.3}

Material and occurrence. Subis Limestone: QMF58498, QMF58499. Aquitanian. Niah, Sarawak, Malaysia (SL1).

Description. Colonies massive, with extracalicular budding. Corallites monomorphic and discrete (monocentric). Coenosteum costate, moderate amount (< corallite diameter). Calice width 5.19 $10.73 \mathrm{~mm}$. Costosepta not confluent. Septa in three cycles (24 - 36 septa). Free septa irregular. Septa spaced six to 11 septa per $5 \mathrm{~mm}$. Costosepta unequal in thickness. Columellae trabecular and spongy, $<1 / 4$ of calice width.

Remarks. Because of the recent changes in the genera nomenclature within the family Merulinidae (Huang et al., 2014), a species name cannot be assigned without detailed revision of nomenclature of known merulinids from the region. In corallite size Astrea sp. C is similar to Astrea sp. A, but it is more similar to Astrea sp. B in the spacing between the corallites and pronounced costosepta (Table 3). However, comparatively poor preservation of Astrea sp. A makes the comparison between the three morphospecies inconclusive. 

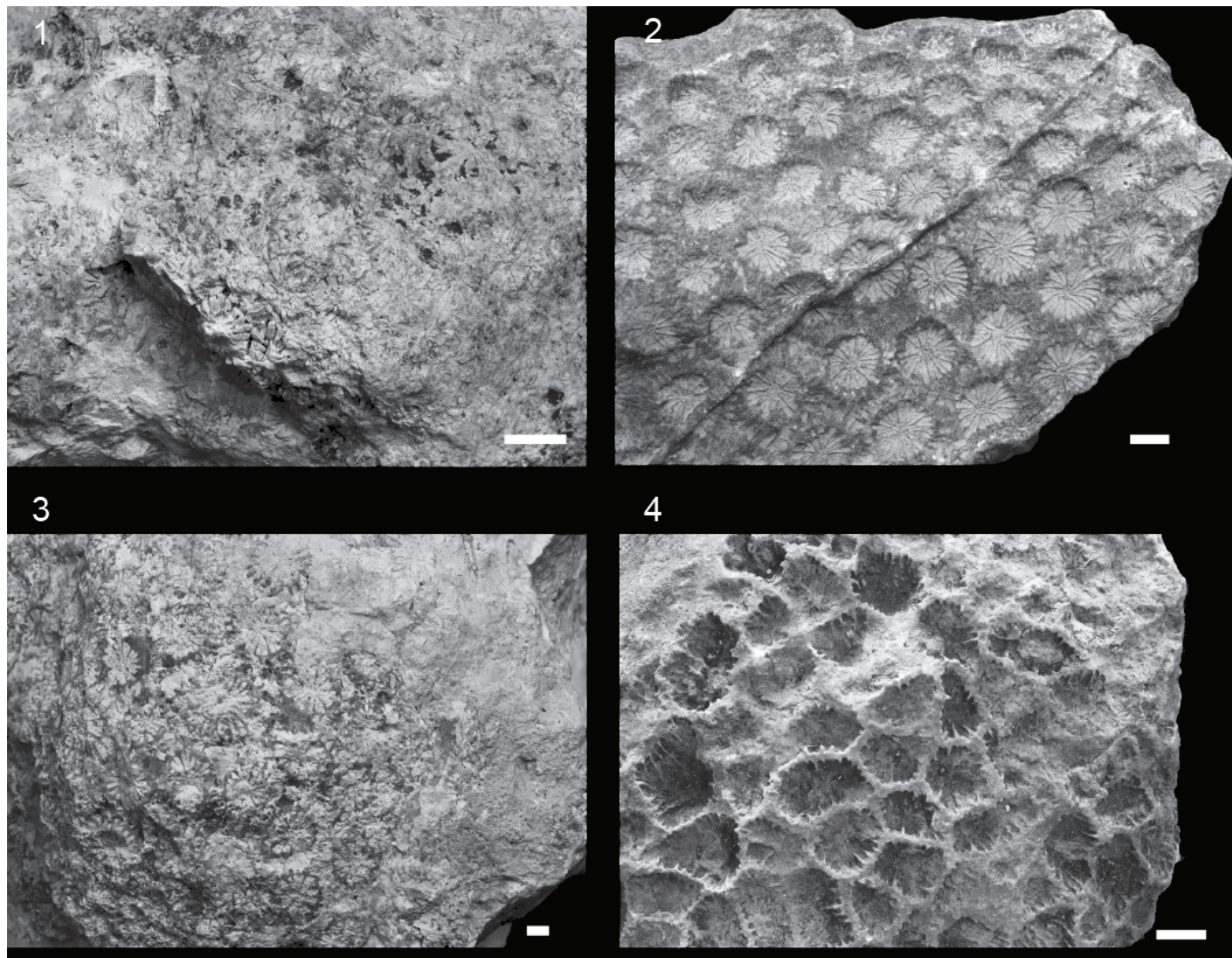

\section{5}
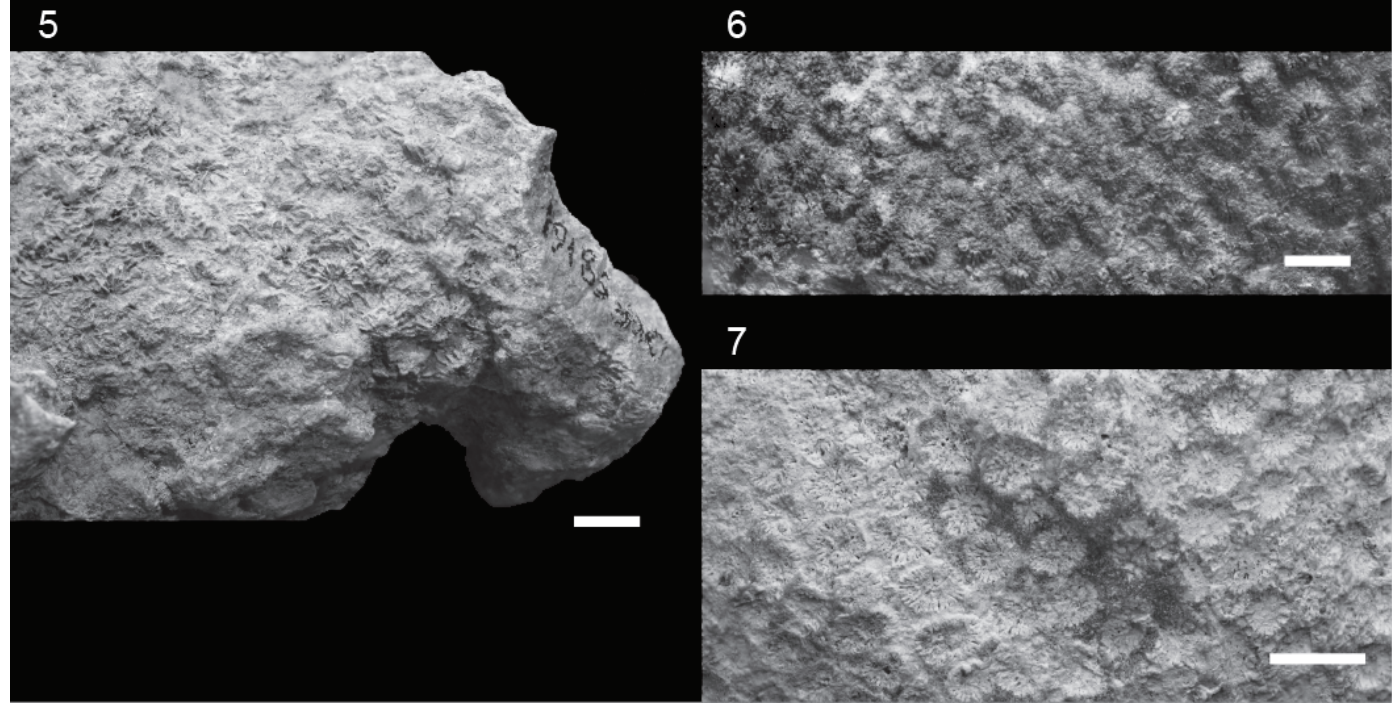

FIGURE 5. 1) Astrea sp. A, QMF58492, Calagasan Formation (late Oligocene - middle Chattian), Cebu. Encrusting to massive colony with monocentric corallites and no relief preserved. 2) Astrea sp. B, QMF58494, Butong Formation (late Oligocene - late Chattian), Cebu. Encrusting colony with slightly elevated corallite walls. 3) Astrea sp. C, QMF58498, Subis Limestone (early Miocene - Aquitanian), Sarawak. Massive colony with monocentric corallites and sometimes visible costosepta. 4) Coelastrea sp. A, QMF58206, Butong Formation (late Oligocene - late Chattian), Cebu. Encrusting to massive colony with corallites polygonal and irregular in outline. 5-6) Cyphastrea cf. serailia, massive colonies with spinose coenosteum and small $(<4 \mathrm{~mm})$, monocentric corallites. Examples here show variation in preservation of coenosteum structure and septa: QMF58161, Butong Formation (late Oligocene - late Chattian), Cebu (5); QMF58166, Butong Formation (late Oligocene - late Chattian), Cebu (6). 7) Cyphastrea sp. A, QMF58497, Calagasan Formation (late Oligocene - middle Chattian), Cebu. Massive colonies with and small $(<\sim 4 \mathrm{~mm})$, monocentric corallites but no preservation of coenosteum texture or corallite relief. Scale bars equal $5 \mathrm{~mm}(1,2,3,5,6,7)$; $10 \mathrm{~mm}(4)$. 
TABLE 3. Comparison of taxonomic differences between morphospecies within genus Astrea.

\begin{tabular}{|c|c|c|c|c|c|}
\hline Morphospecies & Colony shape & $\begin{array}{l}\text { Average corallite } \\
\text { width }(\mathrm{mm})\end{array}$ & $\begin{array}{l}\text { Coenosteum } \\
\text { amount }\end{array}$ & $\begin{array}{l}\text { Number of septa } \\
\text { per } 5 \mathrm{~mm}\end{array}$ & $\begin{array}{l}\text { Preservation } \\
\text { remarks }\end{array}$ \\
\hline Astrea sp. A & $\begin{array}{l}\text { encrusting to } \\
\text { massive }\end{array}$ & $7.72-11.37$ & $\begin{array}{l}\text { moderate (<corallite } \\
\text { diameter) }\end{array}$ & eight to 11 & no relief preserved \\
\hline Astrea sp. B & encrusting & $4.47-9.28$ & $\begin{array}{l}\text { moderate }(<\text { corallite } \\
\text { diameter) but more widely } \\
\text { than Astrea sp. } 1\end{array}$ & eight to 11 & $\begin{array}{l}\text { slightly }(<1 \mathrm{~mm}) \\
\text { elevated walls }\end{array}$ \\
\hline Astrea sp. C & massive & $5.19-10.73$ & $\begin{array}{l}\text { moderate (<corallite } \\
\text { diameter) }\end{array}$ & six to 11 & $\begin{array}{l}\text { some relief } \\
\text { preserved, poorly }\end{array}$ \\
\hline
\end{tabular}

\section{Genus COELASTREA Verrill, 1866}

Type species. Coelastrea tenuis Verrill, 1866 (type by original designation).

Diagnosis. Merulinidae, which are colonial, with intracalicular budding. Corallites monomorphic and discrete (one to three centers). Coenosteum costate, limited amount (includes double wall) or fused walls. Calice width medium $(4-15 \mathrm{~mm})$, with medium relief $(3-6 \mathrm{~mm})$. Costosepta not confluent. Septa in $\geq$ four cycles ( $\geq 48$ septa). Free septa regular. Septa spaced six to 11 septa per $5 \mathrm{~mm}$. Costosepta equal in relative thickness. Columellae trabecular and spongy ( $>$ three threads), $<1 / 4$ of calice width, and continuous amongst adjacent corallites. Septal (multiaxial) lobes well-developed. Epitheca well-developed and endotheca low-moderate (tabular) (Huang et al., 2014).

Occurrence and distribution. Miocene - recent, Red Sea but mostly Indo-Pacific in tropical and sub-tropical regions. Oldest record in the Central Indo-Pacific, late Miocene, Indonesia (Umbgrove, 1945).

\section{Coelastrea sp. A}

Figure 5.4

Material and Occurrence. Butong Limestone Formation: QMF58206, QMF58370, QMF58374, QMF58119. Chattian. Argao, Cebu, Philippines (BLF2 and BLF4).

Description. Colonies encrusting to massive. Corallites monomorphic and discrete (one to three centers), polygonal and irregular in outline. Coenosteum costate, limited amount (double or fused walls). Calice width $6.14-13.73 \mathrm{~mm}$, with medium relief $(3.02-4.54 \mathrm{~mm})$. Costosepta not confluent. Septa in $\geq$ four cycles ( $\geq 48$ septa). Free septa regular. Septa spaced six to 11 septa per 5 $\mathrm{mm}$. Costosepta equal in relative thickness.

Remarks. Studied material is similar to extant species Coelastrea tenuis in colony shape, growth form and corallite appearance. Due to poor preservation of the studied material, characters needed for identifying it as C. tenuis, such as fine details of septa and columella and presence of pali and disepiments (Verrill, 1866), are not available. Studied material is potentially the oldest known fossil record of this genus in the Central Indo-Pacific, however, due to the recent changes in the genera nomenclature within the family Merulinidae (Huang et al., 2014), this cannot be confirmed without detailed revision of nomenclature of already known merulinids from the region. Modern distribution and abundance of this species within the Central IndoPacific is uncertain due to potential misidentifications in the past (Huang et al., 2014).

\section{Genus CYPHASTREA Milne Edwards and Haime, 1848}

Type species. Astraea microphthalma Lamarck, 1816 (type by subsequent designation).

Diagnosis. Merulinidae, which are colonial, with extracalicular budding. Corallites monomorphic and discrete (one to three centers). Coenosteum generally spinose and moderate in amount $(<$ corallite diameter). Calice width small $(<4 \mathrm{~mm})$, with low relief $(<3 \mathrm{~mm})$. Costosepta not confluent. Septa in $\leq$ three cycles ( $\leq 36$ septa). Free septa regular. Septa spaced $>11$ septa per $5 \mathrm{~mm}$. Costosepta unequal in relative thickness. Columellae trabecular but compact (one to three threads), < 1/4 of calice width, and discontinuous amongst adjacent corallites. Paliform (uniaxial) lobes weak or moderate. Epitheca well-developed and endotheca low-moderate (tabular) (Huang et al., 2014).

Occurrence and distribution. Eocene - recent, worldwide (mostly Indo-Pacific). Oldest record in the Central Indo-Pacific, late Eocene, Indonesia (Gerth, 1933).

Cyphastrea cf. serailia (Forskål, 1775)

Figure 5.5-6

1775 Madrepora serailia Forskål, p. 135.

1886 Cyphastrea brueggemanni Quelch, p. 107, pl. 4, figs. 3-3a.

1904 Cyphastrea suvadivae Gardiner, p. 780. 
1977 Cyphastrea serailia (Forskå); Veron et al., p. 169 , figs. 330-341.

2000 Cyphastrea serailia (Forskål); Veron, p. 242 (vol. 2).

2013 Cyphastrea serailia (Forskål); Bromfield, p. 28, pl. 13, fig. 5.

Type locality. Red Sea (Veron, 1986).

Material and occurrence. Butong Limestone Formation: QMF58161, QMF58162, QMF58163, QMF58164, QMF58165, QMF58166, QMF58167, QMF58168, QMF58169; Calagasan Formation: QMF58171, QMF58172, QMF58173, QMF58174. Chattian. Argao, Cebu, Philippines (BLF2, BLF4, CF4, and CF7).

Description. Colonies massive, with extracalicular budding. Corallites monomorphic and discrete (monocentric). Coenosteum spinose and moderate in amount (< corallite diameter). Calice width 2.08 - $3.94 \mathrm{~mm}$, with low relief $(<3 \mathrm{~mm})$. Costosepta not confluent. Septa in $\leq$ three cycles ( $\leq 36$ septa). Septa spaced eight to 10 septa per $2.5 \mathrm{~mm}$. Costosepta unequal in relative thickness. Columellae trabecular but compact (one to three threads), <1/4 of calice width, and discontinuous amongst adjacent corallites. Paliform lobes moderate.

Remarks. Studied material is similar in colony shape, growth form, and corallite appearance and size to Cyphastrea serailia, a species common in the Central Indo-Pacific fossil record since the early Miocene (Felix, 1915; Umbgrove, 1946a; Osberger, 1954a; Boekschoten et al., 1989; Bromfield, 2013). Thus, the studied material is the oldest fossil record of this species. Cyphastrea serailia is also common and widely distributed throughout the modern Central Indo-Pacific (Veron, 2000). This species is known to show skeletal variations related to the enviroment in which it lives (Veron et al., 1977). This variation and probably its inaccessible literature has led to description of $C$. brueggemanni by Quelch, 1886, and C. suvadivae by Gardiner, 1904. However, these species correspond with descriptions of $C$. serailia. Two Fungia spp. individuals (QMF58144 and QMF58145) are preserved on the same limestone block as sample QMF58173.

\section{Cyphastrea sp. A}

Figure 5.7

Material and occurrence. Calagasan Formation: QMF58497. Chattian. Argao, Cebu, Philippines (CF7).

Description. Colony massive, with extracalicular budding. Corallites monomorphic and discrete (monocentric). Coenosteum moderate in amount (< corallite diameter). Calice width $2.04-4.11 \mathrm{~mm}$.
Costosepta not confluent. Septa in $\leq$ three cycles ( $\leq 36$ septa). Free septa regular. Septa spaced 1015 septa per $2.5 \mathrm{~mm}$. Costosepta unequal in relative thickness. Columellae trabecular but compact, $<1 / 4$ of calice width, and discontinuous amongst adjacent corallites. Paliform lobes weak.

Remarks. Studied material shows no preservation of coenosteum texture or corallite relief making the identification beyond the genus level difficult. Detailed comparison between the two Cyphastrea morphospecies is challenging as their preservations differ. However, in comparison to $C$. cf. serailia, Cyphastrea sp. B has larger corallites and less pronounced paliform lobes.

\section{Genus DIPSASTRAEA de Blainville, 1830}

Type species. Madrepora favus Forskål, 1775 (type by subsequent designation).

Diagnosis. Merulinidae, which are colonial, with intracalicular budding. Corallites monomorphic and discrete (one to three centers). Coenosteum costate, moderate amount (< corallite diameter), and limited (includes double wall) in some species. Generally, calice width medium (4 -15 mm), with medium relief $(3-6 \mathrm{~mm})$. Costosepta not confluent. Septa in three cycles (24 - 36 septa). Free septa present but generally irregular. Septa spaced six to 11 septa per $5 \mathrm{~mm}$. Costosepta equal in relative thickness. Columellae trabecular and spongy ( $>$ three threads), $<1 / 4$ of calice width, and continuous amongst adjacent corallites. Paliform (uniaxial) lobes weak or moderate. Epitheca welldeveloped and endotheca low-moderate (tabular) (Huang et al., 2014).

Occurrence and distribution. Eocene - recent, Indo-Pacific. Oldest record in the Central IndoPacific, Eocene, Marshall Islands (Wells, 1964).

\section{Dipsastraea sp. A \\ Figure 6.1}

Material and occurrence. Calagasan Formation: QMF58185, QMF58186, QMF58187, QMF58188. Chattian. Argao, Cebu, Philippines (CF7).

Description. Colonies massive. Corallites monomorphic and discrete (monocentric). Coenosteum costate, moderate amount (< corallite diameter). Calice width medium $4.67-6.34 \mathrm{~mm}$, with exsert, tubular corallites $(3.05-5.65 \mathrm{~mm})$. Costosepta not confluent. Septa in three cycles (24 - 36 septa). Free septa present and irregular. Septa spaced six to 11 septa per $5 \mathrm{~mm}$. Costosepta equal in relative thickness. Columellae trabecular and spongy, $<1 / 4$ of calice width. Paliform lobes weak or moderate.

Remarks. Studied material is characterized by exsert corallites, a feature unknown among fossil 

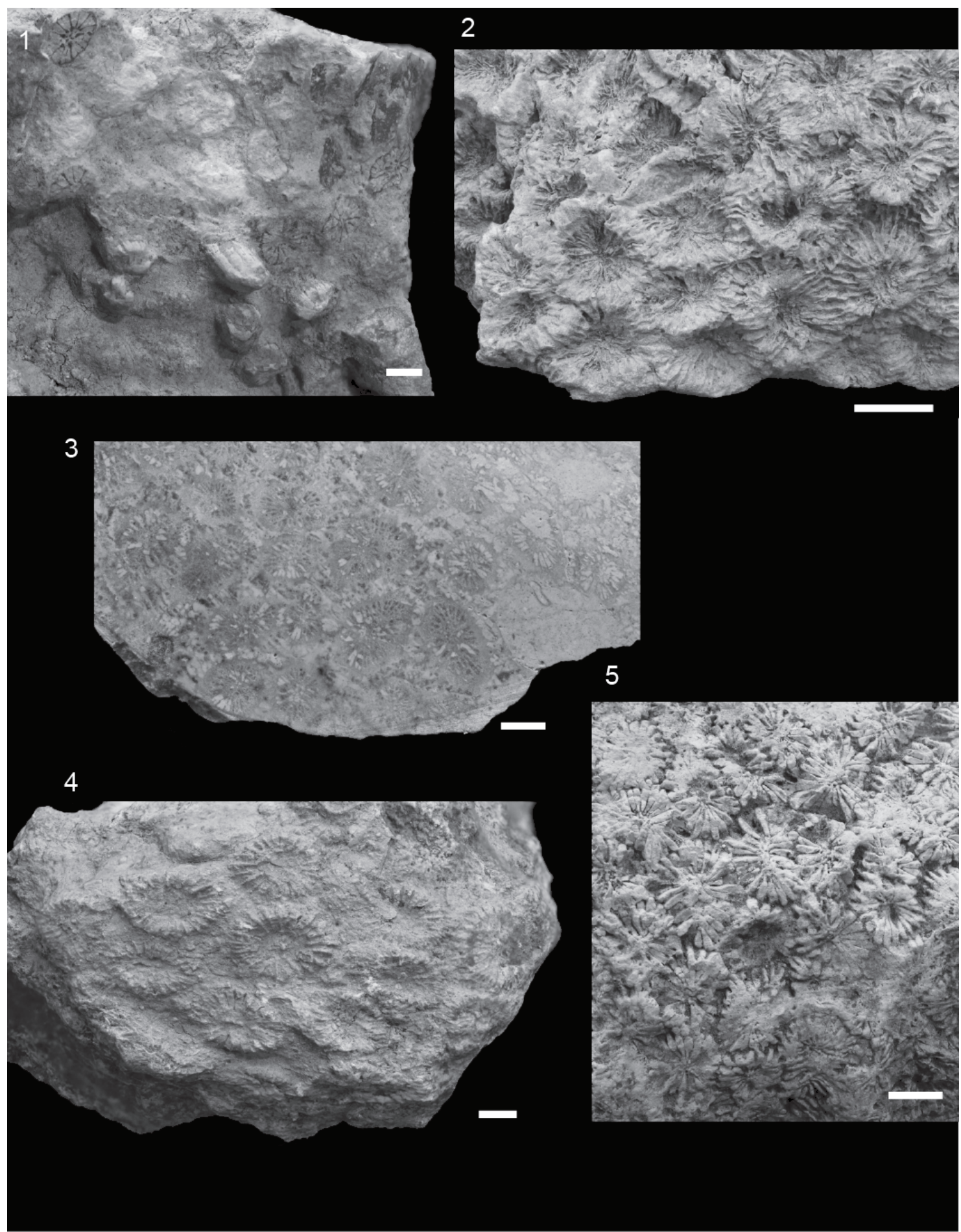

FIGURE 6. 1) Dipsastraea sp. A, QMF58185, Calagasan Formation (late Oligocene - middle Chattian), Cebu. Massive colony with tubular and exsert corallites. 2) Dipsastraea sp. B, QMF58205, Butong Formation (late Oligocene late Chattian), Cebu. Encrusting to massive colony with irregularly-shaped, monocentric corallites and varying amount of coenosteum (moderate amount, < corallite diameter). 3-4) Dipsastraea cf. speciosa, massive colony with monocentric corallites, round in outline. Examples here show variation in preservation of the morphospecies in different lithologies: QMF58309, Subis Limestone (early Miocene - Aquitanian), Sarawak. Cross-section through the specimen (3); QMF58298, Butong Formation (late Oligocene - late Chattian), Cebu (4). 5) Favites sp. A, QMF58213, Calagasan Formation (late Oligocene - middle Chattian), Cebu. Massive colony with round to elliptical corallites with visible budding. Scale bars equal $5 \mathrm{~mm}(1,3,4,5) ; 10 \mathrm{~mm}(2)$. 
TABLE 4. Comparison of taxonomic differences between morphospecies within genus Dipsastraea.

\begin{tabular}{|c|c|c|c|c|c|}
\hline Morphospecies & $\begin{array}{l}\text { Colony } \\
\text { shape }\end{array}$ & $\begin{array}{l}\text { Average corallite } \\
\text { width }(\mathrm{mm})\end{array}$ & Corallite outline & Corallite relief & Paliform lobes \\
\hline $\begin{array}{l}\text { Dipsastraea cf. } \\
\text { speciosa }\end{array}$ & massive & $4.22-9.3$ & round & $\sim 3$ & weak to moderate \\
\hline Dipsastraea sp. A & massive & $4.67-6.34$ & tubular, exsert & $3.05-5.65$ & weak to moderate \\
\hline Dipsastraea sp. B & $\begin{array}{l}\text { encrusting to } \\
\text { massive }\end{array}$ & $5.94-13.64$ & irregular & $3.23-5.51$ & weak \\
\hline
\end{tabular}

Dipsastraea species. Dipsastraea laddi, an extant species rare yet widely distributed throughout the modern Central Indo-Pacific (Veron, 2000), is the only species with this feature. However, $D$. laddi has larger (on average $10 \mathrm{~mm}$ in diameter) and more exsert (on average $10 \mathrm{~mm}$ ) corallites than Dipsastraea sp. A. Moreover, D. laddi is characterized by exsert septa with strongly dentate margins and spiny costae (Wells, 1954), characters not present in Dispastrea sp. A. Due to the recent changes in the generic nomenclature within the family Merulinidae (Huang et al., 2014), fossil species of Barabattoia, Favia and Favites were also reviewed for exsert corallites but no taxon resembling the studied material has been found.

\section{Dipsastraea sp. B}

Figure 6.2

Type locality. Milne Bay, eastern Papua New Guinea (Veron, 2000).

Material and occurrence. Butong Limestone Formation: QMF58205. Chattian. Argao, Cebu, Philippines (BLF4).

Description. Colony encrusting to massive. Corallites monomorphic and discrete (monocentric). Coenosteum costate, moderate amount (varies in width but always < corallite diameter). Calice width 5.94 - $13.64 \mathrm{~mm}$, with medium relief (3.23-5.51 $\mathrm{mm}$ ). Costosepta not confluent. Septa in three cycles (24 - 36 septa). Free septa present and irregular. Septa spaced six to 10 septa per $5 \mathrm{~mm}$. Costosepta equal in relative thickness. Columellae trabecular and spongy, < 1/4 of calice width. Paliform lobes weak.

Remarks. In its colony shape, corallite outline and arrangement studied material resembles extant Dipsastraea truncata, common species widely distributed throughout the modern Indo-Pacific (Veron, 2000). Corallite sizes of Dipsastraea sp. B and $D$. truncata are similar but upper limit of the $D$. truncata corallites (with $9 \mathrm{~mm}$ ) is lower/smaller (Veron, 2000, 2002). Although both species are charasterized by inclined corallites, the lower part of the wall of inclined corallites in $D$. truncata is commonly immersed, giving the upper part a hooded appearance (Veron, 2000, 2002), which does not occur in Dipsastraea sp. B. In the studied material, corallite outline and inclination, as well as amount of coenosteum, vary within colonies. These types of variation are typical for colony edges. Despite the corallite relief of Dipsastraea $\mathrm{sp}$. B having similar values as the calice relief of Dipsastraea sp. A, these are clearly separate morphospecies as, in comparison to Dipsastraea sp. A, Dipsastraea sp. B has up to two times larger, nontubulate corallites (Table 4).

Dipsastraea cf. speciosa (Dana, 1846)

Figure 6.3-4

1846 Astraea speciosa Dana, p. 220, p. 11 fig. 1.

2000 Favia speciosa (Dana); Veron, p. 108 (vol. 3).

2014 Dipsastraea speciosa (Dana); Huang et al., p. 309.

Type locality. East Indies (Dana, 1846).

Material and occurrence. Butong Limestone Formation: QMF58297, QMF58298; Calagasan Formation: QMF58301, QMF58302, QMF58303; Subis Limestone: QMF58189, QMF58190, QMF58191, QMF58194, QMF58195, QMF58196, QMF58197, QMF58198, QMF58199, QMF58203, QMF58204, QMF58304, QMF58305, QMF58306, QMF58307, QMF58308, QMF58309, QMF58310, QMF58311, QMF58312, QMF58313, QMF58338, QMF58375; Trankalan/Binaguiohan Limestone: QMF58299, QMF58300. Chattian to Aquitanian. Argao, Cebu, Philippines (BLF4, CF6, and CF7); Candoni, Negros (Oriental) Philippines (TBL); Niah, Sarawak, Malaysia (SL1 and SL2).

Description. Colonies massive, with intracalicular budding. Corallites monomorphic and discrete (monocentric). Coenosteum costate, moderate amount (< corallite diameter). Calice width $4.22-$ $9.3 \mathrm{~mm}$, with medium relief $(\sim 3 \mathrm{~mm})$. Costosepta not confluent. Septa in three cycles $(24-36$ septa). Free septa present and irregular. Septa spaced six to 11 septa per $5 \mathrm{~mm}$. Costosepta equal in relative thickness. Columellae trabecular and spongy ( $>$ three threads), $<1 / 4$ of calice width. Paliform lobes weak or moderate. 
Remarks. Studied material varies in preservation quality: in some samples (mostly those preserved in dense limestone matrix) the taxonomic characters are only visible from the cross-section (e.g., QMF58309) while others even have the colony relief preserved (e.g., QMF58298). Despite the differences in preservation, all samples assigned to Dipsastraea cf. speciosa due to resemblance in colony shape, growth form, corallite size and appearance, as well as septal arrangement. Studied material resembles drawings of Astraea speciosa by Dana, 1846, despite the corallite size of $A$. speciosa being somewhat unclear due to usage of archaic and poorly defined unit of length, lines. Corallite size, septal arrangement and variation of coenosteum amount in Favia speciosa described by Veron, 2000 match studied material. Because of recent changes in the generic nomenclature within the family Merulinidae (Huang et al., 2014), Favia speciosa is now known as Dipsastraea speciosa. Intracalicular budding characteristic for Dipsastraea visible in sample QMF58309. Dipsastraea speciosa is known from the Central Indo-Pacific fossil record since the early Miocene (Jordan and Abdullah, 1992) and is very common and widely distributed throughout the modern Indo-Pacific (Veron, 2000). In comparison to D. sp. B, D. cf. speciosa has smaller and more regularly (circular) shaped corallites (Table 4).

\section{Genus FAVITES Link, 1807}

Type species. Favites astrinus Link, 1807 (type by original designation).

Diagnosis. Merulinidae, which are colonial, with intra- and extracalicular budding. Corallites monomorphic and discrete (one to three centers). Coenosteum costate, limited amount (includes double wall) or fused walls. Calice width medium (4 - $15 \mathrm{~mm}$ ), but may be larger (> $15 \mathrm{~mm}$ ), with medium relief ( $3-6 \mathrm{~mm}$ ). Costosepta may be confluent. Septa generally in $\geq$ four cycles ( $\geq 48$ septa). Free septa present and irregular. Septa spaced six to 11 septa per $5 \mathrm{~mm}$. Costosepta unequal in relative thickness. Columellae trabecular and spongy ( $>$ three threads), $<1 / 4$ of calice width, and continuous amongst adjacent corallites. Paliform (uniaxial) lobes weak to well-developed. Epitheca welldeveloped and endotheca generally abundant (vesicular) (Huang et al., 2014).

Occurrence and distribution. Jurassic - recent, worldwide in tropical and sub-tropical regions. Oldest record in the Central Indo-Pacific, late Eocene, Indonesia (Wilson and Rosen, 1998).

\section{Favites sp. A}

Figure 6.5

Material and occurrence. Calagasan Formation: QMF58208, QMF58209, QMF58213, QMF58215, QMF58217. Chattian. Argao, Cebu, Philippines (CF6 and CF7).

Description. Colonies massive, with intra- and extracurriular budding. Corallites monomorphic and discrete (one to three centers). Coenosteum costate, limited amount (includes double wall). Calice width $6.70-9.26 \mathrm{~mm}$. Septa generally in $\geq$ four cycles ( $\geq 48$ septa). Free septa present and irregular. Septa spaced six to 11 septa per $5 \mathrm{~mm}$. Costosepta unequal in relative thickness. Columellae trabecular and spongy ( $>$ three threads), $<1 / 4$ of calice width. Paliform lobes moderate.

Remarks. Studied material shows no preservation of the colony relief as the skeleton itself is dissolved and the space between septa is infilled with lithified sediment. Nevertheless, the corallite and septal arrangements are visible. This together with the colony shape and growth form correspond with genus Favites. Although the corallite size of Favites sp. A is similar to the size of Favites cf. pentagona tenuis corallite, the outline appears to be round and elliptical rather than irregular as in $F$. cf. pentagona tenui, making this a separate species (Table 5).

\section{Favites cf. chinensis (Verrill, 1866)}

Figure 7.1

1866 Prionastraea chinensis Verrill, p. 35.

1977 Favites chinensisi (Verrill); Veron et al., p. 53, figs. 83-88.

2000 Favites chinensisi (Verrill); Veron, p. 143 (vol. 3).

Type locality. Hong Kong (Verrill, 1866).

Material and occurrence. Butong Limestone Formation: QMF58207; Calagasan Formation: QMF58210, QMF58211, QMF58212, QMF58214, QMF58216, QMF58218. Chattian. Argao, Cebu, Philippines (BLF4, CF6, and CF7).

Description. Colonies encrusting to massive. Corallites monomorphic and discrete (monocentric). Coenosteum costate, limited amount (includes double wall). Corallites polygonal and irregular in outline. Calice width 10.94 - $14.16 \mathrm{~mm}$, with medium relief $(3-6 \mathrm{~mm})$. Septa generally in $\geq$ four cycles ( $\geq 48$ septa). Free septa present and irregular. Septa spaced seven to 11 septa per $5 \mathrm{~mm}$. Costosepta unequal in relative thickness. Columellae trabecular and spongy, $<1 / 4$ of calice width.

Remarks. Studied material resembles extant Favites chinensis in its colony shape and corallite 


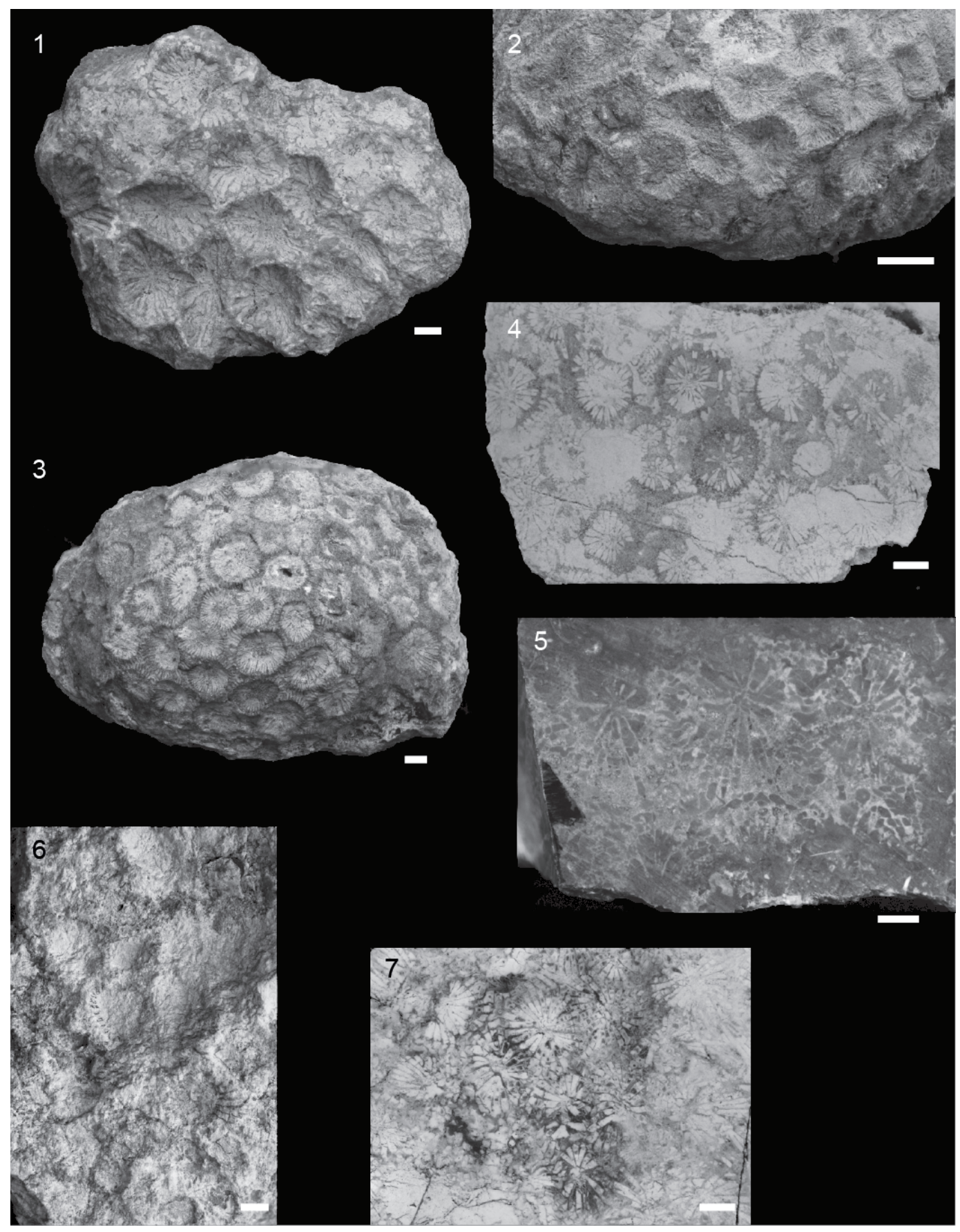

FIGURE 7. 1) Favites cf. chinensis, QMF58206, Calagasan Formation (late Oligocene - middle Chattian), Cebu. Encrusting to massive colony with monocentric corallites, polygonal and irregular in outline. 2) Favites cf. pentagona tenuis, QMF58296, Calagasan Formation (late Oligocene - middle Chattian), Cebu. Encrusting to massive colony with discrete (one to three centers) corallites, irregular in outline. 3) Favites sp. B, QMF58495, Calagasan Formation (late Oligocene - middle Chattian), Cebu. Massive colonies with monocentric corallites, round in outline. 4-7) Favites spp., Massive colonies with monocentric circular corallites, round in outline, and well-developed costosepta. Examples here show variation in preservation between different lithologies: QMF58321, Subis Limestone (early Miocene Aquitanian), Sarawak. Cross-section through the specimen. Intracalicular budding visible (4); QMF58333, Melinau Limestone (early Miocene - Aquitanian), Sarawak. Costosepta well-preserved (5); QMF58316, Subis Limestone (early Miocene - Aquitanian), Sarawak. Surface of the specimen with visible relief (6); QMF58316, Subis Limestone (early Miocene - Aquitanian), Sarawak. Cross-section through the specimen (7). Scale bars equal $5 \mathrm{~mm}(1,3,4,5,6,7) ; 10$ $\mathrm{mm}(2)$. 
TABLE 5. Comparison of taxonomic differences between morphospecies within genus Favites.

\begin{tabular}{llclll}
\hline Morphospecies & \multicolumn{1}{c}{ Colony shape } & $\begin{array}{c}\text { Average } \\
\text { corallite width } \\
(\mathbf{m m})\end{array}$ & Corallite discrete & Corallite outline & $\begin{array}{c}\text { Number of septa } \\
\text { per 5 mm }\end{array}$ \\
\hline Favites cf. chinensis & encrusting to massive & $10.94-14.16$ & monocentric & $\begin{array}{l}\text { polygonal and } \\
\text { irregular }\end{array}$ & seven to 11 \\
$\begin{array}{l}\text { Favites cf. } \\
\text { pentagona tenuis }\end{array}$ & encrusting to massive & $6.07-10.35$ & one to three centers & irregular & six to ?24 \\
$\begin{array}{l}\text { Favites sp. A } \\
\text { Favites sp. B }\end{array}$ & massive & $6.70-9.26$ & one to three centers & round to elliptical & six to 11 \\
\hline
\end{tabular}

outline, arrangement and size (Verrill, 1866; Veron et al., 1977). Veron et al., 1977, report and illustrate the variation in the corallite outlines. The studied material resembles most specimens from Three Isles, Australia. In the fossil record, F. chinensis is known from Oligocene of Sabah, Malaysia (McMonagle, 2012). Thus, herein studied material together with the $F$. chinensis records from Sabah are the oldest known fossil record from the Central Indo-Pacific. Favites chinensis is uncommon yet widely distributed throughout the modern IndoPacific (Veron, 2000). Due to the poor preservation of the surface, sample QMF58218 was cut and taxonomic characters exposed on the cross-section. Samples QMF58210 and QMF58211 are preserved on the same limestone block as Galaxea sp. A colonies (QMF58141 and QMF 58142).

Favites cf. pentagona tenuis (Umbgrove, 1946)

Figure 7.2

1946b Favites pentagona tenuis Umbgrove, p. 526, pl. 77, fig. 7.

Type locality. Tjisande, Java, Indonesia (Umbgrove, 1946b).

Material and occurrence. Calagasan Formation: QMF58296. Chattian. Argao, Cebu, Philippines (CF4).

Description. Colony encrusting to massive. Corallites monomorphic and discrete (one to three centers). Coenosteum costate, limited amount (includes double wall). Corallites irregular in outline. Calice width $6.07-10.35 \mathrm{~mm}$, with medium relief $(3-6 \mathrm{~mm})$. Septa generally in $\geq$ four cycles $(\geq 48$ septa). Free septa present and irregular. Septa spaced six to 24 septa per $5 \mathrm{~mm}$. Costosepta unequal in relative thickness. Columellae trabecular and spongy ( $>$ three threads), < 1/4 of calice width.

Remarks. Despite maximal corallite size of studied material larger than reported for Favites pentagona tenuis corallite size (max $7 \mathrm{~mm}$ ), studied material resembles $F$. pentagona tenuis in colony shape and corallite outline and arrangement. Prior to description of this material, F. pentagona (tenuis) has been known in the Central Indo-Pacific fossil record since the middle Miocene (Umbgrove, 1945; Bromfield, 2013). Favites pentagona is common and widely distributed throughout the modern IndoPacific (Veron, 2000). Studied F. cf. pentagona tenuis has similar sized corallites as Favites sp. A but septa appear finer and more numerous. Despite having irregularly shaped corallites, F. cf. pentagona tenuis has less angular and smaller corallites than $F$. cf. chinensis.

\section{Favites sp. B}

Figure 7.3

Material and occurrence. Butong Limestone Formation: QMF58493; Calagasan Formation: QMF58495, QMF58496. Chattian. Argao, Cebu, Philippines (BLF4 and CF4).

Description. Colonies massive, with extracalicular budding. Corallites monomorphic and discrete (monocentric). Coenosteum costate, limited amount (includes double wall) to moderate. Calice width $4.14-9.12 \mathrm{~mm}$. Costosepta not confluent. Septa in $\geq$ four cycles ( $\geq 48$ septa). Free septa present and irregular. Septa spaced eight to 11 septa per $5 \mathrm{~mm}$. Costosepta unequal in relative thickness. Columellae trabecular and spongy, $<1 / 4$ of calice width.

Remarks. Favites sp. A, F. cf. pentagona tenuis and Favites sp. B have corallites of similar size but Favites sp. B has more regularly shaped and rounded corallites which distinguishes it from both F. cf. pentagona tenuis and Favites sp. B (Table 5). Moreover, in comparison to Favites sp. A, Favites sp. B has finer septa.

Favites spp.

Figure 7.4-7

Material and occurrence. Melinau Limestone: QMF58328, QMF58329, QMF58330, QMF58331, QMF58332, QMF58333, QMF58334; Subis Limestone: QMF58314, QMF58315, QMF58316, QMF58317, QMF58318, QMF58319, QMF58320, 
QMF58321, QMF58322, QMF58323, QMF58324, QMF58325, QMF58326, QMF58327. Aquitanian. Gunung Mulu, Sarawak, Malaysia (ML); Niah, Sarawak, Malaysia (SL1 and SL2).

Remarks. Studied material comprised of encrusting to massive colonies with medium relief $(3-6$ $\mathrm{mm}$ ). Substantial variation in preservation of studied material (see QMF58321, QMF58326, QMF58328, QMF58333) prevents identification beyond the genus level. However, all samples have similar corallite size $(5.17-11.86 \mathrm{~mm})$ and septal arrangement ( $\geq 48$ septa, six to 11 septa per $5 \mathrm{~mm}$ ), therefore, are considered Favites spp. Intracalicular budding is visible in sample QMF58321 as is variation in corallite size and amount of coenosteum within the colony.

Genus GONIASTREA Milne Edwards and Haime, 1848

Type species. Astrea retiformis Lamarck, 1816 (type by original designation).

Diagnosis. Merulinidae, which are colonial, with intracalicular budding. Corallites monomorphic and discrete (one to three centers) or uniserial. Walls generally fused. Calice width small to medium ( $\leq$ $15 \mathrm{~mm}$ ), with low to medium relief $(\leq 6 \mathrm{~mm})$. Costosepta generally not confluent. Septa in three cycles (24 - 36 septa). Free septa present, regular or irregular. Septa spaced $\geq$ six septa per $5 \mathrm{~mm}$. Costosepta equal in relative thickness. Columellae trabecular and generally compact, < 1/4 of calice width, and continuous amongst adjacent corallites. Paliform (uniaxial) lobes well-developed, and may be present as septal (multiaxial) lobes. Epitheca well-developed and endotheca low-moderate (tabular) (Huang et al., 2014).

Occurrence and distribution. Cretaceous recent, Tethys and Indo-Pacific. Oldest record in the Central Indo-Pacific, Oligocene, Sabah, Malaysia (McMonagle, 2012).

Goniastrea cf. stelligera (Dana, 1846)

Figure 8.1-2

1846 Orbicella stelligera Dana, p. 216, pl. 10, figs. 9a-9e.

1977 Favia stelligera (Dana); Veron et al., p. 20, figs. 16-22.

2013 Favia stelligera (Dana); Bromfield, p. 32, pl. 16, fig. 6 , pl. 7, fig. 1.

2012 Dipsastraea stelligera (Dana). Budd et al., p. 496.

2014 Goniastrea stelligera (Dana). Huang et al., p. 319, figs. 14j-14l.

Type locality. Fiji (Dana, 1846).
Material and occurrence. Butong Limestone Formation: QMF58175, QMF58176, QMF58177, QMF58178, QMF58179, QMF58180, QMF58181, QMF58182, QMF58183; Calagasan Formation: QMF58170. Chattian. Argao, Cebu, Philippines (BLF4 and CF4).

Description. Colonies encrusting, with intracalicular budding. Corallites monomorphic and discrete (monocentric). Coenosteum costate, moderate amount (< corallite diameter). Corallites irregular in outline. Calice width $1.56-2.69 \mathrm{~mm}$, with low relief ( $3 \mathrm{~mm})$. Costosepta not confluent. Septa in three cycles (24 - 36 septa). Free septa present, regular or irregular. Septa spaced $8-16$ septa per 2.5 $\mathrm{mm}$. Costosepta equal in relative thickness. Columellae trabecular and compact, < 1/4 of calice width. Paliform (uniaxial) lobes well-developed.

Remarks. Studied material comprises encrusting colonies with uneven surface and varying preservation of corallites even on the single colony (e.g., QMF58176). In some, the colony surface is eroded to the point that the low relief corallites look immersed, which is similar to Goniastrea stelligera desribed from Indonesia (Bromfield, 2013). Studied material resembles $G$. stelligera in corallite outlines, moderate amount of coenosteum and uneven colony surface (Veron et al., 1977). Due to revision of the phylogenetic relationships within this group, this species has been first placed in genus Dipsastraea by Budd et al., 2012 and then in genus Goniastrea by Huang et al., 2014. Prior to description of this material G. stelligera has been known from the Central Indo-Pacific fossil record since the early Miocene (Jordan and Abdullah, 1992). This species is common and widely distributed throughout the modern Indo-Pacific (Veron, 2000).

\section{Genus HYDNOPHORA Fischer de Waldheim, 1807}

Type species. Hydnophora demidovii Fischer von Waldheim, 1807 (type by original designation).

Diagnosis. Merulinidae, which are colonial, with intracalicular budding. Corallites monomorphic and uniserial; monticules present. Walls fused. Calice width small to medium ( $\leq 15 \mathrm{~mm}$ ), with low to medium relief $(\leq 6 \mathrm{~mm})$. Costosepta not confluent. Septa in < three cycles (<24 septa). Free septa absent. Septa spaced six to 11 septa per $5 \mathrm{~mm}$. Costosepta equal in relative thickness. Columellae trabecular but compact (one to three threads), $<1 /$ 4 of calice width, and continuous amongst adjacent corallites. Paliform (uniaxial) lobes absent. Epitheca reduced and endotheca sparse (Huang et al., 2014). 


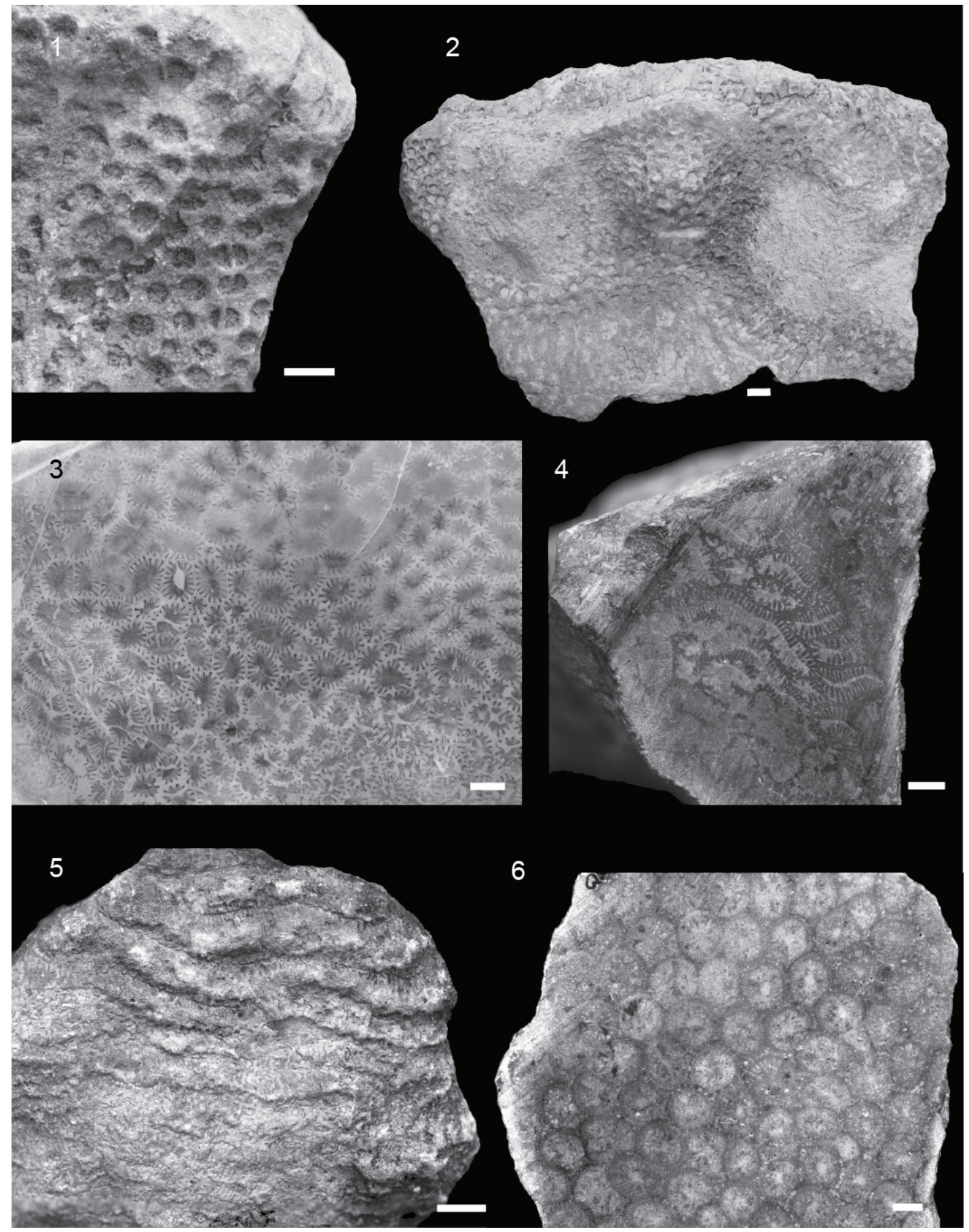

FIGURE 8. 1) Goniastrea cf. stelligera, QMF58175, Butong Formation (late Oligocene - late Chattian), Cebu. Corallites monomorphic and discrete (one to three centers), irregular in outline. 2) Goniastrea cf. stelligera, QMF58167, Butong Formation (late Oligocene - late Chattian), Cebu. Encrusting to massive colony with uneven colony relief. 3) Hydnophora cf. microconos, QMF58230, Subis Limestone (early Miocene - Aquitanian), Sarawak. Cross-section through a massive colony. Monticule outlines visible - note the position of columella and direction of septa. 4-5) Leptoria cf. phrygia, massive to encrusting colony with uniserial corallites (valleys). Examples here show variation in preservation of the morphospecies in different lithologies: QMF58253, Melinau Limestone (early Miocene - Aquitanian), Sarawak. Cross-section through the specimen (4); QMF58243, Butong Formation (late Oligocene - late Chattian), Cebu. Colony with preserved relief (5). 6) Paramontastraea sp. A, QMF58502, Melinau Limestone (early Miocene - Aquitanian), Sarawak. Cross-section through the specimen. Massive colony with densely arranged corallites, round in outline. Scale bars equal $5 \mathrm{~mm}$. 
Occurrence and distribution. Cretaceous recent, worldwide in tropical and sub-tropical regions (mostly Indo-Pacific and Tethys). Oldest record in the Central Indo-Pacific, Oligocene, Sabah, Malaysia (McMonagle, 2012).

Hydnophora cf. microconos (Lamarck, 1816)

Figure 8.3

1786 Madrepora exesa Ellis and Solander, p. 161, pl. 49 fig. 3.

1816 Monticularia microconos Lamarck, p. 251.

1907 Hydnophorella microconos (Lamarck); Bedot, p. 197, pl. 25, figs. 119-122.

1977 Hydnophora microconos (Lamarck); Veron et al., p. 135, figs 225-226.

2000 Hydnophora microconos (Lamarck); Veron, p. 372 (vol. 2).

Type locality. Indo-Pacific (Lamarck, 1816).

Material and occurrence. Butong Limestone Formation: QMF58272; Calagasan Formation: QMF58249, QMF58273, QMF58274, QMF58275, QMF58276, QMF58277, QMF58278, QMF58506, QMF58507, QMF58508, QMF58509; Melinau Limestone: QMF58219, QMF58279, QMF58280, QMF58281, QMF58282, QMF58283, QMF58284, QMF58285, QMF58286, QMF58287, QMF58288, QMF58289, QMF58290, QMF58291, QMF58292, QMF58293; Subis Limestone: QMF58220, QMF58221, QMF58222, QMF58223, QMF58224, QMF58225, QMF58226, QMF58227, QMF58228, QMF58229, QMF58230, QMF58231, QMF58233, QMF58293. Chattian to Aquitanian. Argao, Cebu, Philippines (BLF4, CF6, and CF7); Gunung Mulu, Sarawak, Malaysia (ML); Niah, Sarawak, Malaysia (SL1 and SL2).

Description. Colonies massive, with intracalicular budding. Corallites monomorphic and uniserial; monticules present. Walls fused. Calice width 3.35 - $7.16 \mathrm{~mm}$. Costosepta not confluent. Septa in < three cycles ( $<24$ septa). Free septa absent. Septa spaced six to 11 septa per $5 \mathrm{~mm}$. Costosepta equal in relative thickness. Columellae trabecular but compact, < 1/4 of calice width, and continuous amongst adjacent corallites. Paliform (uniaxial) lobes absent.

Remarks. The surface of the studied material is eroded and poorly preserved, therefore monticules are not preserved. However, in the cross-section (cut parallel to the surface of the colony) the monticule outlines are clearly visible, and their existence is supported by the position of the columella and direction of septa, especially in sample QMF58231. Studied material resembles Hydnophora microconos in its colony shape, growth form, presence of monticules and corallite appearance (Ellis and
Solander, 1786; Lamarck, 1816; Bedot, 1907; Veron et al., 1977; Veron, 2000). Corallite size in studied material can be twice as big as reported by other authors (Bedot, 1907; Veron et al., 1977; Veron, 2000). Due to the poor preservation of the surface, the measurements were taken on the cross-section of the colony, which most likely lead to seemingly larger corallite sizes. In the fossil record, this species is known from Oligocene of Sabah, Malaysia (McMonagle, 2012). Thus, herein studied material together with the $H$. microconos records from Sabah are the oldest known fossil record from the Central Indo-Pacific. Hydnophora microconos is uncommon yet widely distributed throughout the modern Indo-Pacific (Veron, 2000). Another species similar to $H$. microconos, $H$. excesa, is known from the Central Indo-Pacific. It is characterized by submassive, encrusting or subarborescent colony shape. Studied material and Ellis and Solander's (1786) Madrepora exesa are both charaterized by massive colony shapes characteristic for $H$. microconos. Thus the studied material is more similar to $H$. microconos.

Genus LEPTORIA Milne Edwards and Haime, 1848

Type species. Madrepora phrygia Ellis and Solander, 1786 (type by original designation).

Diagnosis. Merulinidae, which are colonial, with intracalicular budding. Corallites monomorphic and uniserial. Walls fused. Calice width small $(<4 \mathrm{~mm})$, with low relief $(<3 \mathrm{~mm})$. Costosepta confluent. Septa in < three cycles (<24 septa). Free septa present and irregular. Septa spaced six to 11 septa per $5 \mathrm{~mm}$. Costosepta equal in relative thickness. Columellae lamellar or spongy trabecular ( $>$ three threads), < 1/4 of calice width, and continuous amongst adjacent corallites. Paliform (uniaxial) lobes absent. Epitheca well-developed and endotheca low-moderate (tabular) (Huang et al., 2014).

Occurrence and distribution. Paleocene recent, Indo-Pacific. Oldest record in the Central Indo-Pacific, Eocene, Papua New Guinea (Gregory and Trench, 1916).

Leptoria sp. phrygia (Ellis and Solander, 1786)

Figure 8.4-5

1786 Madrepora phrygia Ellis and Solander, p. 162, pl. 48 fig. 2.

1816 Maeandrina phrygia (Ellis and Solander); Lamarck, p. 485, fig 2.

1846 Maeandrina phrygia (Ellis and Solander); Dana, p. 260 , pl. 14 figs. $8 a-8 b$.

1846 Maeandrina gracilis (Ellis and Solander); Dana, p. 261 , pl. 14 figs $6 a-8 b$. 
1846 Maeandrina tenuis (Ellis and Solander); Dana, p. 262, pl. 12 figs. $7 a-7 d$.

1977 Leptoria phrygia (Ellis and Solander); Veron et al., p. 115 , figs. $223-226$

2000 Leptoria phrygia (Ellis and Solander); Veron, p. 204 (vol. 3).

Type locality. Pacific Ocean (Ellis and Solander, 1786).

Material and occurrence. Butong Limestone Formation: QMF58243; Melinau Limestone: QMF58234, QMF58235, QMF58236, QMF58237, QMF58238, QMF58239, QMF58240; Subis Limestone: QMF58294, QMF58295. Chattian to Aquitanian. Argao, Cebu, Philippines (BLF4); Gunung Mulu, Sarawak, Malaysia (ML); Niah, Sarawak, Malaysia (SL1 and SL2).

Description. Colonies massive to encrusting. Corallites monomorphic and uniserial. Walls fused. Calice width $3.35-4.17 \mathrm{~mm}$, with low relief $(<3$ $\mathrm{mm}$ ). Costosepta confluent. Free septa present and irregular. Septa spaced six to 11 septa per 5 $\mathrm{mm}$. Costosepta equal in relative thickness. Columellae lamellar, $<1 / 4$ of calice width, and continuous amongst adjacent corallites. Paliform (uniaxial) lobes absent.

Remarks. Studied material, with exception of QMF58243, is preserved in dense limestone matrix, has no relief preserved and taxonomic characters are only visible from the cross-section cuts. Studied material resembles Leptoria phrygia and $L$. hayae in colony shape, growth form, valley size and appearance, and especially columella structure. Leptoria hayae, known from the middle to late Miocene of Fiji (Bromfield, 2013), is characterized by the deep $\mathrm{V}$ profile of the valleys not observed in the studied material (QMF58243). Thus, studied material is assigned to $L$. phrygia. Prior to description of this material $L$. phrygia has been known in the Central Indo-Pacific since Late Miocene (Umbgrove, 1945, 1946a; Veron and Kelly, 1998). This species is uncommon yet widely distributed throughout the modern Indo-Pacific (Veron, 2000).

Genus PARAMONTASTRAEA Huang and Budd, 2014

Type species. Plesiastrea salebrosa Nemenzo, 1959 (type by original designation).

Diagnosis. Merulinidae, which are colonial, with mostly extracalicular budding. Corallites monomorphic and discrete (one to three centers). Coenosteum may be spinose, moderate amount (< corallite diameter). Walls fused in some. Calice width medium $(4-15 \mathrm{~mm}$ ), with mostly low relief (< $3 \mathrm{~mm}$ ). Costosepta not confluent. Septa in three cycles ( 24 - 36 septa); fourth cycle may be present. Free septa regular. Septa spaced $>11$ septa per $5 \mathrm{~mm}$. Costosepta unequal in relative thickness. Columellae trabecular and spongy ( $>$ three threads), < 1/4 of calice width, and discontinuous amongst adjacent corallites. Paliform (uniaxial) lobes well-developed. Epitheca well-developed and endotheca low-moderate (tabular) (Huang et al., 2014).

Occurrence and distribution. Recent, IndoPacific. Fossil record unknown.

\section{Paramontastraea sp. A \\ Figure 8.6}

Material and occurrence. Melinau Limestone: QMF58500, QMF58501, QMF58502. Aquitanian. Gunung Mulu, Sarawak, Malaysia (ML).

Description. Colonies massive, with extracalicular budding. Corallites monomorphic and discrete (monocentric). Coenosteum may be spinose, moderate amount (< corallite diameter). Calice width $4.15-7.44 \mathrm{~mm}$. Costosepta not confluent. Septa in $\geq$ four cycles ( $\geq 48$ septa). Free septa regular. Septa spaced $>11$ septa per $5 \mathrm{~mm}$. Costosepta unequal in relative thickness. Columellae trabecular and spongy ( $>$ three threads), $<1 / 4$ of calice width.

Remarks. Studied material shows no preservation of the colony relief. However, growth form, corallite and septal arrangements are well visible in the cross-section (cut parallel to the surface of the colony) and correspond with genus Paramontastraea. Studied material is potentially the oldest known fossil record of this genus in the Central Indo-Pacific. However, because of the recent changes in the genera nomenclature within the family Merulinidae (Huang et al., 2014), this cannot be confirmed without detailed revision of nomenclature of known merulinids from the region.

\section{Genus PLATYGYRA Ehrenberg, 1834}

Type species. Platygyra labyrinthica Ehrenberg, 1834 (type by subsequent designation).

Diagnosis. Merulinidae, which are colonial, with intracalicular budding. Corallites monomorphic and mostly uniserial, but may also be discrete (one to three centers). Walls fused. Calice width medium $(4-15 \mathrm{~mm})$, with medium relief $(3-6 \mathrm{~mm})$. Costosepta confluent. Septa in < three cycles $(<24$ septa). Free septa present but irregular. Septa spaced six to 11 septa per $5 \mathrm{~mm}$. Costosepta equal in relative thickness. Columellae trabecular and spongy ( $>$ three threads), $<1 / 4$ of calice width, and continuous amongst adjacent corallites. Paliform (uniaxial) lobes absent. Epitheca well-developed 
and endotheca low-moderate (tabular) (Huang et al., 2014).

Occurrence and distribution. Paleocene recent, worldwide in tropical and sub-tropical regions. Oldest record in the Central Indo-Pacific, Eocene, Marshall Islands (Wells, 1964).

Platygyra cf. lamellina (Ehrenberg, 1834)

Figure 9.1-2

1834 Maeandra lamellina Ehrenberg, p. 323.

1925 Oulophyllia angusta Gerth, p. 28, pl. 5, fig. 7.

1931 Oulophyllia angusta Gerth, p. 133.

1977 Platygyra lamellina (Ehrenberg); Veron et al., p. 103-105, fig. 199.

2000 Platygyra lamellina (Ehrenberg); Veron, p. 192 (vol. 3).

2012 Platygyra lamellina (Ehrenberg); McMonagle, $p$. 226, figs.159-160.

2013 Platygyra lamellina (Ehrenberg); Bromfield, p. 40, pl. 23, fig. 7.

Type locality. Red Sea (Ehrenberg, 1834).

Material and occurrence. Butong Limestone Formation: QMF58242, Calagasan Formation: QMF58244, QMF58245, QMF58246, QMF58247, QMF58248, QMF58250, QMF58251, QMF58252, QMF58253, QMF58254, QMF58255, QMF58256, QMF58257, QMF58258, QMF58259, QMF58260, QMF58261, QMF58262, QMF58263, QMF58264, QMF58265, QMF58266, QMF58267, QMF58268, QMF58269; Trankalan/Binaguiohan Limestone: QMF58270, QMF58271. Subis Limestone: QMF58241. Chattian to Aquitanian. Argao, Cebu, Philippines (BLF4, CF6, and CF7); Candoni, Negros, Philippines (TBL); Niah, Sarawak, Malaysia (SL1).

Description. Colonies encrusting to massive. Corallites monomorphic and mostly uniserial. Walls fused ( $3 \mathrm{~mm}$ in thickness). Calice width $5.55-$ $9.09 \mathrm{~mm}$, with medium relief $(3-6 \mathrm{~mm})$. Costosepta confluent. Free septa present and irregular. Septa spaced six to 11 septa per $5 \mathrm{~mm}$. Costosepta equal in relative thickness. Columellae trabecular and spongy, < 1/4 of calice width, and continuous amongst adjacent corallites. Paliform (uniaxial) lobes absent.

Remarks. Preservation of the studied material varies: most samples have either septal arrangement or colony relief preserved. Rare samples (e.g., QMF58269) have both preserved and therefore, despite the differences in the preservation, all studied material is assigned to Platygyra cf. lamellina. Studied material is similar in colony shape, valleys arrangement, and corallite appearance and size to P. lamellina (Ehrenberg, 1834; Gerth, 1925; Gerth, 1931; Veron et al. 1977; Veron, 2000). Its thick walls and rounded septa distinguish it from a similar species Platygyra daedalea also known from the Central Indo-Pacific fossil record but which has bifurcate walls and uneven septa (McMonagle, 2012; Umbgrove,1946). In the fossil record, $P$. lamellina is known from the Oligocene of Sabah, Malaysia (McMonagle, 2012). Thus, herein studied material are the oldest known fossil record from the Central Indo-Pacific. Otherwise this species is known in the Miocene and Pliocene of Indonesia (Gerth, 1925; Gerth, 1932; Bromfield, 2013). Platygyra lamellina is uncommon yet widely distributed throughout modern Indo-Pacific reef environments (Veron, 2000).

\section{Genus TRACHYPHYLLIA Milne-Edwards and Haime, 1848}

Type species. Manicina amarantum Dana, 1846 (type by original designation).

Diagnosis. Merulinidae, which are colonial and free-living, with intracalicular budding. Corallites monomorphic and uniserial. Phaceloid (flabellomeandroid). Calice width large $(>15 \mathrm{~mm})$, with high relief $(>6 \mathrm{~mm})$. Septa in $\geq$ four cycles $(\geq 48$ septa). Free septa present and irregular. Septa spaced < six septa per $5 \mathrm{~mm}$. Costosepta unequal in relative thickness. Columellae trabecular and spongy ( $>$ three threads), $<1 / 4$ of calice width, and continuous amongst adjacent corallites. Septal (multiaxial) lobes well-developed. Epitheca welldeveloped and endotheca low-moderate (tabular) (Huang et al., 2014).

Occurrence and distribution. Paleocene recent, worldwide in tropical and sub-tropical regions. Oldest record in the Central Indo-Pacific, late Eocene, Indonesia (Wilson and Rosen, 1998).

Trachyphyllia cf. constricta (Brüggemann, 1877)

Figure 9.3-5

1877 Antillophyllia constricta Brüggeman, p. 309.

2007 Antillophyllia constricta Brüggeman; Leloux and Renema, p. 23, pl. 26, figs. 9-10.

1921b Antillia infundibuliformis Gerth, p. 408, pl. 55 fig.10.

2014 Trachyphyllia constricta (Brüggeman); Huang et al., p. 340.

Type locality and horizon. Syntypes from the Pliocene: Sondé Member, Sondé, Java, Indonesia (Leloux and Renema, 2007).

Material and occurrence. Calagasan Formation: QMF58472, QMF58473, QMF58474, QMF58475, QMF58476. Chattian. Argao, Cebu, Philippines (CF7).

Description. Coralla colonial and free-living, with intracalicular budding. Corallites monomorphic and 


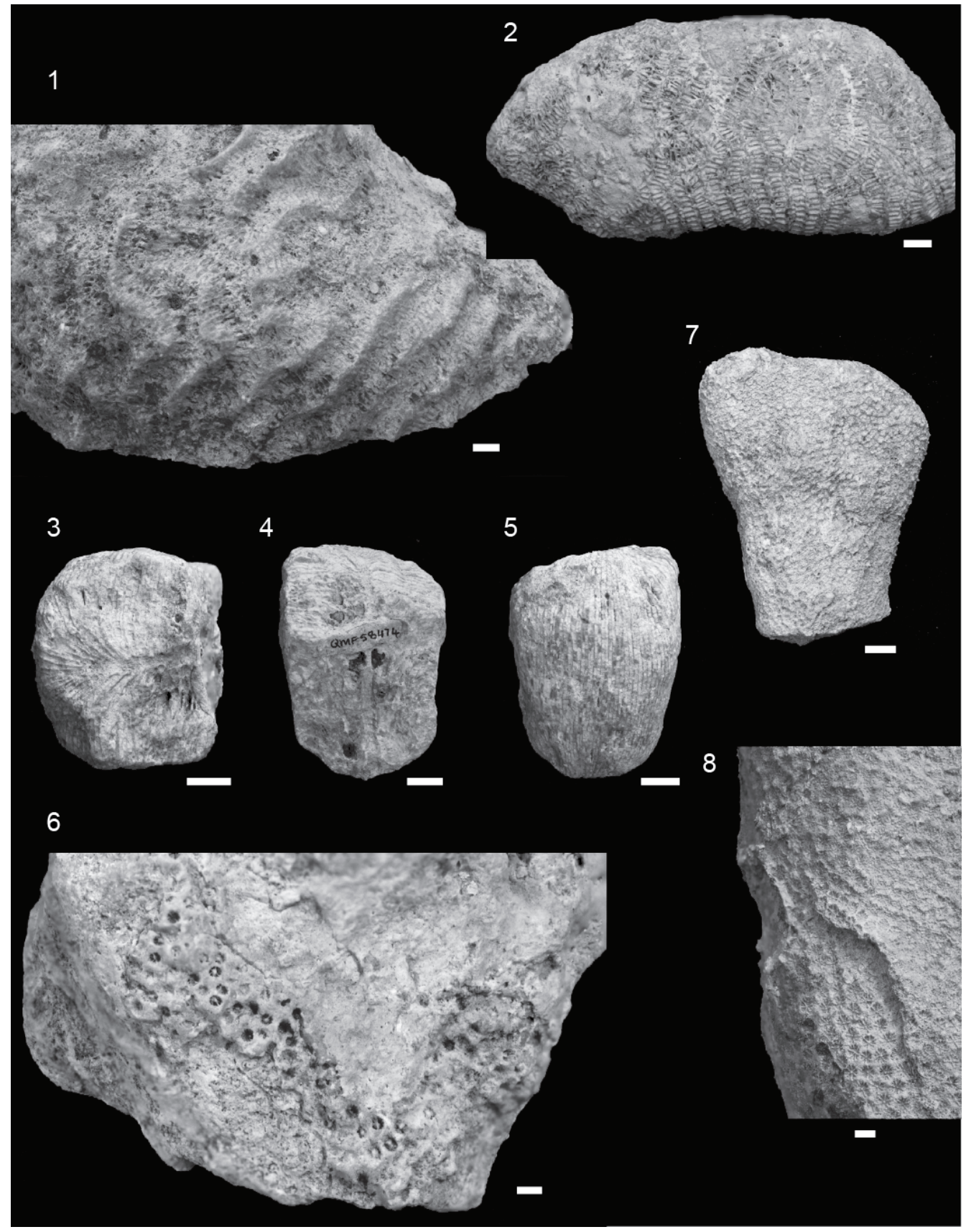

FIGURE 9. 1-2) Platygyra cf. lamellina, encrusting to massive colony with uniserial corallites. Examples here show variation in preservation: QMF58269, Calagasan Formation (late Oligocene - middle Chattian), Cebu. Specimen has both septal arrangement or colony relief preserved (1); QMF58256, Calagasan Formation (late Oligocene - middle Chattian), Cebu. Specimen has only septal arrangement preserved (2). 3-5) Trachyphyllia cf. constricta, phaceloid (flabello-meandroid) corallum with large corallites (> $15 \mathrm{~mm}$ ): QMF58474, Calagasan Formation (late Oligocene middle Chattian), Cebu. Top view on the corallum showing septal arrangement and columella (3); QMF58474, Calagasan Formation (late Oligocene - middle Chattian), Cebu. Longitudinal view through the corallum (4); QMF58474, Calagasan Formation (late Oligocene - middle Chattian), Cebu. Lateral view on the corallum showing prominent costa (5). 6) Stylophora spp., QMF58346, Calagasan Formation (late Oligocene - middle Chattian), Cebu. Branching colony with small corallites and characteristic styliform columella. Branches lithified together and surrounded by grainstone matrix. 7) Stylophora cf. pistillata, QMF58361, Calagasan Formation (late Oligocene - middle Chattian), Cebu. Fragment of flat colony branch with blunt tip. 8) Stylophora cf. pistillata, QMF58361, Calagasan Formation (late Oligocene - middle Chattian), Cebu. Monocentric and round corallites with two septal cycles and styliform columella. Scale bars equal $2 \mathrm{~mm}(6,8) ; 5 \mathrm{~mm}(1,2,7) ; 10 \mathrm{~mm}(3,4,5)$. 
uniserial. Phaceloid (flabello-meandroid). Calice width $31.51-47.51 \mathrm{~mm}$, with high relief $(56.76-$ $75.48 \mathrm{~mm}$ in height). Septa in $\geq$ four cycles ( $\geq 48$ septa). Free septa present and irregular. Septa spaced < six septa per $5 \mathrm{~mm}$. Costosepta unequal in relative thickness. Columellae trabecular and spongy, < 1/4 of calice width, and continuous amongst adjacent corallites.

Remarks. Studied material resembles Antillophyllia constricta Brueggemann, 1877 in its coneshapped corallum with pointed base, oval corallum outine, corallite size and septal arrangement. Antillophyllia constricta has been reported from six localities in Indonesia (Gerth, 1923; Umbgrove, $1938,1945,1946 b, 1950)$. Another species known from the fossil record of the region is Antillia infundibuliformis Gerth, 1921b. However, A. infundibuliformis has very pronounced flabello-meandroid corallum outline. Type species of genus Antillophyllia is Antillia lonsdaleia Duncan, 1864, which is classified as nomen dubium (WoRMS, 2016). Although the genus Antillia is a valid genus, all of its extant species belong to either genus Trachyphyllia or Cynarina. Moreover, genus Antillophyllia has been synonymized with genus Trachyphyllia (Hoeksema and Cairns, 2014). Despite challenges in the nomenclature, studied material has been assigned to genus Trachyphyllia as defined by Huang et al. (2014).

Family POCILLOPORIDAE Gray, 1842

Diagnosis. Colonial, generally ramose, with extracalicular budding. Corallites monomorphic and discrete (monocentric). Coenosteum solid or vesicular, moderate (< corallite diameter) to extensive amount ( $>$ corallite diameter). Septa rarely more than two cycles, reduced to narrow laminae, striae, or spines. Columella styliform and vertically discontinuous or poorly developed (Veron and Pichon, 1976; Wallace et al., 2009).

Genus STYLOPHORA Schweigger, 1820

Type species. Stylophora pistillata Esper, 1797 (type by original designation).

Diagnosis. Pocilloporidae, which are submassive to branching. Branches short, with blunt tips, seldom fused. Corallites monomorphic and discrete (monocentric). Coenosteum solid or vesicular, usually moderate (< corallite diameter). Septa are in two cycles, first cycle connected to columella. Columella styliform.(Veron and Pichon, 1976).

Occurrence and distribution. Cretaceous recent, worldwide in tropical and sub-tropical regions. Oldest record in the Central Indo-Pacific,
Eocene, Marshall Islands (Wells, 1964) and Papua New Guinea (Gregory and Trench, 1916).

\section{Stylophora spp.}

Figure 9.6

Material and occurrence. Butong Limestone Formation: QMF58339, QMF58340, QMF58341, QMF58342, QMF58343, QMF58344, QMF58345; Calagasan Formation: QMF58346; Melinau Limestone: QMF58347. Chattian to Aquitanian. Agaro, Cebu, Philippines (BLF4 and CF7); Gunung Mulu, Sarawak, Malaysia (ML).

Remarks. Studied material comprises both loose branches (e.g., QMF58344) and branches lithified together and surrounded by grainstone matrix (e.g., QMF58346) which prevents description of the colony shape, an important taxonomic feature for species distinction. Branches are mostly circular in cross-section (thicker branches elliptical) with blunt tips and $8.24-20.51 \mathrm{~mm}$ in diameter. Branch appearance, corallite size $(0.75-1.2 \mathrm{~mm})$ and arrangement of studied material resembles extant Stylophora subseriata, which is widely distributed throughout the modern Indo-Pacific (Veron, 2000); however, it is not known from the fossil record. Fossil species similar to $S$. subseriata is $S$. sokkohensis, know from Miocene of Indonesia (Gerth, 1923; Osberger, 1955) and Marshall Islands (Wells, 1964). Stylophora sokkohensis, however, has corallites that are larger and closer together than observed in the studied material. Other similar species known from the Central Indo-Pacific fossil record are Stylophora coalescens (Gerth, 1923; Bromfield, 2013) and Stylophora pocilloporoides (Umbgrove, 1950; Bromfield, 2013), both of which have raised walls or hoods. Due to abrasion of the studied material these features are not preserved. Thus, identification beyond the genus level is not possible. Sample QMF58347 is on the same limestone block with Fungia spp. (QMF58146).

\section{Stylophora cf. pistillata Esper, 1797}

Figure 9.7-8

1797 Madrepora pistillaris Esper, p. 73, pl. 60 fig. 1-2.

1854 Stylophora mordax (Dana); Wells, p. 411, pl. 96, fig. 5 .

1879 Stylophora palmata de Blainville, Klunzinger, p. 63, pl. 7, fig. 6, pl. 8, fig. 11.

1879 Stylophora prostrata Klunzinger, p. 62, pl. 7, fig. 8, pl. 8, fig. 7.

1898 Stylophora septata Gardiner, p. 996, pl. 62, fig.1.

1877 Stylophora sinaitica Brüggemann, p. 396, pl. 7, fig. 3 . 
1879 Stylophora pistillata (Esper); Klunzinger, p. 62, pl. 7, fig. 3, pl. 8, fig. 2.

1967 Stylophora pistillata (Esper); Scheer, p. 422.

1983 Stylophora pistillata (Esper); Scheer and Pillai, p. 22, pl. 2, figs. 3-5.

1976 Stylophora pistillata (Esper); Veron and Pichon, p. 66-70, figs 133-134.

2000 Stylophora pistillata (Esper); Veron, p. 58 (vol. 2).

2012 Stylophora pistillata (Esper); McMonagle, p. 247, figs, 179-181.

2013 Stylophora pistillata (Esper); Bromfiled, p. 14, pl. 6 , fig. 3.

Type locality. Red Sea (Scheer and Pillai, 1983).

Material and occurrence. Butong Limestone: QMF58348, QMF58349, QMF58350, QMF58351, QMF58352, QMF58353, QMF58354, QMF58355, QMF58356, QMF58357, QMF58358, QMF58359, QMF58360; Calagasan Formation: QMF58361, QMF58362, QMF58363, QMF58364. Chattian. Agaro, Cebu, Philippines (BLF2, BLF4, CF1 and CF4).

Description. Colonies branching, branches 12.90 $-23.23 \mathrm{~mm}$ in diameter. Branches short and flat, with blunt tips, seldom fused. Corallites monomorphic and discrete (monocentric). Coenosteum vesicular, uneven amount (spacing between corallites $<0.5 \mathrm{~mm}$ ). Calice width $0.72-1.39 \mathrm{~mm}$. Septa in two cycles, first cycle connected to columella. Columella styliform.

Remarks. Studied material comprises both loose branches (e.g., QMF58361) and branches lithified together in a grainstone matrix (e.g., QMF58355). Branch appearance, corallite size and arrangement, and coenosteum texture of studied material resembles Stylophora pistillata (Esper, 1797; Brüggemann, 1877; Klunzinger, 1879; Gardiner, 1898; Veron and Pichon, 1976). As a response to environmental conditions $S$. pistillata shows many variations in colony shape and appearance which is reflected in the long synonymy list (Veron and Pichon, 1976). In the fossil record, this species is known from Oligocene of Sabah, Malaysia (McMonagle, 2012). Thus, herein studied material together with the $S$. pistillata records from Sabah are the oldest known fossil record from the Central Indo-Pacific. This species is a common and wellknown species in the Miocene of the Central IndoPacific (Gerth, 1923; Umbgrove, 1929, 1945; Osberger, 1954b; McMonagle, 2012; Bromfield, 2013). Stylophora pistillata is widely distributed throughout the modern Indo-Pacific and Red Sea (Wells, 1954; Scheer, 1967; Scheer and Pillai, 1983; Veron, 2000). It can be a dominant species in some exposed reef environments (Veron and Pichon, 1976).

Family PORITIDAE Gray, 1842

Diagnosis. Massive, laminar or ramose colonies; corallites vary in size but usually small and mostly compacted closely without coenosteum, with one or two synapticular rings. Walls and septa are porous. Septa usually 12 to 24 . Septa formed by three to eight nearly vertical trabeculae, and innermost trabeculae of certain septa differentiated as pali (Vaughan and Wells, 1943; Veron, 2000; Wallace et al., 2009).

\section{Genus DICTYARAEA Reuss, 1867}

Type species. Dictyaraea micrantha Reuss, 1867 (type by original designation).

Diagnosis. Poritidae, which are branching (slender branches), with extracalicular budding. Corallites small, compacted closely without coenosteum. Walls and septa are porous. Septa usually 12 to 24 . Septa composed of vertical trabeculae. Corallite arrangement variable, sometimes in rows (Bromfield, 2013).

Occurrence and distribution. Cretaceous recent, Indo-Pacific and Tethys (and Cretaceous records from the USA). Oldest record in the Central Indo-Pacific, late Eocene, Indonesia (Gerth, 1933).

Dictyaraea cf. anomala Reuss, 1867 Figure 10.1

1880 Dictyaraea anomala Reuss; Martin, p. 150, pl. 25, fig. 18-19.

1929 Dictyaraea anomala Reuss; Umbgrove, p. 68, pl. 1, figs. 5, 9-10.

Type locality and horizon. Duangerreg, Java, Indonesia (Reuss, 1867).

Material and occurrence. Butong Limestone Formation: QMF58365. Chattian. Argao, Cebu, Philippines (BLF4).

Description. Colony branching. Branches width $10.11-16.57 \mathrm{~mm}$. Branch elliptical in cross-section. Corallites discrete (monocentric). Corallites elliptical to polygonal, $2.29-3.65 \mathrm{~mm}$ in diameter, compacted closely without coenosteum.

Remarks. Studied material, with its polygonal corallites and their size, resembles fossil Dictyaraea anomala. This species is common and well-known from the Miocene of Indonesia (Reuss, 1867; Felix, 1921; Gerth, 1923; Umbgrove, 1945; Santodomingo et al., 2016), but the studied material is the oldest fossil record. No septa are preserved, but this is not uncommon for Dictyaraea as visible on material described by Martin, 1880 and Umbgrove, 1929. 
Dictyaraea cf. micrantha Reuss, 1867

Figure 10.2-3

1880 Dictyaraea cf. micrantha Reuss; Martin, p. 150, pl. 25 fig. 16-17.

1921 Dictyaraea cf. micrantha Reuss; Gerth, p. 434.

1929 Dictyaraea cf. micrantha Reuss; Umbgrove, $p$. 68-69, pl. 1 fig. 4.

2012 Dictyaraea cf. micrantha Reuss; McMonagle, $p$. 126, figs. 63-64.

2013 Dictyaraea cf. micrantha Reuss; Bromfield, p. 16.

Type locality. Duangerreg, Java, Indonesia (Reuss, 1867).

Material and occurrence. Butong Limestone Formation: QMF58366, QMF58367, QMF58368, QMF58369, QMF58370; Calagasan Formation: QMF58371. Chattian. Argao, Cebu, Philippines (BLF4 and CF6).

Description. Colonies branching. Branches width $5.3-8.49 \mathrm{~mm}$. Branches flattened, mostly elliptical in cross-section and sometimes fused. Corallites discrete (monocentric). Corallites round to elliptical in outline, $0.85-1.39 \mathrm{~mm}$ in diameter, compacted closely without coenosteum.

Remarks. Studied material, with its round/elliptical corallites and their size, resembles fossil $D$. micrantha (Martin, 1880; Gerth, 1921; Umbgrove, 1929). In the fossil record, this species is known from Oligocene of Sabah, Malaysia (McMonagle, 2012). Thus, herein studied material together with the Dictyaraea micrantha records from Sabah are the oldest known fossil record from the Central Indo-Pacific. This species is common and wellknown in the Miocene fossil record of Indonesia and Malaysia (Martin, 1879; Gerth, 1923; Umbgrove, 1929; Osberger, 1954b; McMonagle, 2012; Santodomingo et al., 2016). No septa are preserved, but this is not uncommon for Dictyaraea as it has rudimentary septa (Umbgrove, 1929; McMonagle, 2012; Bromfield, 2013).

Genus GONIOPORA de Blainville, 1830

Type species. Goniopora pedunculata Quoy and Gaimard, 1833 (type by original designation).

Diagnosis. Poritidae, which are massive, columnar or ramose, rarely encrusting colonies. Corallites monomorphic, discrete (monocentric), may be round or polygonal in outline. Walls thick but porous. Calice diameter $1-10 \mathrm{~mm}$. Septa generally in three cycles, formed by four to eight trabeculae. Septa may be fused, but not as consistently as in Porites. Pali and columella may develop. Columellae are composed of anastomosed septal dentations or arranged synapticula and fused inner ends of septa (Bernard, 1903; Vaughan and Wells, 1943; Veron and Pichon, 1982).

Occurrence and distribution. Paleocene recent, worldwide in tropical and sub-tropical regions. Oldest record in the Central Indo-Pacific, late Eocene, Indonesia (Gerth, 1933).

Goniopora cf. tenuidens (Quelch, 1886) Figure 10.4

1886 Rhodaraea tenuidens Quelch, p. 188, pl. 8, figs. $7-7 \mathrm{~b}$.

1946 Goniopora tenuidens (Quelch); Umbgrove, p. 540 , pl. 82, fig. 4.

1982 Goniopora tenuidens (Quelch); Veron and Pichon, p. 83, figs. 156-161.

2000 Goniopora tenuidens (Quelch); Veron, p. 364 (vol. 3).

2007 Goniopora tenuidens (Quelch); Leloux and Renema, p. 36, pl. 52, figs. 5-6.

2013 Goniopora tenuidens (Quelch); Bromfield, p. 19.

Type locality. Santa Cruz Major Isalnd, off Samboangan, Philippines (Quelch, 1886).

Material and occurrence. Calagasan Formation: QMF58372. Chattian. Argao, Cebu, Philippines (CF6).

Description. Colony massive. Corallites monomorphic, discrete (monocentric) and mostly round in outline. Calice diameter $3.87-7.80 \mathrm{~mm}$. Septa in three cycles. Some septa fused. Columellae well-developed, $<1 / 4$ of calice width. Pali welldeveloped.

Remarks. Studied material resembles Goniopora tenuidens in colony shape, corallite appearance and prominent pali. Corallite size of the studied material seems to be larger than corallite size in coral material described by other authors where average corallite size is around $3 \mathrm{~mm}$ (Quelch, 1886; Veron and Pichon, 1982; Veron, 2000; Bromfield, 2013). However, fossil material from Java studied by Umbgrove, 1946, and illustrated in Leloux and Renema, 2007, shows the same range of corallite sizes as the specimen from the Philippines. Goniopora tenuidens is known in the Central Indo-Pacific fossil record since the late Miocene (Bromfield, 2013), making the studied material the oldest known fossil record of this species. This species is common and widely distributed throughout the modern Indo-Pacific (Veron, 2000).

Goniopora cf. planulata (Ehrenberg, 1834) Figure 10.5-6

1834 Astraea planulata Ehrenberg, p. 319.

1879 Goniopora planulata (Ehrenberg); Kluzinger, p. 45, pl. 8, fig. 23; pl. 5, fig. 24. 


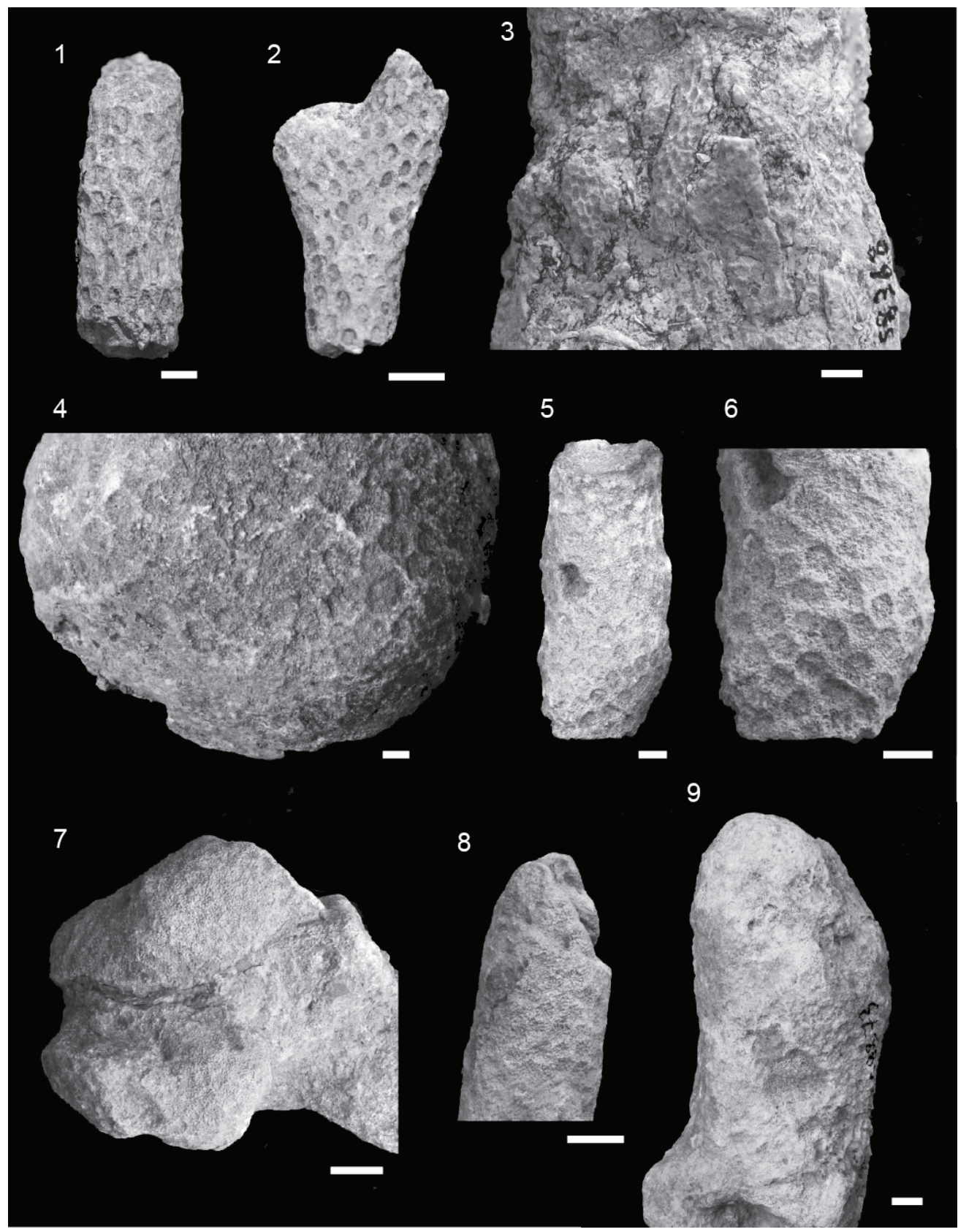

FIGURE 10. 1) Dictyaraea cf. anomala, QMF58365, Butong Formation (late Oligocene - late Chattian), Cebu. Branch fragment (elliptical in cross-section) with monocentric corallites, elliptical to polygonal in outline. 2) Dictyaraea cf. micrantha, QMF58369, Butong Formation (late Oligocene - late Chattian), Cebu. Branch fragment (flattened) with monocentric corallites, round to elliptical in outline. 3) Dictyaraea cf. micrantha, QMF58368, Butong Formation (late Oligocene - late Chattian), Cebu. Branch fragments lithified together and surrounded by grainstone matrix.4) Goniopora cf. tenuidens, QMF58372, Calagasan Formation (late Oligocene - middle Chattian), Cebu. Massive colony with monocentric and mostly round corallites with weak to moderate paliform lobes. Overall preservation poor. 5-6) Goniopora cf. planulata, branching colony with monocentric corallites, mostly round or irregular in outline: QMF58381, Butong Formation (late Oligocene - late Chattian), Cebu. Branch fragment (5); QMF58381, Butong Formation (late Oligocene - late Chattian), Cebu (6). 7-8) Goniopora cf. palmensis, Branching colony with branches mostly circular in cross-section. Corallites monomorphic, monocentric, mostly round in outline: QMF58390, Butong Formation (late Oligocene - late Chattian), Cebu (7); QMF58396, Calagasan Formation (late Oligocene - middle Chattian), Cebu. Close up view of the corallites (8). 9) Porites sp. A, QMF58365, Trankalan/Binaguiohan (early Miocene - Aquitanian), Negros. Columnar colony, poorly preserved but "spongy" skeleton structure and corallite outline visible. Scale bars equal $5 \mathrm{~mm}$. 
1923 Goniopora planulata (Ehrenberg); Gerth, p. 118, pl. 9, fig. 6.

1939 Goniopora planulata (Ehrenberg); Umbgrove, p. 65 , fig. 8.

1986 Goniopora planulata (Ehrenberg); Pillai, p. 155, pl. 8, fig. 1.

2000 Goniopora planulata (Ehrenberg); Veron, p. 368 (vol. 3).

2007 Goniopora planulata (Ehrenberg); Leloux and Renema, p. 36, pl. 62, figs. 2-4.

2013 Goniopora planulata (Ehrenberg); Bromfield, p. 18.

Type locality. Red Sea (Ehrenberg, 1834).

Material and occurrence. Butong Limestone Formation: QMF58376, QMF58377, QMF58378, QMF58379, QMF58380, QMF58381, QMF58382, QMF58383; Calagasan Formation: QMF58384, QMF58385, QMF58386, QMF58387, QMF58388. Chattian. Argao, Cebu, Philippines (BLF1, BLF2, BLF4, CF6, and CF7).

Description. Colonies branching to columnar. Branches width $14.09-23.88 \mathrm{~mm}$. Corallites monomorphic, discrete (monocentric), irregular in outline but mostly round. Calice diameter 2.73 $4.14 \mathrm{~mm}$. Septa in three cycles. Some septa fused. Pali and columella developed. Columellae $<1 / 4$ of calice width.

Remarks. Studied material belongs to Goniopora Group 5: Branching to columnar species with medium (3 - $5 \mathrm{~mm}$ diameter) corallites (Veron, 2000) and resembles G. planulata with its corallite size and appearance (Ehrenberg, 1834; Kluzinger, 1879; Pillai, 1986). Goniopora planulata is known in the Central Indo-Pacific fossil record since the Eocene (Gerth, 1933) and has been well known from the Miocene fossil record of Indonesia (Gerth, 1923; Umbgrove, 1939; Bromfield, 2013). This species is uncommon yet widely distributed throughout the modern Indo-Pacific (Veron, 2000). In comparison to G. cf. palmensis, studied material has thicker branches, generally larger corallites and less prominent paliform lobes (Table 6).
Goniopora cf. palmensis Veron and Pichon, 1982 Figure 10.7-8

1982 Goniopora palmensis Veron and Pichon, p. 99, figs. 191-198.

2000 Goniopora palmensis Veron and Pichon; Veron, p. 347 (vol. 3)

2013 Goniopora palmensis Veron and Pichon; Bromfiled, p. 18, pl. 8, fig. 5.

Type locality. Orpheus Island, Australia (Veron and Pichon, 1982).

Material and occurrence. Butong Limestone Formation: QMF58389, QMF58390, QMF58391, QMF58392, QMF58393, QMF58394, QMF58395; Calagasan Formation: QMF58396, QMF58397. Chattian. Argao, Cebu, Philippines (BLF2, BLF4, and CF3).

Description. Colonies branching. Branch width 8.55 - $19.67 \mathrm{~mm}$. Branches mostly circular in cross-section. Corallites monomorphic, discrete (monocentric), mostly round in outline. Calice diameter $2.21-3.66 \mathrm{~mm}$. Septa in three cycles. Some septa fused. Pali and columella developed. Columellae $<1 / 4$ of calice width.

Remarks. Studied material comprises both loose branches (e.g., QMF58396) and branches lithified together surrounded by grainstone matrix (e.g., QMF58390). Despite the branches being eroded and therefore poorly preserved colony relief, the studied material resembles Goniopora palmensis with its colony shape, corallite size and appearance, and prominent paliform lobes (Veron and Pichon, 1982, Veron, 2000). Goniopora palmensis is known in the Central Indo-Pacific fossil record since the early Miocene (Bromfield, 2013), making the studied material the oldest known fossil record of this species. This species is common and widely distributed throughout the modern Indo-Pacific (Veron, 2000).

\section{Genus PORITES Link, 1807}

Type species. Porites polymorphus Link, 1807 (type by original designation).

TABLE 6. Comparison of taxonomic differences between morphospecies within genus Goniopora.

\begin{tabular}{|c|c|c|c|c|c|}
\hline Morphospecies & $\begin{array}{l}\text { Colony } \\
\text { shape }\end{array}$ & $\begin{array}{l}\text { Branch } \\
\text { diameter }\end{array}$ & $\begin{array}{l}\text { Average corallite } \\
\text { width }(\mathrm{mm})\end{array}$ & Corallite outline & Paliform lobes \\
\hline $\begin{array}{l}\text { Goniopora cf. } \\
\text { palmensis }\end{array}$ & branching & $8.55-19.67$ & $2.21-3.66$ & mostly round & prominent \\
\hline $\begin{array}{l}\text { Goniopora cf. } \\
\text { planulata }\end{array}$ & $\begin{array}{l}\text { branching to } \\
\text { columnar }\end{array}$ & $14.09-23.88$ & $2.73-4.14$ & mostly round or irregular & moderate \\
\hline $\begin{array}{l}\text { Goniopora cf. } \\
\text { tenuidens }\end{array}$ & massive & NA & $3.87-7.80$ & mostly round & weak to moderate \\
\hline
\end{tabular}


Diagnosis. Poritidae, which are massive, ramose, laminar or encrusting. Corallites small, immersed, round or polygonal in outline. Calice diameter $0.5-$ $2.2 \mathrm{~mm}$. Septa are 12 in number, composed of one to four trabeculae. The typical formula of septal arrangement in this genus, with some of its variations, is seen. Pali are present, variable development in different species, usually four to eight in number. Mural trabeculae always present. Columella trabeculae usually present with star-shaped granules. The wall is simple, but the incipient synapticulae, seen starting from the sides of septal granules, may become complete and form an inner synapticular wall (Bernard, 1903; Vaughan and Wells, 1943; Veron, 2000).

Occurrence and distribution. Paleocene recent, worldwide in tropical and sub-tropical regions. Oldest record in the Central Indo-Pacific, late Eocene, Indonesia (Gregory and Trench, 1916).

\section{Porites sp. A}

Figure 10.9

Material and occurrence. Trankalan/Binaguiohan Limestone: QMF58373. Aquitanian. Candoni, Negros, Philippines (TBL).

Description. Colony columnar. Coenosteum absent. Corallites round in outline. Calice diameter 1.4 - 1. 95 mm. Septa Porites-like. Columella trabecular.

Remarks. Studied material is poorly preserved: only colony shape and corallite outline are well-visible. Septal structure barely visible within the dense, regular mesh-like skeletal matrix but shows Porites-like characters (Humblet et al., 2014).

\section{Porites spp.}

Figure 11.1-4

Material and occurrence. Butong Limestone Formation: QMF58399, QMF58400, QMF58401, QMF58402; Calagasan Formation: QMF58403; Subis Limestone: QMF58159, QMF58404, QMF58405, QMF58406, QMF58407, QMF58408; Trankalan/Binaguiohan Limestone: QMF58398, QMF58409. Chattian to Aquitanian. Argao, Cebu, Philippines (BLF2, BLF4, and CF7); Candoni, Negros, Philippines (TBL); Niah, Sarawak, Malaysia (SL1 and SL2).

Remarks. Studied material comprised of massive colonies with corallites round to polygonal in outline. Substantial variation in preservation of studied material (Figure 11.1-2, 11.4) prevents identification beyond the genus level. However, all samples have similar colony shape, corallite size $(0.9-1.39$ $\mathrm{mm}$ ) and arrangement, two septal cycles, trabecu- lar columella and pali, therefore, are considered to be Porites spp. Generally, material from the Butong and Calagasan Formations contains whole, small ( $\sim 10 \mathrm{~cm}$ in diameter) colonies (e.g., QMF58401).

\section{Family SCLERACTINIA INCERTAE SEDIS}

Diagnosis. Due to the evidence brought by new molecular studies (Fukami et al., 2008; Budd et al., 2012) no family can be assigned to these genera. Further molecular and morphological studies will help clarify their position within the order Scleractinia.

\section{Genus ACTINASTREA d'Orbigny, 1849}

Type species. Actinastrea goldfussi d'Orbigny, 1850 (type by original designation).

Diagnosis. Colonies massive, ramose or encrusting, formed by extracalicular budding. Corallites monomorphic and discrete (monocentric). Wall present, compact, septothecal. Coenosteum limited, made of costae and single large trabeculae, coarsely granulated on surface. Corallites round in outline and very small. Septa compact. In crosssection, septa thick and globular at the external face, very thin towards the center of the calice. Symmetry of septa regular radial. Cycles of septa regular, differ by septal length. First septal cycle reaches to the center of the calice, further cycles subsequently shorter. Septa of the younger cycles occasionally attached to those of the first or second cycle. All septa of the first cycle attached to the columella. Costae very short and non-confluent. Their external part swollen and partly forms the thick granules visible on the surface of the coenosteum. Columella styliform. Pali or paliform lobes absent. Endotheca consists of thin tabulae (Löser, 2011).

Occurrence and distribution. Eocene - recent, worldwide in tropical and sub-tropical regions. Oldest record in the Central Indo-Pacific, Oligocene, Sabah, Malaysia (McMonagle, 2012).

Actinastrea cf. minutissima (Gerth, 1921)

Figure 11.5-7

1921b Astrocoenia minutissima Gerth, p. 419-420.

1923 Astrocoenia minutissima Gerth; Gerth, p. 94, pl. 7, figs. 2-4.

1925 Astrocoenia minutissima Gerth; Gerth, p. 62.

1929 Astrocoenia minutissima Gerth; Umbgrove, p. 61.

1931 Astrocoenia minutissima Gerth; Gerth, p. 138, 146, 147.

1933 Stylophora minutissima (Gerth); Gerth, p. 3839.

1946b Stylocoeniella? minutissima (Gerth); Umbgrove, p.523. 


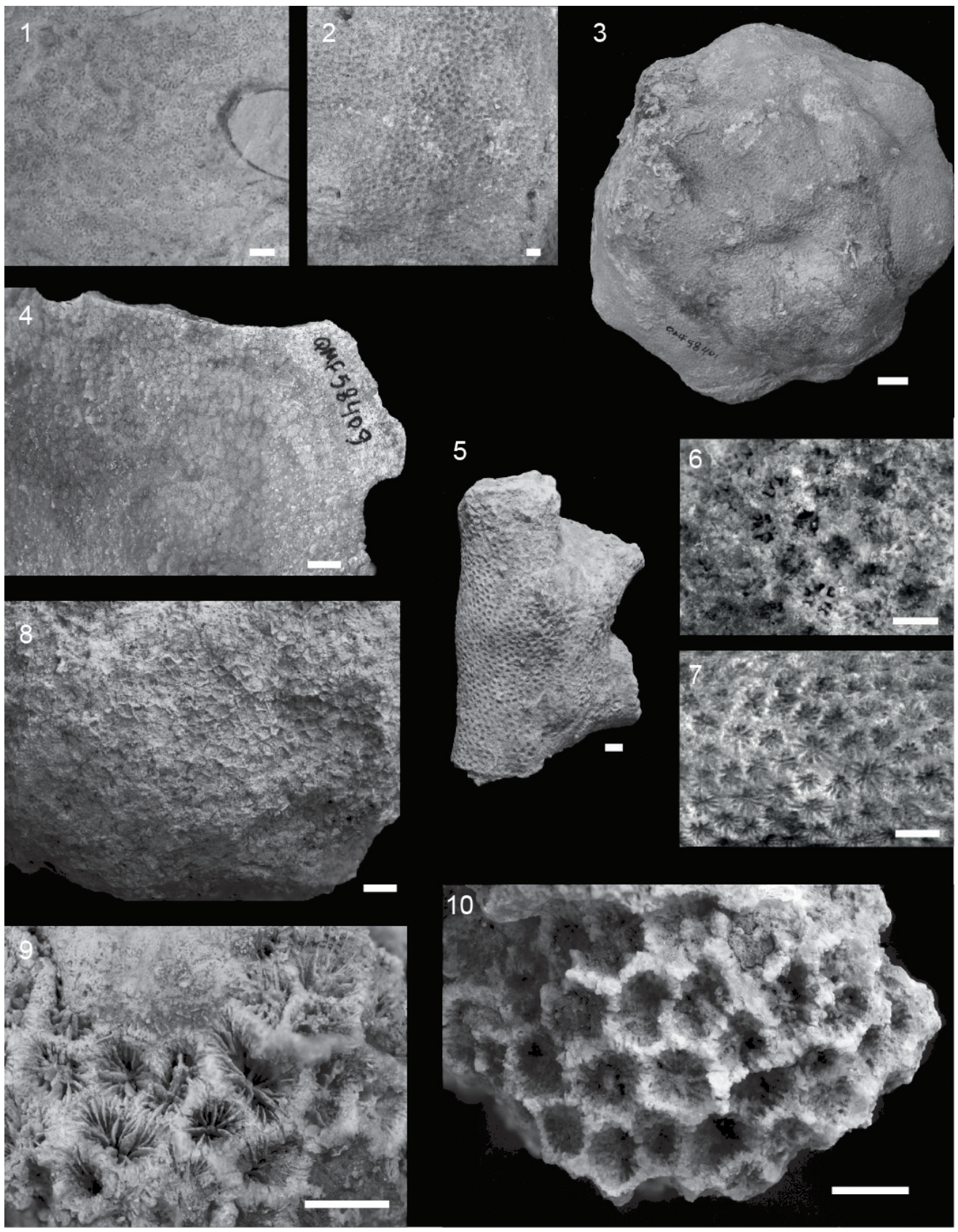

FIGURE 11. 1-4) Porites spp., Massive colonies with small, immersed, round or polygonal corallites. Examples here show variation in preservation of the morphospecies in different lithologies: QMF58405, Subis Limestone (early Miocene - Aquitanian), Sarawak. Close up view of the corallites (1); QMF58400, Butong Formation (late Oligocene - late Chattian), Cebu. Close up view of the corallites (2); QMF58401, Butong Formation (late Oligocene - late Chattian), Cebu. Small massive colony (3); QMF58409, Trankalan/Binaguiohan (early Miocene - Aquitanian), Negros. Close up view of the corallites (4). 5) Actinastrea cf. minutissima, QMF58462, Calagasan Formation (late Oligocene - middle Chattian), Cebu. Branch fragment. 6) Actinastrea cf. minutissima, QMF58425, Butong Formation (late Oligocene late Chattian), Cebu. Close up view of the corallites. Example of poor preservation. 7) Actinastrea cf. minutissima, QMF58425, Butong Formation (late Oligocene - late Chattian), Cebu. Close up view of the corallites. Example of good preservation. 8) Blastomussa cf. simplicitexta, QMF58505, Trankalan/Binaguiohan (early Miocene - Aquitanian), Negros. Massive colony with monocentric corallites and limited coenosteum. Overall preservation poor. 9) Leptastrea cf. transversa, QMF58484, Calagasan Formation (late Oligocene - middle Chattian), Cebu. Encrusting colony, with irregular relief and corallites irregular in outline. 10) Leptastrea sp. A, QMF58487, Calagasan Formation (late Oligocene - middle Chattian), Cebu. Massive colony, with corallites irregular in outline. Scale bars equal $1 \mathrm{~mm}$ $(6,7) ; 2 \mathrm{~mm}(1,2,5) ; 5 \mathrm{~mm}(4,8,9) ; 10 \mathrm{~mm}(3,10)$. 
1964 Actinastrea minutissima (Gerth); Wells, p.1103, pl. 296, figs. 1-4, pl. 300, fig. 1.

2012 Actinastrea minutissima (Gerth); McMonagle, p. 86, figs. 31-32.

Type locality and horizon. West Progo Beds near Kembang Sokkoh, Java, Indonesia (Gerth, 1921b).

Material and occurrence. Butong Limestone Formation: QMF58410, QMF58411, QMF58412, QMF58413, QMF58414, QMF58415, QMF58416, QMF58417, QMF58418, QMF58419, QMF58420, QMF58421, QMF58422, QMF58423, QMF58424, QMF58425, QMF58426, QMF58427, QMF58428, QMF58429, QMF58430, QMF58431, QMF58432, QMF58433; Calagasan Formation: QMF58434, QMF58435, QMF58436, QMF58437, QMF58438, QMF58439, QMF58440, QMF58441, QMF58442, QMF58443, QMF58444, QMF58445, QMF58446, QMF58447, QMF58448, QMF58449, QMF58450, QMF58451, QMF58452, QMF58453, QMF58454, QMF58455, QMF58456, QMF58457, QMF58458, QMF58459, QMF58460, QMF58461, QMF58462, QMF58463, QMF58464, QMF58465, QMF58466, QMF58467, QMF58468, QMF58469, QMF58470, QMF58471. Chattian. Argao, Cebu, Philippines (BLF1, BLF2, BLF4, CF1, CF2 and CF4).

Description. Colonies branching, with branches 6.45 - $37.56 \mathrm{~mm}$ in diameter. Branches flattened, mostly elliptical in cross-section and sometimes fused. Corallites monomorphic and discrete (monocentric). Wall present, compact, septothecal. Coenosteum limited, coarsely granulated on surface. Corallites round in outline, $0.44-1.11 \mathrm{~mm}$ in width. Septa in two cycles. First septal cycle reaches to the center of the calice, further cycles subsequently shorter. All septa of the first cycle attached to the columella. Costae very short and non-confluent. Columella styliform. Pali or paliform lobes absent.

Remarks. Studied material varies in preservation quality: in some branch fragments corallite relief is better preserved (QMF58425), and in others septal arrangement is preserved (QMF58425). This genus is known from Triassic of Tethys and the Protoatlantic, and the only known species from the Indo-Pacific is Actinastrea minutissima, which the examined material resembles in its colony shape, growth form, corallite size and septal arrangement. Gerth, 1921b, first described this species from the Miocene of Indonesia. Since then the species has been reported from variety of locations in Indonesia, Malaysia and Eniwetok Atoll (Gerth, 1923, 1925; Umbgrove, 1929; Gerth, 1931, 1933; Umbgrove, 1946b; Wells, 1964; McMonagle, 2012). Studied material is first report of this species from the Philippines. Genus Actinastrea has been assigned to two different families, Astrocoeniidae Koby, 1890 by Vaughan (1943) and Actinastreidae Alloiteau 1952 by Alloiteau (1952), neither of which are well defined (Löser, 2011). Moreover, in 2014 Kiessling renamed Actinastrea minutissima to Stylocoeniella minutissima in the Paleobiology Database (PBDB; paleobiodb.org). Here I use genus name Actinastrea as it is the name used by Löser (2011), which contains detailed revision and discussion of the genus.

\section{Genus BLASTOMUSSA Wells, 1968}

Type species. Bantamia merleti Wells, 1961 (type by original designation).

Diagnosis. Solitary or colonial. Colonies phaceloid and encrusting to massive, with extracalicular budding. Coenosteum costate, limited (includes double wall). Corallite wall septothecal. Septa composed of one or more fan systems each forming a lobate tooth, septal sides ornamented by fine granulations. Columella present, trabecular, pronounced and showing bilateral arrangement of fused processes reduced to few granulate papillae. Epitheca well-developed and extended until a few $\mathrm{mm}$ below the wall margin in phaceloid coralla. Endothecal dissepiments vesicular, inclined downward from the corallite wall (Benzoni et al., 2014).

Occurrence and distribution. Miocene - recent, Indo-Pacific. Oldest record in the Central IndoPacific, late Miocene, Indonesia (Santodomingo et al., 2016).

Blastomussa cf. simplicitexta (Umbgrove, 1942) Figure 11.8

1942 Goniastrea simplicitexta Umbgrove, p. 35, pl. 7, fig. 4, pl. 8, fig. 5 .

1988 Parasimplastrea simplicitexta (Umbgrove); Veron and Kelly, p. 49, figs. 16A -16D.

2013 Parasimplastrea simplicitexta (Umbgrove); Bromfield, p. 39, pl. 23 figs. 2-3.

2014 Blastomussa simplicitexta (Umbgrove). Benzoni et al., p. 358.

Type locality and horizon. Sampolakosa Formation, Waisiu, Buton Island, Indonesia (Umbgrove, 1942).

Material and occurrence. Trankalan/Binaguiohan Limestone: QMF58505. Aquitanian. Candoni, Negros, Philippines (TBL).

Description. Colony massive. Corallites monomorphic and discrete (monocentric). Coenosteum mostly limited (double wall). Corallite width 5.15 $6.78 \mathrm{~mm}$. Six to eight well-developed septa meet at the columella. Columella rudimentary. 
Remarks. Studied material poorly preserved, but colony shape, growth form, corallite size, polygonal corallite outline and septal arrangement resemble fossil Blasstomussa simplicitexta Umbgrove, 1942. This species has been assigned to different genera, most recently to genus Blasstomussa due to revison of the phylogenetic relationships within this group (Benzoni et al., 2014). Benzoni et al., 2014, also suggest synonymy with $B$. omanensis. However, this does not seem to be widely accepted. The overall simple appearence that gives the species its name has been described by all authors (Umbgrove, 1942; Veron and Kelly, 1988; Bromfield, 2013). Prior to description of this material $B$. simplicitexta has been known in the Central IndoPacific fossil record since the late Miocene (Umbgrove, 1945), making the studied material the oldest known fossil record of this species.

\section{Genus LEPTASTREA Milne Edwards and Haime,} 1849

Type species. Leptastrea roissyana Milne Edwards and Haime, 1849 (type by subsequent designation).

Diagnosis. Colonies encrusting to massive, usually flat or dome-shaped, with extracalicular budding. Coenosteum costate, limited amount (includes double wall) or fused walls. Septa with inward-projecting teeth. Costae poorly developed or absent. Columellae consist of vertical pinnules (Veron, 1986).

Occurrence and distribution. Eocene - recent, worldwide in tropical and sub-tropical regions (mostly Indo-Pacific). Oldest record in the Central Indo-Pacific, late Eocene, Indonesia (Gerth, 1933).

\section{Leptastrea cf. transversa Klunzinger, 1879} Figure 11.9

1879 Leptastrea transversa Klunzinger, p. 46, pl. 6, fig. 2.

1886 Leptastrea transversa Klunzinger; Quelch, p. 109.

2000 Leptastrea transversa Klunzinger; Veron, p. 238 (vol. 3).

2013 Leptastrea transversa Klunzinger; Bromfield, $\mathrm{p}$. 37, pl. 20, figs. 1-4.

Type locality. Red Sea (Klunzinger, 1879).

Material and occurrence. Butong Limestone Formation: QMF58477; Calagasan Formation: QMF58478, QMF58479, QMF58480, QMF58481, QMF58482, QMF58483, QMF58484, QMF58485, QMF58486. Chattian. Argao, Cebu, Philippines (BLF4, CF6 and CF7).
Description. Colonies encrusting, with irregular relief. Corallites monomorphic and discrete (monocentric). Coenosteum costate, limited amount (double wall), $\sim 1.20-1.83 \mathrm{~mm}$ in thickness. Corallites irregular in outline, $3.15-5.57 \mathrm{~mm}$ in width. Costae absent. Septa arranged in three unequal orders. Primary septa thicker near the corallite wall and reach columella. Septa plunge steeply near columella. Columella consist of few pinnules.

Remarks. Colony shape, corallite size and appearance of studied material, as well as its septal arrangement and steepness, resemble Leptastrea transversa. Klunzinger, 1879 first describes this species from the Red Sea. Quelch, 1886 uses the same species name to describe material from Tahiti despite the colony shape of Tahitian material appears to be encrusting rather than plate-like such as in the material from the Red Sea. However, specimens illustrated in Veron, 2000 show some variation in colony shape. The colony shape of the studied material most resembles the material described by Quelch, 1886 and Bromfield, 2013. In the fossil record, this species is known from Oligocene of Sabah, Malaysia (McMonagle, 2012). Thus, herein studied material together with the $L$. transversa records from Sabah are the oldest known fossil record from the Central Indo-Pacific. This species is widespread but uncommon in the Indo-Pacific today (Veron, 2000).

\section{Leptastrea sp. A \\ Figure 11.10}

Material and occurrence. Calagasan Formation: QMF58487, QMF58488, QMF58489, QMF58490. Chattian. Argao, Cebu, Philippines (CF7).

Description. Colonies massive. Corallites monomorphic and discrete (monocentric). Coenosteum costate, limited amount (double wall), $2.29-3.10$ $\mathrm{mm}$ in thickness. Corallites irregular in outline, 4.82 - $9.73 \mathrm{~mm}$ in width. Costae absent. Septa arranged in three unequal orders. Primary septa thicker near the corallite wall and reach columella. Septa plunge steeply near columella. Columella consist of few pinnules.

Remarks. Preservation of studied material varies within the colonies: only few corallites have septal structure preserved whereas most have only the walls. Corallite size of the studied material is larger than corallites of any of extant Leptastrea species. However, septal arrangement and appearance (plunging steeply near columella) are typical for the genus. In comparison to Leptastrea cf. transversa, which is encrusting, Leptastrea sp. A has massive colony shape and larger corallites. 


\section{DISCUSSION}

The new fossil collection described from Malaysia and the Philippines yielded 44 morphospecies belonging to 30 genera and nine families (excluding Incertae sedis), and $5 \mathrm{spp}$. taxa, each potentially representing multiple morphospeices. Open nomenclature has been used herein because not all species diagnostic characters have been preserved, or their preservation is too poor to be used for taxonomic purposes and creates a degree of uncertainty in species-level identifications. Material described herein is the largest collection of the Chattian-Aquitanian scleractinians known from the Central Indo-Pacific. The stratigraphic ranges of four genera (Acanthastrea, Astrea, Coelastrea, Lobophyllia) have been extended back to the Chattian. An additional eight genera (Acropora, Actinastrea, Fungia, Gardineroseris, Goniastrea, Hydnophora, Leptoseris, Pachyseris) originally described from Chattian deposits in Sabah, Malaysia (McMonagle, 2012) have now also been described in the Chattian deposits of Sarawak, Malaysia and the Philippines. Fossil records of genera Blastomussa (from late Miocene) and Paramontastraea (no fossil record) have been extended to the Aquitanian. However, the genus Paramontastraea, so far known only from the modern Indo-Pacific, is a relatively new genus (see Huang et al., 2014), which includes Indo-Pacific coral species that superficially resemble the genus Montastraea. Therefore, fossil specimens from this genus might be described albeit under different names. Although open nomenclature has been used here to account for taxonomic uncertainties, the stratigraphic ranges of most described species have been extended back in time (see Remarks sections); some were even previously unknown from the Central Indo-Pacific coral fossil record. Diversity of morphospecies varies from 33 in the Calagasan Formation (shale) to only five in the Trankalan/Binaguiohan Limestone. This difference most likely relates to the number of samples available from each formation/limestone (Figure 12, Table 7).

The new fossil collection, despite yielding less diversity than recent studies of the Central IndoPacific fossil corals by McMonagle $(2011,2012)$ (51 genera described), Bromfield (2013) (41 genera described) and Santodomingo (2015b) (38 genera described), provides new taxonomic information that improves our understanding of coral diversity during the poorly studied Chattian - Aquitanian interval. Coupled with known coral fossil records from the PBDB and recent taxonomic stud-

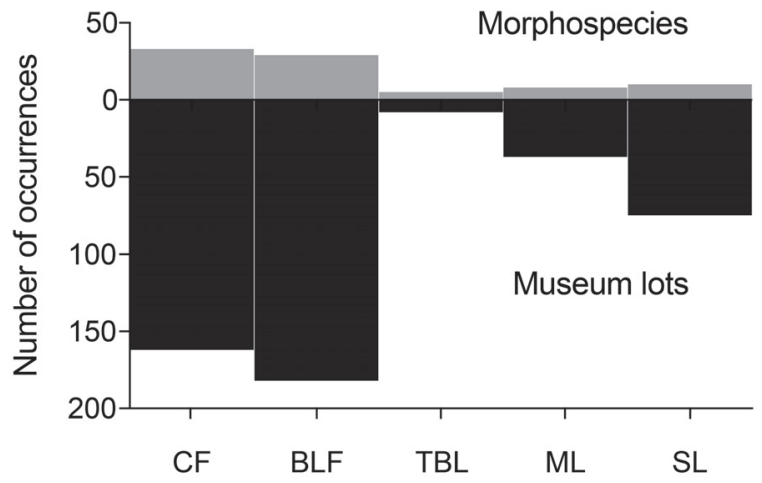

FIGURE 12. The number of morphospecies relative to the number of museum lots in different geologic formations. Geologic formation abbreviations: CF - Calagasan Formation, BLF - Butong Limestone Formation, TBL - Trankalan/Binaguiohan Limestone, ML Melinau Limestone, SL - Subis Limestone.

ies of the Central Indo-Pacific fossils, the herein described fossil collection refines the origin of the Central Indo-Pacific hotspot to $\sim 28 \mathrm{My}$, which is 5 My before previously thought (Renema et al., 2008; Mihaljević et al., 2017). It seems that the interplay of global sea level and local tectonics drove the increase of the availability of suitable and diverse habitats, which promoted coral diversification in the Central Indo-Pacific biodiversity hotspot (Renema et al., 2008; Mihaljević et al., 2014, 2017). Moreover, both processes of speciation (corresponding with the Centre of Origin model) and immigration (corresponding with the Centre of Accumulation model) contribute to the origin of the Central Indo-Pacific biodiversity hotspot (Mihaljević et al., 2017), supporting the theory that origination of the hotspot is complex and cannot be explained by a single model (Rosen, 1984; Palumbi, 1997; Bellwood and Wainwright, 2002; Barber and Bellwood, 2005; Cowman and Bellwood, 2011; Bellwood and Renema, 2012). Interestingly taxonomic and functional diversity have been found decoupled (Mihaljević et al., 2017). As the taxonomic diversity gradually but constantly increases from the beginning of the Eocene, functional diversity remains constant, which suggests increase in functional redundancy. High functional redundancy is often associated with stable ecosystems (Fonseca and Ganade, 2001; Guillemot et al., 2011) and might have contributed to the persistence of the hotspot for over $\sim 28$ My (Mihaljević et al., 2017).

Analysis of similarities (ANOSIM) based on relative abundance of morphospecies in each site 
TABLE 7. Checklist of described material from Malaysia and the Philippines and the formation in which they were found. Numbers represent number of museum lots. Geologic formation abbreviations: CF - Calagasan Formation, BLF - Butong Limestone Formation, TBL - Trankalan/Binaguiohan Limestone, ML - Melinau Limestone, SL - Subis Limestone

\begin{tabular}{|c|c|c|c|c|c|}
\hline Taxon & CF & BLF & TBL & ML & SL \\
\hline $\begin{array}{l}\text { Acanthastrea cf. } \\
\text { echinata }\end{array}$ & 3 & 1 & 0 & 1 & 0 \\
\hline Acanthastrea sp. A & 2 & 0 & 0 & 0 & 0 \\
\hline Acropora sp. A & 1 & 7 & 0 & 0 & 0 \\
\hline Acropora sp. B & 5 & 5 & 0 & 0 & 0 \\
\hline $\begin{array}{l}\text { Actinastrea cf. } \\
\text { minutissima }\end{array}$ & 38 & 24 & 0 & 0 & 0 \\
\hline $\begin{array}{l}\text { Alveopora cf. } \\
\text { fenestrata }\end{array}$ & 0 & 0 & 0 & 2 & 0 \\
\hline Astrea sp. A & 2 & 0 & 0 & 0 & 0 \\
\hline Astrea sp. B & 0 & 1 & 0 & 0 & 0 \\
\hline Astrea sp. C & 0 & 0 & 0 & 0 & 2 \\
\hline $\begin{array}{l}\text { Astreopora cf. } \\
\text { digitata }\end{array}$ & 0 & 0 & 0 & 0 & 9 \\
\hline $\begin{array}{l}\text { Astreopora cf. } \\
\text { expansa }\end{array}$ & 0 & 1 & 0 & 0 & 0 \\
\hline $\begin{array}{l}\text { Blastomussa cf. } \\
\text { simplicitexta }\end{array}$ & 0 & 0 & 1 & 0 & 0 \\
\hline Coelastrea sp. A & 0 & 4 & 0 & 0 & 0 \\
\hline $\begin{array}{l}\text { Cyphastrea cf. } \\
\text { serailia }\end{array}$ & 4 & 9 & 0 & 0 & 0 \\
\hline Cyphastrea sp. A & 1 & 0 & 0 & 0 & 0 \\
\hline $\begin{array}{l}\text { Dictyaraea cf. } \\
\text { anomala }\end{array}$ & 0 & 1 & 0 & 0 & 0 \\
\hline $\begin{array}{l}\text { Dictyaraea cf. } \\
\text { micrantha }\end{array}$ & 1 & 4 & 0 & 0 & 0 \\
\hline $\begin{array}{l}\text { Dipsastraea cf. } \\
\text { speciosa }\end{array}$ & 3 & 2 & 2 & 0 & 23 \\
\hline Dipsastraea sp. A & 4 & 0 & 0 & 0 & 0 \\
\hline Dipsastraea sp. B & 0 & 1 & 0 & 0 & 0 \\
\hline Favites cf. chinensis & 6 & 1 & 0 & 0 & 0 \\
\hline $\begin{array}{l}\text { Favites cf. } \\
\text { pentagona tenuis }\end{array}$ & 1 & 0 & 0 & 0 & 0 \\
\hline Favites sp. A & 5 & 0 & 0 & 0 & 0 \\
\hline Favites sp. B & 2 & 1 & 0 & 0 & 0 \\
\hline Favites spp. & 0 & 0 & 0 & 7 & 14 \\
\hline
\end{tabular}

\begin{tabular}{|c|c|c|c|c|c|}
\hline Taxon & CF & BLF & TBL & ML & SL \\
\hline Fungia spp. & 3 & 0 & 0 & 1 & 0 \\
\hline Galaxea sp. A & 3 & 0 & 0 & 0 & 2 \\
\hline $\begin{array}{l}\text { Gardineroseris cf. } \\
\text { planulata }\end{array}$ & 0 & 1 & 0 & 0 & 0 \\
\hline $\begin{array}{l}\text { Goniastrea cf. } \\
\text { stelligera }\end{array}$ & 1 & 9 & 0 & 0 & 0 \\
\hline $\begin{array}{l}\text { Goniopora cf. } \\
\text { palmensis }\end{array}$ & 2 & 7 & 0 & 0 & 0 \\
\hline $\begin{array}{l}\text { Goniopora cf. } \\
\text { planulata }\end{array}$ & 5 & 8 & 0 & 0 & 0 \\
\hline $\begin{array}{l}\text { Goniopora cf. } \\
\text { tenuidens }\end{array}$ & 1 & 0 & 0 & 0 & 0 \\
\hline $\begin{array}{l}\text { Hydnophora cf. } \\
\text { microconos }\end{array}$ & 11 & 1 & 0 & 15 & 14 \\
\hline $\begin{array}{l}\text { Leptastrea cf. } \\
\text { transversa }\end{array}$ & 11 & 1 & 0 & 0 & 0 \\
\hline Leptastrea sp. A & 4 & 0 & 0 & 0 & 0 \\
\hline Leptoria cf. phrygia & 0 & 1 & 0 & 7 & 2 \\
\hline Leptoseris sp. A & 0 & 1 & 0 & 0 & 0 \\
\hline $\begin{array}{l}\text { Lobophyllia cf. } \\
\text { hemprichii }\end{array}$ & 4 & 0 & 0 & 0 & 0 \\
\hline Pachyseris spp. & 1 & 58 & 0 & 0 & 0 \\
\hline $\begin{array}{l}\text { Paramontastraea sp. } \\
\text { A }\end{array}$ & 0 & 0 & 0 & 3 & 0 \\
\hline Pavona cf. clavus & 1 & 0 & 0 & 0 & 2 \\
\hline Pavona cf. venosa & 0 & 7 & 0 & 0 & 0 \\
\hline $\begin{array}{l}\text { Platygyra cf. } \\
\text { lamellina }\end{array}$ & 25 & 1 & 2 & 0 & 1 \\
\hline Porites sp. A & 0 & 0 & 1 & 0 & 0 \\
\hline Porites spp. & 1 & 4 & 2 & 0 & 6 \\
\hline $\begin{array}{l}\text { Stylophora cf. } \\
\text { pistillata }\end{array}$ & 4 & 13 & 0 & 0 & 0 \\
\hline Stylophora spp. & 1 & 7 & 0 & 1 & 0 \\
\hline $\begin{array}{l}\text { Trachyphyllia cf. } \\
\text { constricta }\end{array}$ & 5 & 0 & 0 & 0 & 0 \\
\hline $\begin{array}{l}\text { Trochocyathus cf. } \\
\text { schmidti }\end{array}$ & 1 & 1 & 0 & 0 & 0 \\
\hline
\end{tabular}

shows a statistically significant difference $(R=$ $0.36, p=0.02$ ) between Chattian and Aquitanian coral communities. Moreover, hierarchical cluster analysis shows that species composition in Chattian sites is overall more similar to each other than to Aquitanian species composition (Figure 13). In comparison, host lithologies do not seem to influ-

ence the composition of coral communities $(R=$ $0.02, p=0.35)$. This is surprising because different lithologies suggest different environmental conditions, which would be expected to support different community compositions. However, 20 out of 49 described morphospecies (44 morphospecies + 5 spp. taxa) belong to family Merulinidae (Figure 14), 


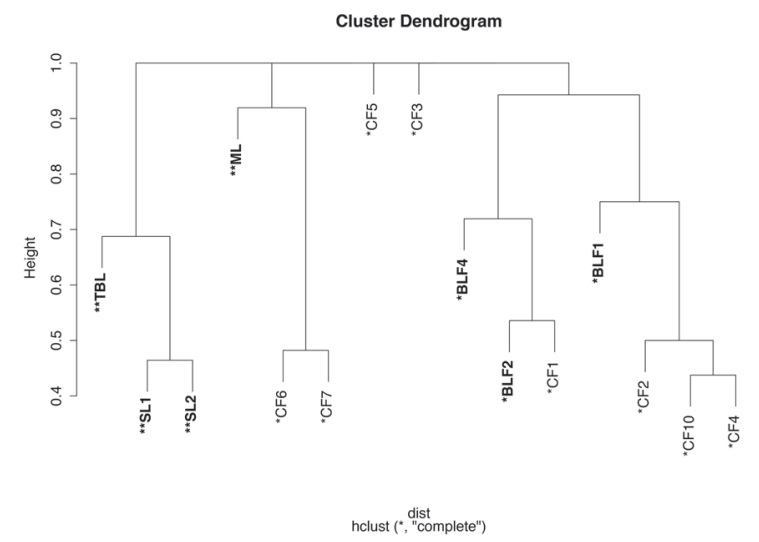

FIGURE 13. Cluster dendogram for coral communities (morphospecies level) in each site. Geologic formation abbreviations: CF - Calagasan Formation, BLF Butong Limestone Formation, TBL - Trankalan/Binaguiohan Limestone, ML - Melinau Limestone, SL - Subis Limestone, bold - limestone formations, Chattian - *, Aquitanian $-{ }^{* *}$.

which is mostly characterized by massive colonies and medium-sized corallites. All merulinid species described here have encrusting to massive colony shapes, which are resistant to higher hydrodynamic energy and higher sedimentation (Chappell, 1980; Jackson and Hughes, 1985; Soong, 1993; Rachello-Dolmen and Cleary, 2007); therefore, they are often found in marginal environments (Sommer et al., 2014). Moreover, Santodomingo et al. (2016) suggest that challenging habitats (e.g., turbid habitats) might have played an important role in the early diversification of coral in the Central Indo-Pacific.

The high number of massive morphospecies might be a result of the effects of different taphonomic processes on different coral morphologies (e.g., branching and massive) (Greenstein and

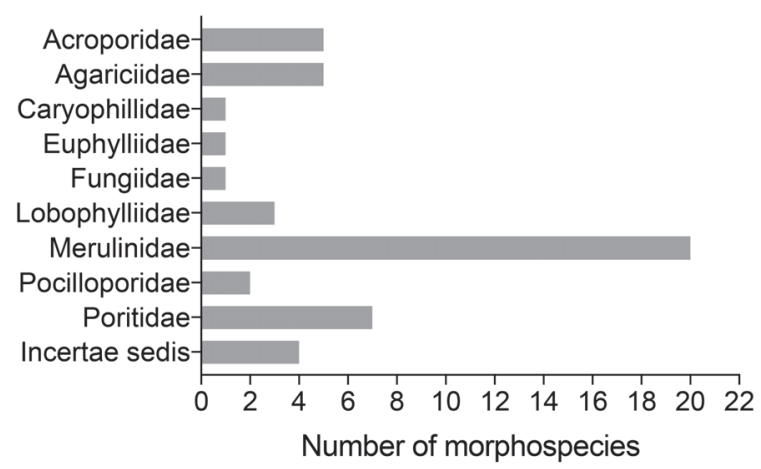

FIGURE 14. The number of morphospecies described from each coral family.
Pandolfi, 1997). However, ANOSIM based on relative abundance of colony morphologies in each site shows no statistically significant difference between different lithologies $(R=-0.02, p=0.45)$. Nevertheless, only two morphospecies (Stylophora spp. and Porites sp. A) with branching morphologies were identified from well-indurated formations, such as the dense limestone matrix of Trankalan/ Binaguiohan, Melinau and Subis Limestones (Figure 15). From the fourth studied limestone formation, Butong Limestone Formation, characterized by relatively less well-indurated limestone matrix, nine morphospecies with branching colony morphologies were described. The presence of branching colonies in the three dense limestone formations can be confirmed from the cross-sections through the rock where the rough outline of the branches and spongy skeleton is visible. However, the original coral skeleton is highly recrystallized, and the outer surface of the branches is generally indistinguishable from the surrounding limestone matrix preventing taxonomic identification of the coral fragments.

Variation of preservation quality based on lithology of the matrix containing coral fragments has been one of the major challenges in identifying corals described herein. This kind of variation is most apparent in Porites spp. (Figure 11.1-4) where it prevents identification beyond the genus level. Even within the same matrix, preservation quality can strongly vary, as it can also within the same coral colony, e.g., Actinastrea cf. minutissima (Figure 11.5-6) and Favites spp. (Figure 7.6-7). Because preservation quality cannot be improved, it is essential to look at many samples to understand the variation in preservation. To make sure that one evaluates variation in the preservation within the same (morpho) species, it is good to start with the observation of the preservation variation within a single colony. The surface of most coral colonies is not smooth and flat but has uneven and complex relief. Therefore, not all of the corallites are exposed to the same amount of erosion and, subsequently, vary in their quality of preservation.

Despite these challenges, the new fossil collection presented here progresses our understanding of the diversity and morphological variation within scleractinian corals during the time of the origin of the Indo-Pacific marine biodiversity hotspot. The taxonomic description of fossil corals is fundamental for studying both taxonomic and functional diversity in deep time. This study demonstrates that in the time of the origin of the Indo-Pacific 


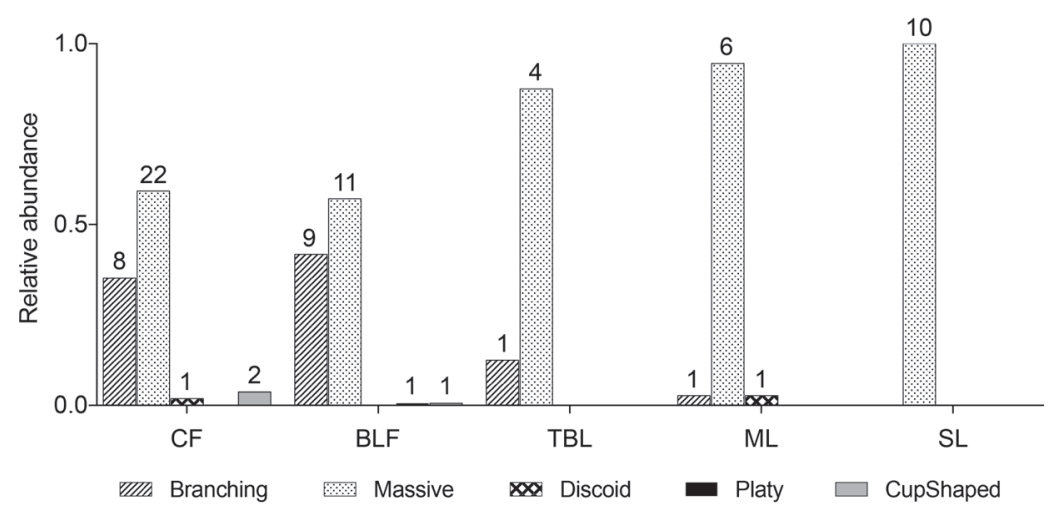

FIGURE 15. Relative abundance of colony shapes within each studied formation. Numbers above the bars represent absolute number of morphospecies. Geologic formation abbreviations: CF - Calagasan Formation, BLF - Butong Limestone Formation, TBL - Trankalan/Binaguiohan Limestone, ML - Melinau Limestone, SL - Subis Limestone.

marine diversity hotspot scleractinians were well established and more diverse than previously thought. The new collection not only extends temporal ranges of coral genera in the Central IndoPacific but provides new information on their spatial distributions that can be employed in future biogeographical studies. If put into environmental context, our extended knowledge of scleractinian diversity and morphological variation through time could provide further information about past coral assemblages, which could potentially offer clues about the future of coral reef communities and hotspot development.

\section{ACKNOWLEDGMENTS}

I acknowledge financial contributions from Petroliam Nasional Berhad (Petronas), Pearl Energy, the University of Queensland (UQ) International Scholarship (UQI) 2011-2014, the UQ Collaboration and Industry Engagement Fund, UQ Centre for Marine Science and the Australian Research Council Centre of Excellence for Coral Reef Studies. Special thanks to R. Day for financial support allowing completion of the manuscript. I also thank the State Planning Unit in Kuching, Malaysia, for allowing us to conduct research in Sarawak, and the National Parks and Nature Reserves for a research permit for the Gunung Mulu National Park. Special thanks for logistical, physical, and all other help during seven field trips in Sarawak, Malaysia and Islands Cebu and Negros, Philippines: K. Welsh, W. Renema, the Gunung Mulu National Park staff (especially B. Clark), L. Southwell, Hollystone Quarry Sdn. Bhd. staff, people from Long Jeh community, B. Beck, K. K. Ting, A. O'Dea, Mines and Geosciences Bureau in Manila and Mandaue City (especially Y. Aguilar and A.R. Lucero), F.G. Nepomucedo, J. CoatesMarnane and M. del C. Gómez-Cabrera. I would like to thank J.M. Pandolfi, N. Santodomingo, J. Keyse, G. Webb, A. Hunter, J. Claus and one anonymous reviewer for their comments on earlier versions of this manuscript. They have tremendously improved the manuscript. Moreover, special thanks to G. Webb for his support and encouragement in finalising this study and manuscript.

\section{REFERENCES}

Adams, C.G. 1965. The foraminifera and stratigraphy of the Melinau Limestone, Sarawak, and its importance in Tertiary correlation. Quarterly Journal of the Geological Society, 121:283-338. https://doi.org/10.1144/gsjgs.121.1.0283

Adams, C.G. and Haak, R. 1962. The stratigraphical succession in the Batu Gading area, Middle Baram, north Sarawak. The Geology and Mineral Resources of the Suai-Baram area, North Sarawak, Geological Survey Department, British Territories in Borneo, Memoir 13:141-150.

Adrain, J.M. 2001. Systematic paleontology. Journal of Paleontology, 75:1055-1057. https:// doi.org/10.1017/s002233600001711x 
Alfaro, M.E., Santini, F., and Brock, C.D. 2007. Do reefs drive diversification in marine teleosts? Evidence from the pufferfishes and their allies (Order Tetraodontiformes). Evolution, 61:2104-2126. https://doi.org/10.1111/j.1558-5646.2007.00182.x

Alloiteau, J. 1952. Embranchement des coelentérés, p. 376-684. In Piveteau, J. (ed.), Traité de Paléontologie. Tome premier. Masson, Paris.

Arrigoni, R., Terraneo, I.T., Galli, P., and Benzoni, F. 2014. Lobophylliidae (Cnidaria, Scleractinia) reshuffled: pervasive non-monophyly at genus level. Molecular Phylogenetics and Evolution, 73:60-64. https://doi.org/10.1016/j.ympev.2014.01.010

Audouin, V. 1826. Madrépores, p. 77-98. In Savigny, J.C. (ed.), Explication Sommaire des Planches de Polypes de l'Egypte et de la Syrie; Offrant un Exposé des Caractères Naturels des Genres, avec la Distinction des Espèces. De L'imprimerie Impériale, Paris.

Aurelio, M.A. and Peña, R.E. 2010. Geology of the Philippines. Mines and Geoscience Bureau, Manila.

Barber, P. H. 2009. The challenge of understanding the Coral Triangle biodiversity hotspot. Journal of Biogeography, 36:1845-1846. https://doi.org/10.1111/j.1365-2699.2009.02198.x

Barber, P.H. and Bellwood, D.R. 2005. Biodiversity hotspots: evolutionary origins of biodiversity in wrasses (Halichoeres: Labridae) in the Indo-Pacific and new world tropics. Molecular Phylogenetics and Evolution, 35:235-253. https://doi.org/10.1016/j.ympev.2004.10.004

Barnes, E., Aurelio, M.A., Muller, C., Pubellier, M., Quebral, R.D., and Rangib, C. 1958. Geology and Coal Resources of the Argao-Dalaguete Region, Cebu. Bureau of Mines, Manila.

Bedot, M. 1907. Madréporaires d'Amboine. Revue Suisse de Zoologie, 15:143-292.

Belasky, P. 1996. Biogeography of Indo-Pacific larger foraminifera and scleractinian corals: A probabilistic approach to estimating taxonomic diversity, faunal similarity, and sampling bias. Palaeogeography, Palaeoclimatology, Palaeoecology, 122:119-141. https://doi.org/10.1016/ 0031-0182(95)00092-5

Bellwood, D.R., Klanten, S., Cowman, P.F., Pratchett, M.S., Konow, N., and van Herwerden, L. 2010. Evolutionary history of the butterflyfishes ( $\mathrm{f}$ : Chaetodontidae) and the rise of coral feeding fishes. Journal of Evolutionary Biology, 23:335-349. https://doi.org/10.1111/j.14209101.2009.01904.x

Bellwood, D.R. and Meyer, C.P. 2009. Searching for heat in a marine biodiversity hotspot. Journal of Biogeography, 36:569-576. https://doi.org/10.1111/j.1365-2699.2008.02029.x

Bellwood, D.R. and Renema, W. 2012. Biodiversity hotspots, evolution and coral reef biogeography, p. 216-245. In Gower, J.C., Johnson, K.G., Richardson, J.E., Rosen, B.R., Rüber, L., Williams, and S.T. (eds.), Biotic Evolution and Environmental Change in Southeast Asia. Cambridge University Press, New York. https://doi.org/10.1017/ cbo9780511735882.011

Bellwood, D.R. and Wainwright, P.C. 2002. The history and biogeography of fishes on coral reefs, p. 5-32. In Sale, P.F. (ed.), Coral Reef Fishes Dynamic and Diversity in a Complex Ecosystem. Elsevier, San Diego. https://doi.org/10.1016/b978-012615185-5/50003-7

Bengtson, P. 1988. Open nomenclature. Palaeontology, 31:223-227.

Benton, M.J. and Emerson, B.C. 2007. How did life become so diverse? The dynamics of diversification according to the fossil record and molecular phylogenetics. Palaeontology, 50:23-40. https://doi.org/10.1111/j.1475-4983.2006.00612.x

Benzoni, F., Arrigoni, R., Waheed, Z., and Stefani, F. 2014. Phylogenetic relationships and revision of the genus Blastomussa (Cnidaria: Anthozoa: Scleractinia) with description of a new species. Raffles Bulletin of Zoology, 62:358-378.

Bernard, H.M. 1903. The family Poritidae, I, The genus Goniopora. L. Catalogue of the Madreporarian Corals in the British Museum Natural History, 4:1-206.

Blair, J.E. and Hedges, S.B. 2005. Molecular phylogeny and divergence times of deuterostome animals. Molecular Biology and Evolution, 22:2275-2284. https://doi.org/10.1093/molbev/ msi225

Boekschoten, J.G., Best, M.B., Oosterbaan, A., and Molenkamp, F.M. 1989. Past corals and recent reefs in Indonesia. Netherlands Journal of Sea Research, 23:117-122. https://doi.org/ 10.1016/0077-7579(89)90006-9

Briggs, J.C. 1992. The marine East Indies: centre of origin? Global Ecology and Biogeography Letters, 2:149-156. https://doi.org/10.2307/2997803

Bromfield, K. 2013. Neogene corals from the Indo-Pacific: Indonesia, Papua New Guinea, and Fiji. Bulletins of American Paleontology, 387:1-136. 
Bromfield, K. and Pandolfi, J.M. 2011. Regional patterns of evolutionary turnover in Neogene coral reefs from the central Indo-West Pacific Ocean. Evolutionary Ecology, 26:375-391. https://doi.org/10.1007/s10682-011-9483-9

Brüggemann, F. 1877. Notes on the stony corals in the collection of the British Museum. I. Description of two new species of Turbinariidae. II. Remarks on the species of Seriatopora. Annals and Magazine of Natural History, Series 4, 19:415-421.

Budd, A.F., Foster, C.T., Dawson, J.P., and Johnson, K.G. 2001. The Neogene marine biota of tropical America ("NMITA") database: accounting for biodiversity in paleontology. Journal of Paleontology, 75:743-751. https://doi.org/10.1017/s0022336000039779

Budd, A.F., Fukami, H., Smith, N.D., and Knowlton, N. 2012. Taxonomic classification of the reef coral family Mussidae (Cnidaria: Anthozoa: Scleractinia). Zoological Journal of the Linnean Society, 166:465-529. https://doi.org/10.1111/j.1096-3642.2012.00855.x

Budd, A.F. and Stolarski, J. 2009. Searching for new morphological characters in the systematics of scleractinian reef corals: comparison of septal teeth and granules between Atlantic and Pacific Mussidae. Acta Zoologica, 90:142-165. https://doi.org/10.1111/j.14636395.2008.00345.x

Cairns, S.D. and Kitahara, M. 2012. An illustrated key to the genera and subgenera of the recent azooxanthellate Scleractinia (Cnidaria, Anthozoa), with an attached glossary. ZooKeys, 227:1-47. https://doi.org/10.3897/zookeys.227.3612

Carpenter, K.E., Abrar, M., Aeby, G., Aronson, R.B., Banks, S., Bruckner, A., Chiriboga, A., Cortés, J., Delbeek, J.C., DeVantier, L., Edgar, G.J., Edwards, A.J., Fenner, D., Guzmán, H.M., Hoeksema, B.W., Hodgson, G., Johan, O., Licuanan, W.Y., Livingstone, S.R., Lovell, E.R., Moore, J.A., Obura, D.O., Ochavillo, D., Polidoro, B.A., Precht, W.F., Quibilan, M.C., Reboton, C., Richards, Z.T., Rogers, A.D., Sanciangco, J., Sheppard, A., Sheppard, C., Smith, J., Stuart, S., Turak, E., Veron, J.E.N., Wallace, C.C., Weil, E., and Wood, E.M. 2008. One-third of reef-building corals face elevated extinction risk from climate change and local impacts. Science, 321:560-563. https://doi.org/10.1126/science.1159196

Chappell, J. 1980. Coral morphology, diversity and reef growth. Nature, 286:249-252. https:// doi.org/10.1038/286249a0

Clarke, K.R. 1993. Non-parametric multivariate analyses of changes in community structure. Australian Journal of Ecology, 18:117-143. https://doi.org/10.1111/j.14429993.1993.tb00438.x

Cornée, J.-J., Villeneuve, M., Ferrandini, M., Hinschberger, F., Malod, J., Matsumaru, K., RibaudLaurenti, A. and Rehault, J.-P. 2002. Oligocene reefal deposits in the Pisang Ridge and the origin of the Lucipara Block (Banda Sea, eastern Indonesia). Geo-Marine Letters, 22:66-74. https://doi.org/10.1007/s00367-002-0099-5

Cowman, P.F. and Bellwood, D.R. 2011. Coral reefs as drivers of cladogenesis: expanding coral reefs, cryptic extinction events, and the development of biodiversity hotspots. Journal of Evolutionary Biology, 24:2543-2562. https://doi.org/10.1111/j.1420-9101.2011.02391.x

Cowman, P.F., Bellwood, D.R. and van Herwerden, L. 2009. Dating the evolutionary origins of wrasse lineages (Labridae) and the rise of trophic novelty on coral reefs. Molecular Phylogenetics and Evolution, 52:621-631. https://doi.org/10.1016/j.ympev.2009.05.015

Cuif, J.-P. and Perrin, C. 1999. Micromorphology and microstructure as expressions of scleractinian skeletogenesis in Favia fragum (Esper, 1795) (Faviidae, Scleractinia). Zoosystema, 21:137-156.

Dana, J.D. 1846. Zoophytes. Volume VII of the United States Exploring Expedition during the Years 1838, 1839, 1840, 1841, 1842, under the Command of Charles Wilkes, USN. Lea and Blanchard, Philadelphia.

de Blainville, H.M. 1830. Zoophytes, p. 1-548. In Levrault, F.G. (ed.), Dictionnaire des Sciences Naturelles, dans Lequel on Traitre Méthodiquement des Différents Êtres de la Nature, Considérés Soit en Eux-Mêmes, d'Après l'État Actuel de nos Connaissances, soit Relativement à l'Utlité qu'en Peuvent Retirer la Médicine, l'Agriculture, le Commerce et les Arts. Le Normat, Paris.

Donoghue, P.C.J. and Benton, M.J. 2007. Rocks and clocks: calibrating the Tree of Life using fossils and molecules. Trends in Ecology and Evolution, 22:424-431. https://doi.org/10.1016/ j.tree.2007.05.005

Duncan, P.M. 1863. On the fossil corals of the West Indian islands. Part 1. Quarterly Journal of the Geological Society, 19:406-458. https://doi.org/10.1144/gsl.jgs.1863.019.01-02.40 
Duncan, P.M. 1864. On the fossil corals of the West Indian islands. Part 2. Quarterly Journal of the Geological Society, 20:20-44. https://doi.org/10.1144/gsl.jgs.1864.020.01-02.09

Dustan, P., Doherty, O., and Pardede, S. 2013. Digital reef rugosity estimates coral reef habitat complexity. PLoS ONE, 8:e57386. https://doi.org/10.1371/journal.pone.0057386

Eguchi, M. 1935. On the corals and coral reefs of the Palau Islands. Contributions from the Institute of Geology and Paleontology, Tohoku Imperial University, Sendai, 16:1-13.

Ehrenberg, C.G. 1834. Beiträge zur physiologischen Kenntniss der Corallenthiere im allgemeinen, und besonders des rothen Meeres, nebst einem Versuche zur physiologischen Systematik derselben. Abhandlungen der Königlichen Akademie der Wissenschaften, Berlin, 1:225-380.

Ekman, S.P. 1953. Zoogeography of the Sea. Sidgwick and Jackson, London.

Ellis, J. and Solander, D. 1786. The Natural History of Many Curious and Uncommon Zoophytes, Collected from Various Parts of the Globe. Benjamin White and Son, London.

Ellison, A.M., Farnsworth, E.J., and Merkt, R.E. 1999. Origins of mangrove ecosystems and the mangrove biodiversity anomaly. Global Ecology and Biogeography, 8:95-115. https://doi.org/ 10.1046/j.1466-822x.1999.00126.x

Esper, E.J.C. 1788-1830. Die Pflanzenthiere in Abbildugen nach der Natur mit Farben erleuchtet nebst Beschreibungen. Raspischen Buchhandlung, Nürnberg.

Esper, E.J.C. 1794-1806. Fortsetzungen der Pflanzenthiere in Abbildungennach der Natur mit Farben erleuchtet nebst Beschreibungen. Raspischen Buchhandlung, Nürnberg.

Felix, J. 1913. Die fossilen Anthozoen aus der Umgebung von Trinil. Palaeontographica, 60:311365.

Felix, J. 1915. Jungtertiäre und quartäre Anthozoen von Timor und Obi, 1. Teil. Paläontologie von Timor, 2:3-45.

Felix, J. 1921. Fossile Anthozoen von Borneo. Paläontologie von Timor, 9:1-64.

Fonseca, C.R. and Ganade, G. 2001. Species functional redundancy, random extinctions and the stability of ecosystems. Journal of Ecology, 89:118-125. https://doi.org/10.1046/j.13652745.2001.00528.x

Forskål, P. 1775. Descriptiones Animalium Avium, Amphibiorum, Piscium, Insectorum, Vermium; Quæ in Itinere Orientali Observavit Petrus Forskål. Heineck et Faber, Hauniae.

Fukami, H., Chen, C.A., Budd, A.F., Collins, A., Wallace, C.C., Chuang, Y.-Y., Chen, C., Dai, C.F., Iwao, K., Sheppard, C., and Knowlton, N. 2008. Mitochondrial and nuclear genes suggest that stony corals are monophyletic but most families of stony corals are not (Order Scleractinia, Class Anthozoa, Phylum Cnidaria). PLoS ONE, 3:e3222. https://doi.org/ 10.1371/journal.pone.0003222

Gardiner, J.S. 1898. On the fungid corals collected by the author in the South Pacific. Proceedings of the Zoological Society of London, 3:525-539. https://doi.org/10.1111/j.10963642.1898.tb03173.x

Gardiner, J.S. 1904. The Fauna and Geography of the Maldive and Laccadive Archipelagoes. Madreporaria I. Introduction II. Astraeidae. University Press, Cambridge.

Gardiner, J.S. 1905. The Fauna and Geography of the Maldive and Laccadive Archipelagoes. Madreporaria III. Fungida IV. Turbinolidae. University Press, Cambridge.

Gerth, H. 1921a. Anthozoen von Java. Sammlungen des Geologischen Reichs-Museums in Leiden, 2:387-445.

Gerth, H. 1921b. Coelenterata, p. 387-445. In Martin, K. (ed.), Die Fossilien von Java auf Grund einer Sammlung von Dr. RDM Verbeek und von Anderen. Buchhandlung und Druckerei vormals EJ Brill, Leiden.

Gerth, H. 1923. Die Anthozoenfauna des Jungtertiärs von Borneo. Sammlungen des Geologischen Reichs-Museums in Leiden, 10:37-136.

Gerth, H. 1925. Jungtertiäre Korallen von Nias, Java und Borneo, nebst einer Uebersicht über die as dem Känozoikum des Indischen Archipels bekannten Arten. Leidsche Geologische Mededeelingen, 1:22-82.

Gerth, H. 1931. Onze palaeontologische kennis van Nederlansche Oost-Indië in 1930. 5. Coelenterata. Leidsche Geologische Mededeelingen, 5:115-119.

Gerth, H. 1933. Neue Beiträge zur Kenntnis der Korallenfauna des Tertiärs von Java. 1. Die Korallen des Eocaen und des älteren Neogeen. Dienst van den Mijnbouw in NederlandschIndie. Wetenschappelijke Mededeelingen, 25:1-45. 
Greenstein, B.J. and Pandolfi, J.M. 1997. Preservation of community structure in modern reef coral life and death assemblages of the Florida Keys: Implications for the Quaternary fossil record of coral reefs. Bulletin of Marine Science, 61:431-452.

Gregory, J.W. and Trench, J.B. 1916. Eocene corals from the Fly River, Central New Guinea. Geological Magazine (Decade VI), 3:481-488. https://doi.org/10.1017/s0016756800208297

Guillemot, N., Kulbicki, M., Chabanet, P., and Vigliola, L. 2011. Functional redundancy patterns reveal non-random assembly rules in a species-rich marine assemblage. PLoS ONE, 6:e26735-15. https://doi.org/10.1371/journal.pone.0026735

Hedges, S.B., Parker, P.H., Sibley, C.G., and Kumar, S. 1996. Continental breakup and the ordinal diversification of birds and mammals. Nature, 381:226-229. https://doi.org/10.1038/ $381226 \mathrm{a} 0$

Hoeksema, B.W. 1989. Taxonomy, phylogeny and biogeography of mushroom corals (Scleractinia: Fungiidae). Zoologische Verhandelingen, 254:1-295.

Hoeksema, B.W. 2007. Delineation of the Indo-Malayan centre of maximum marine biodiversity: the Coral Triangle, p. 117-178. In Renema, W. (ed.), Biogeography, Time, and Place: Distributions, Barriers, and Islands. Springer, Dordrecht. https://doi.org/10.1007/978-1-40206374-9_5

Hoeksema, B.W. and Cairns, S.D. 2014. World Register of Marine Species. http:// www.marinespecies.org

Huang, D., Benzoni, F., Fukami, H., Knowlton, N., Smith, N.D., and Budd, A.F. 2014. Taxonomic classification of the reef coral families Merulinidae, Montastraeidae, and Diploastraeidae (Cnidaria: Anthozoa: Scleractinia). Zoological Journal of the Linnean Society, 171:277-355. https://doi.org/10.1111/zoj12140

Huang, D., Goldberg, E.E., Chou, L.M., and Roy, K. 2018. The origin and evolution of coral species richness in a marine biodiversity hotspot. Evolution, 72:288-302. https://doi.org/ 10.1111/evo.13402

Humblet, M., Hongo, C., and Sugihara, K. 2014. An identification guide to some major Quaternary fossil reef-building coral genera (Acropora, Isopora, Montipora, and Porites). Island Arc, 24:16-30. https://doi.org/10.1111/iar.12077

Jackson, J.B.C. and Erwin, D.H. 2006. What can we learn about ecology and evolution from the fossil record? Trends in Ecology and Evolution, 21:322-328. https://doi.org/10.1016/ j.tree.2006.03.017

Jackson, J.B.C. and Johnson, K.G. 2000. Life in the last few million years. Paleobiology, 26:221235. https://doi.org/10.1017/s0094837300026944

Jackson, J.B.C. and Hughes, T.P. 1985. Adaptive strategies of coral-reef invertebrates: coralreef environments that are regularly disturbed by storms and by predation often favor the very organisms most susceptible to damage by these processes. American Scientist, 73:265-274.

Johnson, K.G., Hasibuan, F., Müller, W., and Todd, J.A. 2015. Biotic and environmental origins of the Southeast Asian marine biodiversity hotspot: The Throughflow Project. PALAIOS, 30:1-6. https://doi.org/10.2110/palo.2014.103

Jokiel, P. and Martinelli, F.J. 1992. The vortex model of coral reef biogeography. Journal of Biogeography, 19:449-458. https://doi.org/10.2307/2845572

Jordan, C.F. Jr and Abdullah, M. 1992. Arun field-Indonesia North Sumatra basin, Sumatra. AAPG Treatise on Petroleum Geology, Stratigraphic Traps III, 1-39.

Jurgan, H. and Domingo, R.M.A. 1989. Younger Tertiary limestone formations in the Visayan Basin, Philippines, p. 207-276. In Porth, H. and von Daniels, C.H. (eds.), On the Geology and Hydrocarbon Prospects of the Visayan Basin, Philippines. Geologisches Jahrbuch, Band B, Hannover.

Kay, E.A. 1996. Origin and evolutionary radiation of the Mollusca, p. 211-220. In Taylor, J.D. (ed.), Origin and Evolutionary Radiation of the Mollusca. Oxford University Press, USA.

Keith, S.A., Baird, A.H., Hughes, T.P., Madin, J.S., and Connolly, S.R. 2013. Faunal breaks and species composition of Indo-Pacific corals: the role of plate tectonics, environment and habitat distribution. Proceedings of the Royal Society B: Biological Sciences, 280:20130818. https://doi.org/10.1098/rspb.2013.0818

Kitahara, M.V., Stolarski, J., Cairns, S.D., Benzoni, F., Stake, J.L., and Miller, D.J. 2012. The first modern solitary Agariciidae (Anthozoa, Scleractinia) revealed by molecular and microstructural analysis. Invertebrate Systematics, 26:303. https://doi.org/10.1071/is11053 
Klunzinger, C.B. 1879. Die Korallthiere des Rothen Meeres. 3. Theil: Die Steinkorallen. Gutmann, Berlin.

Ladd, H.S. 1960. Origin of the Pacific island molluscan fauna. American Journal of Science, 258A:127-150.

Lamarck, J.B.D. 1816. Histoire Naturelle des Animaux sans Vertèbres, Présentant les Caractères Généraux et Particuliers de ces Animaux, Leur Distribution, Leurs Classes, Leurs Familles, Leurs Genres, et la Citation des Principales Espèces qui s'y Rapportent; Précédée d'une Introduction Offrant la Détermination des Caractères Essentiels de l'Animal, sa Distinction du Végétal et des Autres Corps Naturels, Enfin, l'Exposition des Principes Fondamentaux de la Zoologie. Déterville and Verdière, Paris.

Leloux, J. and Renema, W. 2007. Types and originals of fossil Porifera and Cnidaria of Indonesia in Naturalis. NNM Technical Bulletin, 10:1-215.

Löser, H. 2011. Revision of Actinastrea, the most common Cretaceous coral genus. Paläontologische Zeitschrift, 86:15-22. https://doi.org/10.1007/s12542-011-0110-4

Lunt, P. and Allan, T. 2004. Larger foraminifera in Indonesian biostratigraphy, calibrated to isotopic dating. GRDC Museum Workshop on Micropalaeontology, 1-109.

Lunt, P. and Renema, W. 2014. On the Heterostegina - Tansinhokella - Spiroclypeus lineage in SE Asia. Berita Sedimentologi, 29:6-31.

MacArthur, R.H. and MacArthur, J.W. 1961. On bird species diversity. Ecology, 42:594-598.

Martin, K. 1879. Die Tertiärschichten auf Java. Nach den Entdeckungen von Fr. Junghuhn. E. J. Brill, Leiden.

Martin, K. 1880. Vorwort, Palaeontologischer Theil: Crustacea, Corallia, Foraminifera, Erklärung der Abbildungen, p. 127-164. In Martin, K. (ed.), Die Tertiarschichten auf Java. Nach den Entdeckungen von Fr. Junghuhn. E. J. Brill, Leiden.

Martin, K. 1883. Die Versteinerungs-fuehrenden Sedimente Timors. Sammlungen des Geologischen Reichs-Museums in Leiden, 1:1-64.

McCoy, E.D. and Heck Jr., K.L. 1976. Biogeography of corals, seagrasses, and mangroves: an alternative to the center of origin concept. Systematic Biology, 25:201-210. https://doi.org/ $10.2307 / 2412488$

McMonagle, L.B. 2012. A Diverse Assemblage of Corals from the Late Oligocene of Eastern Sabah, Borneo: Pre-Miocene Origins of the Indo-West Pacifc Marine Biodiversity Hotspot. Unpublished PhD thesis, Durham Univeristy, Durham, UK.

McMonagle, L.B., Lunt, P., Wilson, M.E.J., Johnson, K.G., Manning, C., and Young, J.R. 2011. A re-assessment of age dating of fossiliferous limestones in eastern Sabah, Borneo: Implications for understanding the origins of the Indo-Pacific marine biodiversity hotspot. Palaeogeography, Palaeoclimatology, Palaeoecology, 305:28-42. https://doi.org/10.1016/ j.palaeo.2011.02.009

Mihaljević, M., Korpanty, C., Renema, W., Welsh, K., and Pandolfi, J.M. 2017. Identifying patterns and drivers of coral diversity in the Central Indo-Pacific marine biodiversity hotspot. Paleobiology, 43:343-364. https://doi.org/10.1017/pab.2017.1

Mihaljević, M., Renema, W., Welsh, K. and Pandolfi, J.M. 2014. Eocene-Miocene shallow-water carbonate platforms and increased habitat diversity in Sarawak, Malaysia. PALAIOS, 29:378391. https://doi.org/10.2110/palo.2013.129

Morley, R.J. 2000. Origin and Evolution of Tropical Rain Forests. John Wiley and Sons Inc, Chichester.

Nakamori, T. 1986. Community Structures of Recent and Pleistocene Hermatypic Corals in the Ryukyu Islands, Japan. Tohoku University, Sendai.

Ortmann, A.E. 1889. Beobachtungen an Steinkorallen von der Südküste Ceylons. Zoologische Jahrbüchern, Abteilung für Systematik, Biologie und Biogeographie der Tiere, 4:493-590.

Osberger, R. 1954a. Research on fossil corals from Java. Indonesian Journal for Natural Science, 110:201-205.

Osberger, R. 1954b. Jungtertiäre Korallen von Java, Teil I. Neues Jahrbuch für Geologie und Paläontologie Abhandlungen, 100:119-158.

Osberger, R. 1955. Beschreibung einiger tertiärer Korallen von Java. Neues Jahrbuch für Geologie und Paläontologie Abhandlungen, 6:252-256.

Pallas, P.A. 1766. Elenchus Zoophytorum Sistens Generum Adumbrationes Generaliores et Specierum Cognitarium Succinctas Descriptiones cum Selectis Auctorum Synonymis. Fransiscum Varrentrapp, Hagae. 
Palumbi, S.R. 1997. Molecular biogeography of the Pacific. Coral Reefs, 16:S47-S52. https:// doi.org/10.1007/s003380050241

Pandolfi, J.M. 1992. Successive isolation rather than evolutionary centres for the origination of Indo-Pacific reef corals. Journal of Biogeography, 19:593-609. https://doi.org/10.2307/ 2845703

Pandolfi, J.M. and Minchin, P.R. 1996. A comparison of taxonomic composition and diversity between reef coral life and death assemblages in Madang Lagoon, Papua New Guinea. Palaeogeography, Palaeoclimatology, Palaeoecology, 119:321-341. https://doi.org/10.1016/ 0031-0182(95)00016-x

Patterson, C. 1981. Significance of fossils in determining evolutionary relationships. Annual Review of Ecology and Systematics, 12:195-223. https://doi.org/10.1146/ annurev.es.12.110181.001211

Paulay, G. 1997. Diversity and distribution of reef organisms, p. 298-353. In Birkeland, C.E. (ed.), Life and Death of Coral Reefs. Chapman and Hall, New York.

Perrin, C. 2004. Diagenèse précoce des biocristaux carbonatés: transformations isominérales de l'aragonite corallienne. Bulletin De La Societe Geologique De France, 175:95-106.

Pillai, C.G. 1986. Recent corals from the south-east coast of India, p. 107-109. In James, P.S.B.R. (ed.), Advances in Marine Biology, Today and Tomorrow. Printers and Publishers, New Delhi.

Porth, H. and von Daniels, C.H. 1989. On the geology and hydrocarbon prospects of the Visayan Basin, Philippines. Geologisches Jahrbuch, Reihe B, 70:1-428.

Potts, D.C. 1983. Evolutionary disequilibrium among Indo-Pacific corals. Bulletin of Marine Science, 33:619-632.

Price, S.A., Wainwright, P.C., Bellwood, D.R., Kazancioglu, E., Collar, D.C., and Near, T.J. 2010. Functional innovations and morphological diversification in parrotfish. Evolution, 64:30573068. https://doi.org/10.1111/j.1558-5646.2010.01036.x

Quelch, J.J. 1884. Preliminary notice of new genera and species of Challenger reef-corals. Journal of Natural History Series 6, 13:292-297. https://doi.org/10.1080/ 00222938409459237

Quelch, J.J. 1886. Report on the reef-corals collected by HMS Challenger during the years 1873-76. Zoology, 16:1-203. https://doi.org/10.5962/bhl.title.11615

R Development Core Team A. 2012. R: A Language and Environment for Statistical Computing. Vienna, Austria, www.R-project.org.

Rachello-Dolmen, P.G. and Cleary, D.F.R. 2007. Relating coral species traits to environmental conditions in the Jakarta Bay/Pulau Seribu reef system, Indonesia. Estuarine, Coastal and Shelf Science, 73:816-826. https://doi.org/10.1016/j.ecss.2007.03.017

Renema, W., Bellwood, D.R., Braga, J.C., Bromfield, K., Hall, R., Johnson, K.G., Lunt, P., Meyer, C.P., McMonagle, L.B., Morley, R.J., O'Dea, A., Todd, J.A., Wesselingh, F.P., Wilson, M.E.J., and Pandolfi, J.M. 2008. Hopping hotspots: Global shifts in marine biodiversity. Science, 321:654-657. https://doi.org/10.1126/science.1155674

Reuss, A.E. 1867. Die Bryozoen, Anthozoen und Spongiaren des braunen Jura von Balin bei Krakau. Denkschriften der Kaiserlichen Akademie der Wissenschaften, 27:1-26.

Roberts, C.M. and Ormond, R.F.G. 1987. Habitat complexity and coral reef fish diversity and abundance on Red Sea fringing reefs. Marine Ecology Progress, Series 41:1-8. https:// doi.org/10.3354/meps041001

Rosen, B.R. 1981. The tropical high diversity enigma-the corals'-eye view, p. 103-129. In Forey, P.L. (ed.), The Evolving Biosphere: Chance, Change and Challenge. Cambridge University Press, Cambridge.

Rosen, B.R. 1984. Reef coral biogeography and climate through the late Cainozoic: just islands in the sun or a critical pattern of islands, p. 201-262. In Brenchley, P.J. (ed.), Fossils and Climate, Geological Journal Special Issue. Wiley, Chichester.

Rosen, B.R. 1985. Review: fact, hypothesis or idea? Journal of Biogeography, 12:383-385. https://doi.org/10.2307/2844871

Rosen, B.R. 1988. Progress, problems and patterns in the biogeography of reef corals and other tropical marine organisms. Helgoländer Meeresuntersuchungen, 42:269-301. https://doi.org/ $10.1007 /$ bf02366046 
Santodomingo, N., Wallace, C.C., and Johnson, K.G. 2015a. Fossils reveal a high diversity of the staghorn coral genera Acropora and Isopora (Scleractinia: Acroporidae) in the Neogene of Indonesia. Zoological Journal of the Linnean Society, 175:677-763. https://doi.org/10.1111/ zoj.12295

Santodomingo, N., Pretković, V., Novak, V., Marshall, N., Di Martino, E., Capelli, E.L.G., Rösler, A., Reich, S., Braga, J.C., Renema, W., and Johnson, K.G. 2015b. A diverse patch reef from turbid habitats in the middle Miocene (East Kalimantan, Indonesia). PALAIOS, 30:128-149. https://doi.org/10.2110/palo.2013.047

Santodomingo, N., Renema, W., and Johnson, K.G. 2016. Understanding the murky history of the Coral Triangle: Miocene corals and reef habitats in East Kalimantan (Indonesia). Coral Reefs, 35:765-781. https://doi.org/10.1007/s00338-016-1427-y

Sasaki, K., Omura, A., Murakami, K., Sagawa, N., and Nakamori, T. 2004. Interstadial coral reef terraces and relative sea-level changes during marine oxygen isotope stages 3-4, Kikai Island, central Ryukyus, Japan. Quaternary International, 120:51-64. https://doi.org/10.1016/ j.quaint.2004.01.006

Scheer, G. 1967. Korallen von den Sarso-Inseln im Roten Meer. Senckenbergiana Biologica, 48:421-436.

Scheer, G. and Pillai, C.G. 1974. Report on Scleractinia from the Nicobar Islands. Zoologica 42:1-75.

Scheer, G. and Pillai, C.G. 1983. Report on the stony corals from the Red Sea. Zoologica, 45:1244.

Simpson, C., Kiessling, W., Mewis, H., Baron Szabo, R.C., and Müller, J. 2011. Evolutionary diversification of reef corals: a comparison of the molecular and fossil records. Evolution, 65:3274-3284. https://doi.org/10.1111/j.1558-5646.2011.01365.x

Simpson, E.H. 1949. Measurement of diversity. Nature, 163:688-688. https://doi.org/10.1038/ $163688 \mathrm{a} 0$

Sommer, B., Harrison, P.L., Beger, M., and Pandolfi, J.M. 2014. Trait-mediated environmental filtering drives assembly at biogeographic transition zones. Ecology, 95:1000-1009. https:// doi.org/10.1890/13-1445.1

Soong, K. 1993. Colony size as a species character in massive reef corals. Coral Reefs, 12:7783. https://doi.org/10.1007/bf00302106

Sorauf, J.E. 1980. Biomineralization, structure and diagenesis of the coelenterate skeleton. Acta Palaeontologica Polonica, 25:327-343.

Stehli, F.G. and Wells, J.W. 1971. Diversity and age patterns in hermatypic corals. Systematic Biology, 20:115-126. https://doi.org/10.2307/2412052

Terraneo, T.I., Berumen, M.L., Arrigoni, R., Waheed, Z., Bouwmeester, J., Caragnano, A., Stefani, F., and Benzoni, F. 2014. Pachyseris inattesa sp. n. (Cnidaria, Anthozoa, Scleractinia): a new reef coral species from the Red Sea and its phylogenetic relationships. ZooKeys, 433:1-30. https://doi.org/10.3897/zookeys.433.8036

Tews, J., Brose, U., Grimm, V., Tielbörger, K., Wichmann, M.C., Schwager, M., and Jeltsch, F. 2004. Animal species diversity driven by habitat heterogeneity/diversity: the importance of keystone structures. Journal of Biogeography, 31:79-92. https://doi.org/10.1046/j.03050270.2003.00994.x

Tokeshi, M. and Arakaki, S. 2011. Habitat complexity in aquatic systems: fractals and beyond. Hydrobiologia, 685:27-47. https://doi.org/10.1007/s10750-011-0832-z

Turak, E., Devantier, L., and Erdmann, M. 2012. Euphyllia baliensis sp. nov. (Cnidaria: Anthozoa: Scleractinia: Euphylliidae): a new species of reef coral from Indonesia. Zootaxa, 3422:52-61. https://doi.org/10.11646/zootaxa.3422.1.3

Umbgrove, J.H.F. 1924. Report on Pleistocene and Pliocene corals from Ceram. Geological, Petrographical and Palaeontological Results of Explorations, Carried out from September till June in the Island of Ceram, Second Series Palaeontology, 1:1-22.

Umbgrove, J.H.F. 1926. Neogene en Pleistoceene Koralen van Sumatra. Wetenschappelijke Mededeelingen, 4:25-56.

Umbgrove, J.H.F. 1929. Anthozoa Van N. O. Borneo. Wetenschappelijke Mededeelingen, 9:4786.

Umbgrove, J.H.F. 1938. Corals from an elevated marl of Talaud (East Indies). Zoologische Mededeelingen, 20:263-274.

Umbgrove, J.H.F. 1939. Miocene corals from Flores (East Indies). Leidsche Geologische Mededeelingeni, 11:62-67. 
Umbgrove, J.H.F. 1942. Corals from asphalt deposits of the island Buton (East Indies). Leidsche Geologische Mededeelingen, 13:29-38.

Umbgrove, J.H.F. 1943. Tertiary corals from Sumba (East Indies). Verhandelingen van het Geologisch-Mijnboowkunding Genootschap voor Nederland en Kolonieni, 13:393-398.

Umbgrove, J.H.F. 1945. Corals from the Upper Miocene of Tjisande, Java. Proceedings of the Royal Society of Amsterdam, 48:340-324.

Umbgrove, J.H.F. 1946a. Corals from the Upper Kalibeng beds (Upper Pliocene) of Java. Proceedings of the Royal Society of Amsterdam, 49:87-93.

Umbgrove, J.H.F. 1946b. Corals from a lower Pliocene patch reef in central Java. Journal of Paleontology, 20:521-542.

Umbgrove, J.H.F. 1946c. Evolution of reef corals in East Indies since Miocene times. Bulletin of the American Association of Petroleum Geologists, 30:23-31. https://doi.org/10.1306/ 3d9337c0-16b1-11d7-8645000102c1865d

Umbgrove, J.H.F. 1950. Corals from the Putjangan beds (lower Pleistocene) of Java. Journal of Paleontology, 24:637-651.

Van der Horst, C.J. 1922. The Percy Sladen Trust Expedition to the Indian Ocean in 1905. IX Madreporaria Agariciidae. Transactions of the Linnean Society, Zoology (Ser. 2), 18:417-429.

Vaughan, T.W. and Wells, J.W. 1943. Revision of the suborders, families and genera of the Scleractinia. Geological Society of America, 44:1-363. https://doi.org/10.1130/spe44-p1

Veron, J.E.N. 1986. Corals of Australia and the Indo-Pacific. Angus and Robertson Publishers, London.

Veron, J.E.N. 1995. Corals in Space and Time: The Biogeography and Evolution of the Scleractinia. UNSW Press, Townsville.

Veron, J.E.N. 2000. Corals of the World. Australian Institute of Marine Sciences, Townsville.

Veron, J.E.N. 2002. New species described in corals of the World. Australian Institute of Marine Science Monograph Series, 11:1-207.

Veron, J.E.N., DeVantier, L.M., Turak, E., Green, A.L., Kininmonth, S., Stafford-Smith, M., and Peterson, N. 2009. Delineating the Coral Triangle. Galaxea, Journal of Coral Reef Studies, 11:91-100. https://doi.org/10.3755/galaxea.11.91

Veron, J.E.N. and Kelly, R. 1998. Coral species stability in reef corals of Papua New Guinea and the Indo-Pacific. Memoir of the Association of Australasian Palaeontologists, 6:1-69.

Veron, J.E.N. and Pichon, M. 1976. Scleractinia of Eastern Australia: Part 1. Australian Government Publishing Service, Canberra.

Veron, J.E.N. and Pichon, M. 1980. Scleractinia of Eastern Australia: Part 3. Australian Institute of Marine Sciences, Canberra.

Veron, J.E.N. and Pichon, M. 1982. Scleractinia of Eastern Australia: Part 4. Australian Institute of Marine Sciences, Canberra.

Veron, J.E.N., Pichon, M., and Wijsman-Best, M. 1977. Scleractinia of Eastern Australia: Part 2. Australian Government Publishing Service, Canberra.

Veron, J.E.N. and Stafford-Smith, M. 2002. Coral ID (first release 2002). Australian Institute of Marine Science, Townsville, CD-ROM.

Veron, J.E.N. and Wallace, C.C. 1984. Scleractinia of Eastern Australia: Part 5. Australian Institute of Marine Sciences, Canberra.

Verrill, A.E. 1864. List of the polyps and corals sent by the Museum of Comparative Zoology to other institutions in exchange, with annotations. Bulletin of the Museum of Comparative Zoology, 1:29-60.

Verrill, A.E. 1866. Synopsis of the polyps and corals of the North Pacific Exploring Expedition, 1853-1856, with descriptions of some additional species from the West Coast of North America. III Madreporaria. Salem: Communications of the Essex Institute, 5:17-50.

Verrill, A.E. 1901. Variations and Nomenclature of Bermudian, West Indian, and Brazilian Reef Corals: With Notes on Various Indo-Pacific Corals. Comparisons of the Bermudian, West Indian, and Brazilian Coral Faunae. Connecticut Academy of Sciences, New Haven.

Vredenburg, E. 1921. Comparative diagnoses of Pleurotomidae from the Tertiary formations of Burma. Geological Survey of India, Records, 53:83-141.

Wallace, C.C. 1997. The Indo-Pacific centre of coral diversity re-examined at species level, $p$. 365-370. In Lessios. H.A. and Macintyre, I.G. (eds.), Proceedings of the 8th International Coral Reef Symposium Vol. 1. Smithsonian Tropical Research Institute, Panama.

Wallace, C.C. 1999. Staghorn Corals of the World: A Revision of the Genus Acropora. CSIRO Publishing, Collingwood. 
Wallace, C.C., Fellegara, I., Muir, P.R., and Harrison, P.L. 2009. The scleractinian corals of Moreton Bay, eastern Australia: high latitude, marginal assemblages with increasing species richness. Memoirs of the Queensland Museum, 54:1-118.

Wallace, C.C. and Rosen, B.R. 2006. Diverse staghorn corals (Acropora) in high-latitude Eocene assemblages: implications for the evolution of modern diversity patterns of reef corals. Proceedings of the Royal Society B: Biological Sciences, 273:975-982. https://doi.org/ 10.1098/rspb.2005.3307

Wallace, C.C., Turak, E., and Devantier, L. 2011. Novel characters in a conservative coral genus: three new species of Astreopora (Scleractinia: Acroporidae) from West Papua. Journal of Natural History, 45:1905-1924. https://doi.org/10.1080/00222933.2011.573098

Wannier, M. 2009. Carbonate platforms in wedge-top basins: An example from the Gunung Mulu National Park, Northern Sarawak (Malaysia). Marine and Petroleum Geology, 26:177-207. https://doi.org/10.1016/j.marpetgeo.2007.12.004

Wells, J.W. 1936. The madreporarian genus Polyastra Ehrenberg. Journal of Natural History, 18:549-552.

Wells, J.W. 1954. Recent Corals of the Marshall Islands: An Ecologic and Taxonomic Analysis of Living Reef-and Non-reef-building Corals at Bikini and Other Marshall Islands Atolls. U.S. Government Printing Office, Washington D.C.

Wells, J.W. 1964. Fossil Corals from Eniwetok Atoll. U.S. Government Printing Office, Washington D.C.

Wilson, M.E.J. 2008. Global and regional influences on equatorial shallow-marine carbonates during the Cenozoic. Palaeogeography, Palaeoclimatology, Palaeoecology, 265:262-274. https://doi.org/10.1016/j.palaeo.2008.05.012

Wilson, M.E.J. and Rosen, B.R. 1998. Implications of paucity of corals in the Paleogene of SE Asia: plate tectonics or centre of origin, p. 165-195. In Hall, R. and Holloway, J.D. (eds.), Biogeography and Geological Evolution of SE Asia. Backhuys Publishers, Leiden. 


\section{APPENDIX 1.}

Oligocene-Miocene scleractinians from Malaysian Borneo and the Philippines - speciment list (available in PDF format at https://palaeo-electronica.org/content/2019/2715-oligocene-miocene-corals). 